\title{
COMPORTAMENTO IN VITRO DE EXPLANTES DE MATRIZES DE CENOURA (Daucus carota L.) TRATADAS COM VARIÁVEIS NÍVEIS DE POTÁSSIO
}

\section{ANTONIO FRANCISCO DE CAMPOS AMARAL}

\begin{abstract}
Dissertação apresentada à Escola Superior de Agricultura "Luiz de Queiroz", Universidade de São Paulo, para obtenção do título de Mestre em Ciências, Área de Concentração: Fisiologia e Bioquímica de Plantas.
\end{abstract}

\author{
P I R A C I C A B A \\ Estado de São Paulo - Brasil \\ Maio - 2003
}




\title{
COMPORTAMENTO IN VITRO DE EXPLANTES DE MATRIZES DE CENOURA (Daucus carota L.) TRATADAS COM VARIÁVEIS NÍVEIS DE POTÁSSIO
}

\section{ANTONIO FRANCISCO DE CAMPOS AMARAL \\ Farmacêutico}

Orientador: Prof. Dr. MURILO DE MELO

Dissertação apresentada à Escola Superior de Agricultura "Luiz de Queiroz", Universidade de São Paulo, para obtenção do título de Mestre em Ciências, Área de Concentração: Fisiologia e Bioquímica de Plantas.

\author{
P I R A C I C A B A \\ Estado de São Paulo - Brasil \\ Maio - 2003
}




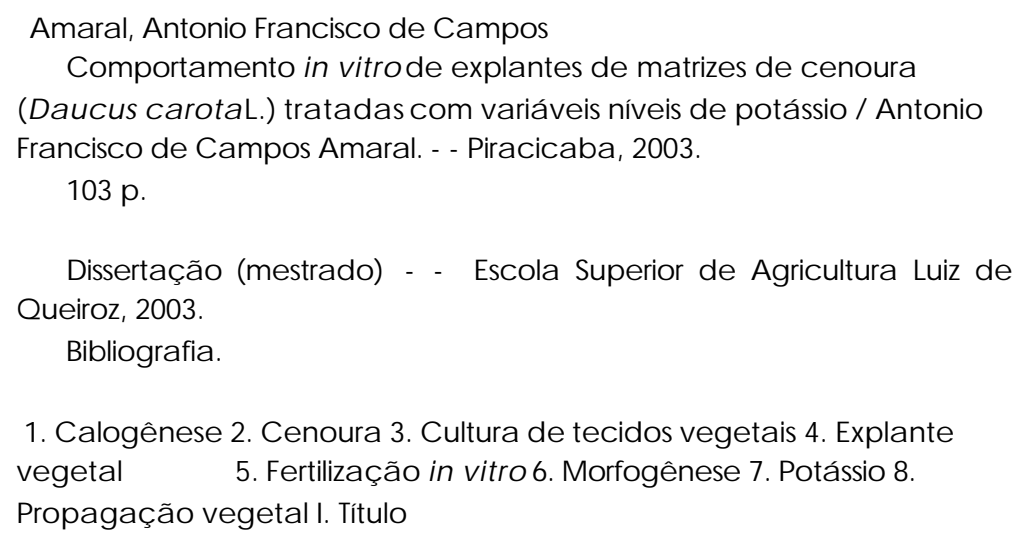

1. Calogênese 2. Cenoura 3. Cultura de tecidosvegetais 4. Explante vegetal 5. Fertilização in vitro 6. Morfogênese 7. Potássio 8.

Propagação vegetal I. Título 
À Deus pela saúde
e por sua grandeza;

Aos meus pais Dico e Dirce, pelo apoio e incentivo,

OFEREÇO.
Ao meu amigo, Murilo de Melo pela ajuda $e$ incentivo recebidos sempre,

DEDICO. 


\section{AGRADECIMENTOS}

Agradeço a todas as pessoas que, de forma direta ou indireta, contribuíram para a realização deste trabalho, especialmente:

Ao Prof. Dr. Murilo de Melo pela orientação, amizade e incentivo durante a realização deste trabalho.

Às amigas Ana Lúcia Decico e Márcia O. Mello pela amizade e ajuda na realização deste trabalho.

Ao Prof. Dr. Otto J. Crocomo, do Departamento de Ciências Biológicas - CEBTEC pelo apoio, incentivo, amizade e sobretudo por conceder o laboratório na realização deste trabalho.

Ao Prof. Dr. Luiz Antonio Gallo, do Departamento de Ciências Biológicas pelo apoio, incentivo e amizade.

À Profa. Dra. Helaine Carrer, do Departamento de Ciências Biológicas pelo apoio e amizade.

Ao Prof. Dr. Ricardo A. Klüge do Departamento de Ciências Biológicas pela ajuda e amizade. 
Ao Prof. Dr. Quirino Augusto de Camargo Carmello, pela elaboração da composição química das soluções nutritivas utilizadas neste trabalho.

À Profa. Dra. Sônia Maria de Sthephano Piedade do Departamento de Ciências Exatas, pela atenção e elaboração das análises estatísticas deste trabalho.

Às amigas do Curso de Fisiologia e Bioquímica de Plantas: Rosana, Liliane, Carolina, Amanda, Joana e Marisa.

À minha irmã Nancy pela amizade e ajuda.

Aos colegas do Laboratório do Centro de Biotecnologia Agrícola CEBTEC, pela amizade, em todos os momentos.

A todos os professores, alunos e funcionários do Departamento de Ciências Biológicas da ESALQ/USP, que de alguma forma colaboraram para a realização deste trabalho.

Aos funcionários do Setor de Biblioteca Central da ESALQ/USP, pelos auxílios prestados. 


\section{SUMÁRIO}

Página

LISTA DE ABREVIATURAS........................................................... viii

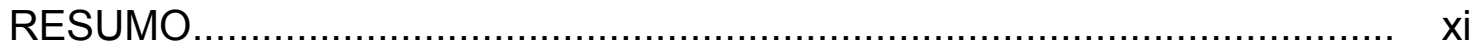

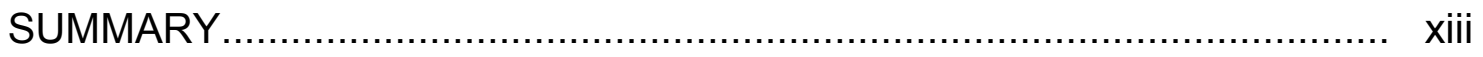

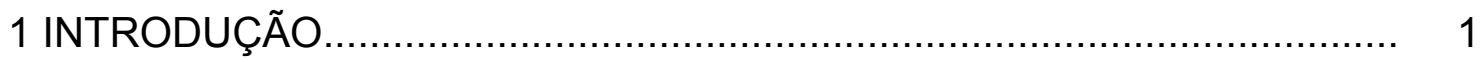

2 REVISÃO DE LITERATURA................................................................ 3

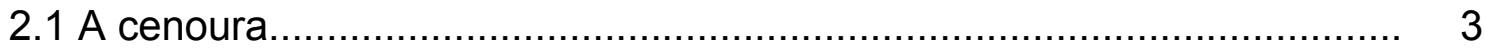

2.2 Nutrição mineral de plantas.............................................................. 4

2.2.1 Nutrientes minerais............................................................... 7

2.2.2 Cátions $\left(\mathrm{Mg}^{2+}, \mathrm{Ca}^{2+}\right.$ e $\left.\mathrm{K}^{+}\right)$no metabolismo celular de plantas............. 12

2.2.2.1 Magnésio............................................................................ 12

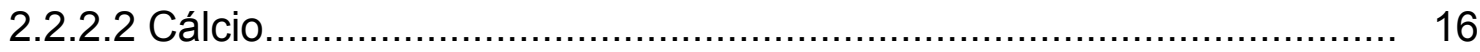

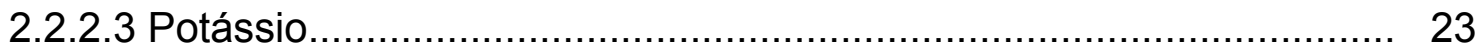

2.3 Cultura de tecidos de plantas...................................................... 29

2.3.1 Fatores que afetam a morfogênese in vitro...................................... 31

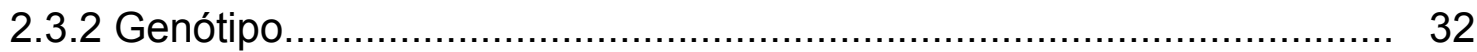

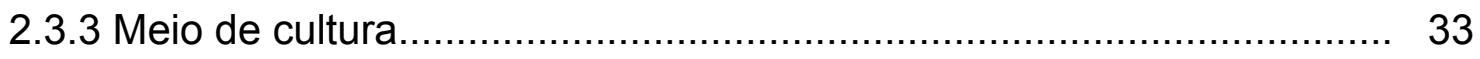

2.3.4 Condições ambientais............................................................... 34

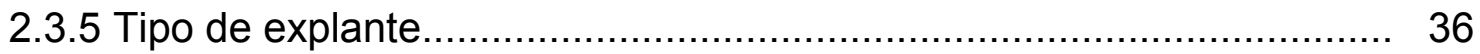

2.3.6 Padrões morfogênicos de diferenciação celular que ocorrem

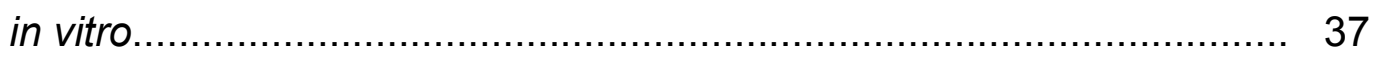

2.3.7 Manejo da planta matriz........................................................... 38

3 MATERIAL E MÉTODOS .............................................................. 40 
3.1 Obtenção de plantas matrizes com diferentes estados nutricionais....... 40

3.2 Estabelecimento da cultura de calos................................................... 42

3.2.1 Assepsia dos explantes............................................................ 42

3.2.2 Calogênese.................................................................... 42

3.2.3 Diferenciação celular.................................................................. 43

3.4 Análise química das plantas ......................................................... 43

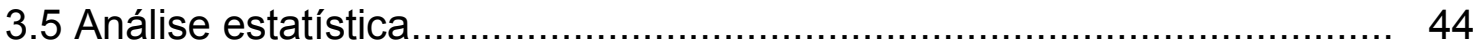

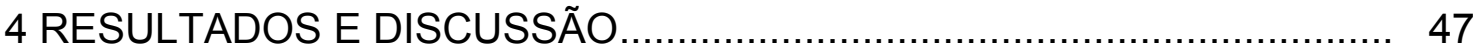

4.1 Desenvolvimento das plantas matrizes........................................... 47

4.2 Calogênese

4.3 Diferenciação celular.................................................................. 61

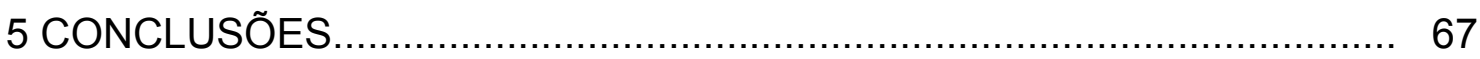

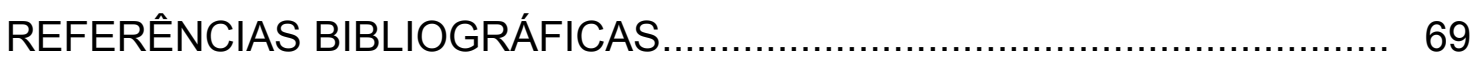

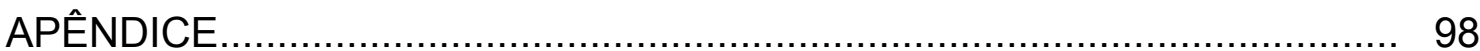




\section{LISTA DE ABREVIATURAS}

${ }^{0} \mathrm{C}=$ grau centígrado

2,4-D = ácido 2,4-dicloro fenoxiacético

$\mathrm{ABA}=$ ácido abscísico

$\mathrm{ADP}=$ adenosina difosfato

AIA = ácido indolilacético

ATP $=$ adenosina trifosfato

ATPase = enzima adenosina trifosfatase

$\mathrm{BA}=$ benziladenina

$\mathrm{BAP}=$ benzil amino-purina

$\mathrm{Ca}^{2+}=$ íon cálcio

$\mathrm{CaCl}_{2}=$ cloreto de cálcio

$\mathrm{CAM}=$ calmodulinas

$\mathrm{cm}=$ centímetro

$\mathrm{CO}_{2}=$ dióxido de carbono

$D A G=$ diacilglicerol

$\mathrm{GA}=$ ácido giberélico

$\mathrm{H}^{+}=$íon hidrogênio

$\mathrm{HCl}=$ ácido clorídrico

$\mathrm{H}_{2} \mathrm{O}_{2}$ = peróxido de hidrogênio

$\mathrm{IP}_{3}=$ inositol 1,4,5-trifosfato

$\mathrm{K}^{+}=$íon potássio 


$$
\begin{aligned}
& \mathrm{Km}=\text { constante de Michaelis } \\
& \mathrm{KNO}_{3}=\text { nitrato de potássio } \\
& \mathrm{KOH}=\text { hidróxido de potássio } \\
& \mathrm{L}=\text { litro } \\
& \mathrm{mg}=\text { miligrama } \\
& \mathrm{Mg}^{2+}=\text { íon magnesio } \\
& \mathrm{MgSO}_{4}=\text { sulfato de magnésio } \\
& \mathrm{mL}=\text { mililitro } \\
& \mathrm{MMF}=\text { massa de matéria fresca } \\
& \mathrm{mM}=\text { milimolar } \\
& \mathrm{mmol} . \mathrm{L}^{-1}=\text { milimol por litro } \\
& \text { MMS = massa de matéria seca } \\
& \mathrm{Mn}^{+2}=\text { íon manganês } \\
& \text { MS = Meio formulado por Murashige \& Skoog (1962) } \\
& \mathrm{N}=\text { normal } \\
& \mathrm{N}_{2}=\text { nitrogênio } \\
& \mathrm{Na}^{+}=\text {íon sódio } \\
& \mathrm{Na}_{2}-\text { EDTA = etilenodiaminotetraacetato de sódio } \\
& N A D=\text { nicotinamida adenina dinucleotideo } \\
& \text { NADP = nicotinamida adenina dinucleotideo fosfato } \\
& \mathrm{NH}_{4}{ }^{+}=\text {íon amônio } \\
& \mathrm{nm}=\text { nanômetro } \\
& \mathrm{PEP}=\text { fosfoenol piruvato } \\
& \mathrm{Pi}=\text { fósforo inorgânico } \\
& \text { PIP = fosfatidinositol-4, 5-bifosfato } \\
& \mathrm{PLC}=\text { fosfolipase }-\mathrm{C} \\
& \mathrm{RE}=\text { retículo endoplasmático } \\
& \text { RNA = ácido ribonucléico } \\
& \text { tRNA = ácido ribonucléico transportador }
\end{aligned}
$$




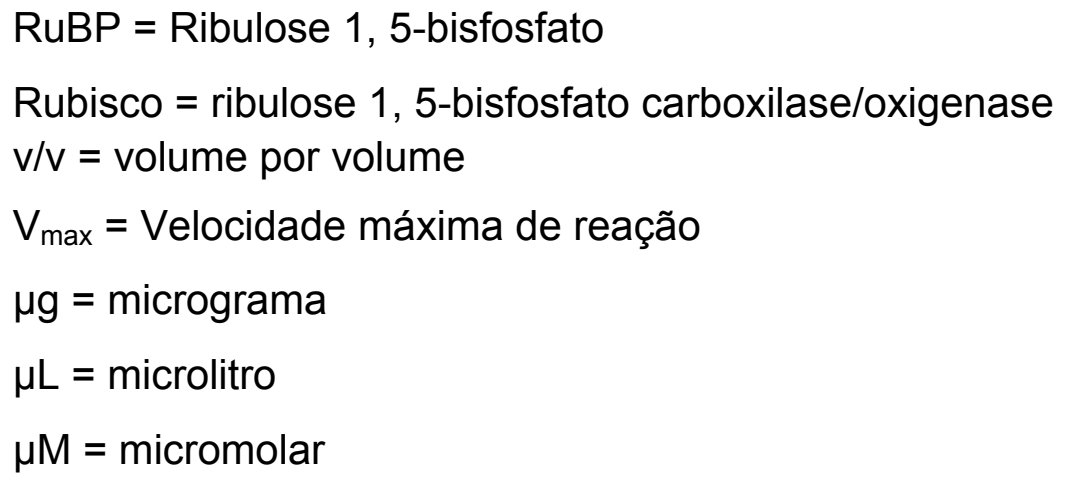




\title{
COMPORTAMENTO IN VITRO DE EXPLANTES DE MATRIZES DE CENOURA (Daucus carota L.) TRATADAS COM VARIÁVEIS NÍVEIS DE POTÁSSIO
}

\author{
Autor: ANTONIO FRANCISCO DE CAMPOS AMARAL \\ Orientador: Prof. Dr. MURILO DE MELO
}

\section{RESUMO}

O crescimento de plantas, órgãos, tecidos e células in vitro depende do desenvolvimento de meios de cultura otimizados para a perfeita interação de componentes essenciais como fitorreguladores, fonte de carbono e nutrientes minerais. Os fatores que limitam o crescimento de órgãos ou tecido in vitro são similares a aqueles que limitam o crescimento in vivo. Com o objetivo de testar a influência do estado nutricional de plantas matrizes de cenoura Daucus carota Link em potássio na morfogênese in vitro, plantas obtidas de sementes germinadas em substrato e cultivadas em vasos com areia em condições de casa de vegetação, foram submetidas a tratamentos com soluções nutritivas contendo variáveis níveis de potássio. Decorridos 30 e 60 dias de tratamento, explantes dessas plantas (internódios) foram coletados, desinfetados e inoculados em meio de cultura sólido de MS contendo também diferentes concentrações de potássio e acrescido de $0,1 \mathrm{mg} \cdot \mathrm{L}^{-1}$ da auxina 2,4-D buscando indução de calogênese na ausência de luz. Diferenciação celular via 
embriogênese somática foi conseguida em ausência de auxina em condições de fotoperíodo de 16/8 horas (claro/escuro). A avaliação da calogênese foi feita aos 60 dias após a inoculação, com base na massa de matéria fresca e seca dos calos formados por explante. A avaliação da diferenciação celular (número de plantas/explante) e taxa de diferenciação celular (número de plantas/g de matéria seca de calos) foi realizada após 30 dias de cultivo em condições de luz. A indução de calogênese e crescimento celular nos explantes de matrizes tratadas foi influenciada pelo tratamento pelos níveis de $\mathrm{K}^{+}$na solução nutritiva e pela duração dos tratamentos. Explantes de matrizes tratadas com alta concentração de $\mathrm{K}^{+}$resultaram em indução e crescimento de calos em matéria fresca e seca inversamente proporcional à concentração de $\mathrm{K}^{+}$no meio de cultura tanto para tratamento por 30 dias como para 60 dias. Tratamentos de curta duração (30 dias) com altos níveis de $\mathrm{K}^{+}$nas soluções nutritivas e baixos níveis de $\mathrm{K}^{+}$no meio de cultura influenciaram negativamente a regeneração de plantas ( $n^{\circ}$ plantas/explante) nos calos dos explantes das matrizes tratadas. No entanto, taxas mais altas de diferenciação celular ( $\mathrm{n}^{\circ}$ plantas $/ \mathrm{g}$ de matéria seca de calos) ocorreram nos calos de explantes de matrizes tratadas por 30 dias com solução nutritiva contendo maiores níveis de potássio e inoculados em meio de cultura contendo concentrações iguais ou maiores de que a do meio MS. 


\title{
IN VITRO BEHAVIOUR OF EXPLANTS FROM POTASSIUM TREATED CARROT MATRIXES (Daucus carota L.)
}

\author{
Author: ANTONIO FRANCISCO DE CAMPOS AMARAL \\ Adviser: Prof. Dr. MURILO DE MELO
}

\section{SUMMARY}

The growth of plants, organs, tissues and cells in vitro culture depends on the development of optimized culture medium for the perfect interaction among essential components such as phytoregulators, carbon source and minerals nutrients. The factors limiting the growth of organs or tissues in vitro conditions are similar to those limiting growth in vivo conditions. The objective of this work was aimed at studying the influence of the potassium nutritional status of matrixes plants of carrot Daucus carota Link on the in vitro morphogenesis. Matrixes plants were obtained from seeds germinated in organic substratum and cultivated in plastic pots containing washed sand in greenhouse conditions. The matrixes plants were then submitted to treatments with nutrients solutions containing variable potassium levels. After 30 and 60 days treatment, explants (internodes) were collected, disinfested and inoculated in solid culture medium of Murashige and Skoog (MS) containing different potassium concentrations and supplemented with $0,1 \mathrm{mg} \cdot \mathrm{L}^{-1}$ of $2,4-\mathrm{D}$ for callogenesis induction in dark conditions. Cell differentiation by somatic embryogenesis was pursued by 
culturing the calli in auxina-free same culture medium in growth room under photoperiod of 16/8 hours (light/dark). The evaluation of the callogenesis induction and cell growth was carried out 60 days after explants inoculation, based on the mass of fresh and dry matter accumulation on each explant. The evaluation of cell differentiation (plant formed/explant) and of cell differentiation rate (number of plants formed/g of dry matter of callus) was carried after 30 days of culturing under light conditions. Callogenesis induction and cell growth on the explants of treated matrixes plants were affected by the potassium treatment levels in the nutrient solution and by the duration of the treatments. Explants from treated plants with the higher $\mathrm{K}^{+}$concentrations showed callus induction and growth inversely proportional to the concentration of $\mathrm{K}^{+}$in the culture medium for both (30 and 60 days) treatment duration. However the callogenesis accumulated after 60 days treatment was twice as much as that of 30 days treatments. Short time treatments duration (30 days) with higher levels of $\mathrm{K}^{+}$in the nutrient solutions and low concentrations of $\mathrm{K}^{+}$in the culture medium influenced the cell differentiation negatively ( $n^{\circ}$ plants/explant) in the callus of the explants from treated plants. Cells from calli induced on explants from matrixes plants for 30 days were more morphogenic than the cells in the 60 days treatment where high callogenesis was observed. Also better cell differentiation rate was observed on calli induced on explants from treated matrixes plants with nutrient solutions containing the highest potassium levels and inoculated on MS culture medium containing highest potassium concentrations. 


\section{INTRODUÇÃO}

A cenoura, Daucus carota L., pertencente à família Umbelliferae, é uma planta cultivada sob clima fresco e sua raiz é fonte de alimento em todas as partes do mundo. Aproximadamente 80 espécies do gênero Daucus têm sido descritas, metade das quais são subespécies ou formas da espécie $D$. carota (Ammirato, 1983b). Segundo Barbedo et al. (2000), a cenoura é uma importante hortaliça no Brasil e diversos cultivares aqui utilizados foram obtidas do melhoramento vegetal realizado em outros países e, dentre estas, muitas até hoje, necessitam que suas sementes sejam importadas.

Através das técnicas de cultura de tecidos tem-se conseguido a propagação de muitas espécies a partir de partes da planta, como por exemplo: (a) utilização de ápices e meristemas quando se deseja fazer micropropagação e limpeza de vírus respectivamente; (b) utilização de segmentos vegetais para regeneração de plantas via organogênese ou embriogênese somática; (c) cultura de protoplastos para transformação de plantas; (d) cultura de células em suspensão para produção de metabólitos químicos, especialmente substâncias medicinais.

$\mathrm{Na}$ cultura de tecidos, o controle da morfogênese é feito através da introdução de sinais (estímulos) exógenos e/ou substratos, porém explantes de mesma natureza retirados de plantas em diferentes condições fisiológicas podem apresentar respostas bastante distintas (Torres \& Caldas, 1990).

Segundo Grattapaglia \& Machado (1990), o sucesso de um sistema de micropropagação depende do controle de um grande número de variáveis. George \& Sherrington (1984) afirmam que os fatores que afetam o crescimento 
e morfogênese in vitro podem ser: genótipo, meio de cultura, condições de cultivo e fatores do tecido, sendo que neste último, a maneira em que a planta matriz tem sido cultivada pode influenciar de maneira bastante acentuada no posterior início e desenvolvimento da cultura.

Alguns autores estudaram o efeito da composição do meio de cultura no crescimento de cenoura, como fontes de nitrogênio (Halperin \& Wetherel, 1965) de diferentes concentrações de carboidratos (Verma \& Dougall, 1977) e de reguladores vegetais (Sussex \& Frei, 1968).

Kessel \& Carr (1972) mostraram que a concentração de oxigênio influencia severamente a subseqüente morfogênese e Halperin (1967) relatou o efeito da densidade das células embriogênicas e maturação dos embriões em cenoura.

Existem alguns trabalhos que relatam as técnicas da cultura de células ou tecidos, apresentando protocolo de cultivo para inúmeras espécies, porém são escassos os trabalhos que levam em consideração o nível de nutrientes que deve estar contido no meio de cultura para a maximização da calogênese. Trabalhos que venham a considerar o efeito do estado nutricional de plantas matrizes na calogênese induzida nos explantes destas matrizes são ainda mais escassos.

Nesta dissertação estão sendo apresentados os resultados do efeito de tratamentos de plantas matrizes de cenoura no comportamento in vitro (calogênese e diferenciação celular) de explantes extraídos destas matrizes. 


\section{REVISÃO DE LITERATURA}

\subsection{A cenoura}

A cenoura tem importância pela sua estrutura suculenta subterrânea consistindo basicamente da base dilatada da raiz principal e parcialmente derivada do hipocótilo. A espécie, D. carota, é nativa do oeste da Ásia, provavelmente do Afeganistão. Cenouras foram primeiro usadas com propósitos medicinais e gradualmente adaptadas como alimento (Shannon \& Grieve, 1999).

Em todo o mundo, a produção de cenoura tem aumentado constantemente desde 1960 (Ammirato, 1983b). Entre as cultivares nacionais, a variedade Brasília, tem grande potencial comercial (Barbedo et. al, 2000). São excelentes fontes de beta-caroteno, também chamadas pró-vitamina $A$, que pode ser convertido para vitamina A (Banga, 1976). Existem também consideráveis quantidades de vitaminas $B_{1}$ e $C$ e um óleo essencial, rico em vitamina E. Cenouras também possuem altos teores de carboidratos, mas baixos em proteínas e lipídeos (Harbone, 1971).

Segundo Ammirato (1983b), trabalhos científicos sobre melhoramento genético de cenoura nos centros de pesquisa não medem esforços para entender a esterilidade (macho) e sua subseqüente manipulação para produzir semente $F_{1}$ para cultivo comercial. A cenoura é uma cultura de várias espécies de polinização cruzada, e então a propagação in vitro poderia ser de grande valor para multiplicar e manter variedades congênitas futuras como os pais, na produção de semente híbrida $\mathrm{F}_{1}$, com o objetivo de melhorar a produção in vivo. 
Segundo Betti (1991), a cultura de meristema in vitro é a maneira mais segura e eficiente de se obter mudas isentas de vírus, sendo a propagação por meio de cultura de tecidos uma maneira de produzir plantas livres de patógenos e viroses (Ahmed \& Andrea, 1987). Também o modelo de comportamento de explantes de cenoura no que diz respeito a diferenciação celular (embriogênese somática) é considerada padrão entre as plantas estudadas in vitro (Ammirato, 1983b).

\subsection{Nutrição mineral de plantas}

As altas taxas de absorção de nutrientes na região apical da raiz resultam da forte demanda dos nutrientes nestes tecidos e da disponibilidade dos nutrientes no solo ao seu redor. Por exemplo, a elongação celular depende do acúmulo de solutos como o potássio e nitrato para aumentar a pressão osmótica intracelular. O amônio é a fonte de nitrogênio preferida para sustentar a divisão celular do meristema, porque tecidos meristemáticos são freqüentemente pobres em carboidratos e a assimilação de amônio consome menos energia do que de nitrato.

No solo os nutrientes podem mover-se para a superfície da raiz por fluxo contínuo ou difusão. No fluxo contínuo os nutrientes são carregados pela água movendo através do solo até as raízes. A quantidade de nutriente proporcionada para a raiz pelo fluxo contínuo depende da taxa de fluxo de água através do solo até a planta, a qual depende das taxas de transpiração e da concentração de nutriente na solução do solo. $\mathrm{Na}$ difusão os nutrientes minerais movem-se através de gradiente de concentração, ou seja, de uma região de maior para outra de menor concentração em volta da raiz.

Por outro lado, a absorção dos íons minerais depende muito da

afinidade do nutriente com o mecanismo de absorção da raiz (Mengel \& Kirkby, 1987). Portanto, tanto na solução do solo como nas soluções nutritivas e em meios de cultura os sais de $\mathrm{KNO}_{3}, \mathrm{CaCl}_{2}$ e $\mathrm{MgSO}_{4}$ são primeiros ionizados para 
em seguida serem absorvidos pela raiz da planta através das membranas celulares por transportadores específicos.

Nutrientes minerais absorvidos pela raiz são transportados até as regiões de crescimento pelo fluxo de transpiração através do xilema. Em termos de translocação e transporte de pequenas moléculas, a parede celular contém aberturas de polissacarídeos por onde passam facilmente os nutrientes, como acontece com os íons minerais da superfície das raízes até o córtex e em seguida para dentro do xilema. Da epiderme até os vasos de xilema da raiz, existem três possíveis caminhos através das quais a água pode fluir carregando os íons minerais: (1) movimento apoplástico, ocorre via paredes celulares; (2) movimento simplástico ocorre de protoplastos a protoplastos via plasmodesmos e (3) via transcelular quando ocorre de célula a célula e a água passa de um vacúolo a outro.

Os cátions absorvidos pelas células vegetais formam complexos com componentes orgânicos os quais se unem por ligações eletrovalentes. Macronutrientes como o potássio, magnésio e cálcio, bem como os micronutrientes cobre, ferro, manganês, cobalto, sódio e zinco encontram-se nas células dessa maneira. Na formação de complexos coordenados, átomos de oxigênio ou nitrogênio de um composto de carbono doam elétrons não compartilhados para formar ligação com um cátion. Como resultado, a carga positiva do cátion é neutralizada. Complexos coordenados, tipicamente, formam-se entre cátions polivalentes e moléculas orgânicas, tais como o cobre no ácido tartárico (Figura 1a) ou magnésio na molécula de clorofila a (Figura 1b). Neste último o $\mathrm{Mg}^{2+}$ é unido por ligações coordenadas com os átomos de nitrogênio no anel de porfirina. Os nutrientes que são assimilados nos complexos coordenados incluem o cobre, zinco, ferro, potássio, cálcio e magnésio. $O$ cálcio pode formar também o complexo com 0 ácido poligalacturônico das paredes celulares (Figura 1c). 
(A)

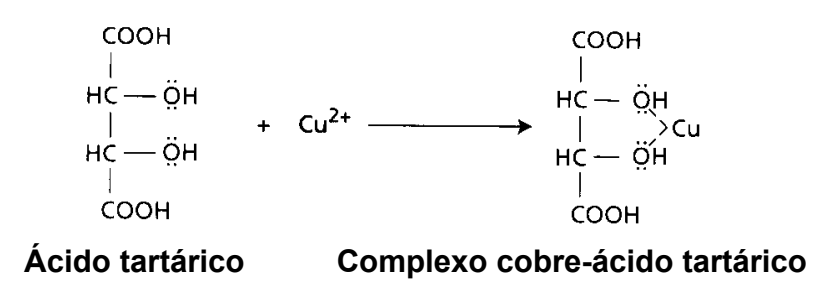

(B) $\mathrm{H}_{2} \mathrm{C}=\mathrm{CH}$

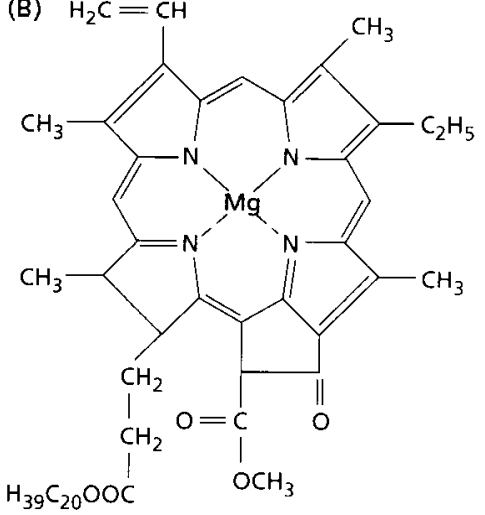

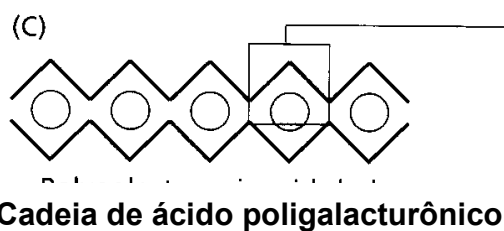

Cadeia de ácido poligalacturônico

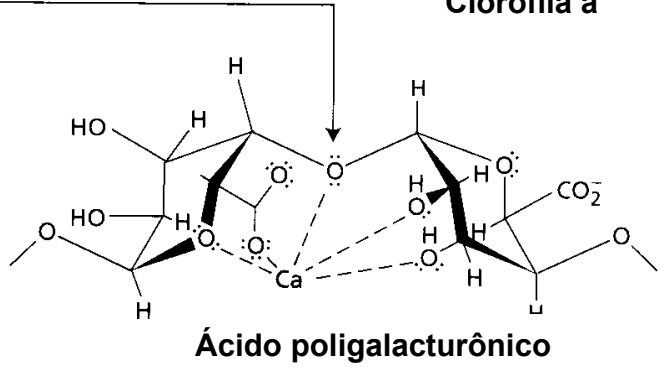

Figura 1- Exemplos de complexos de coordenação. Estes complexos formamse quando átomos de nitrogênio ou oxigênio do componente orgânico doa elétrons não compartilhados (representado por linhas pontilhadas) para formar ligação com cátion. (A) ĺon cobre compartilham elétrons com os oxigênios da hidroxila do ácido tartárico. (B). Íons magnésio compartilham elétrons com átomos de nitrogênio na clorofila a . (C) Modelo da interação do ácido poligalacturônico e íons cálcio. A maior parte do cálcio na parede celular parece ser ligada desta maneira

Ligações eletrostáticas se formam pela atração de um cátion carregado positivamente por um grupo do composto orgânico carregado negativamente. Um grupo importante carregado negativamente é a forma ionizada do ácido carboxílico $\left(-\mathrm{COO}^{-}\right)$. Os cátions monovalentes tal como o potássio $\left(\mathrm{K}^{+}\right)$pode formar ligações eletrostáticas com os grupos carboxílicos de muitos ácidos 
orgânicos (Figura 2a). Entretanto, a maior parte do potássio acumulado pelas células vegetais, que funciona na regulação osmótica e ativação de enzimas, permanece no citossol e no vacúolo como íon livre. Os íons bivalentes tais como o cálcio forma ligações eletrostáticas com substâncias pécticas (Figura 2b) e com os grupos carboxílicos do ácido poligalacturônico.

No geral, os cátions como magnésio $\left(\mathrm{Mg}^{2+}\right)$, cálcio $\left(\mathrm{Ca}^{2+}\right)$ e potássio $\left(\mathrm{K}^{+}\right)$são assimilados tanto na formação dos complexos coordenados como nas ligações eletrostáticas com os aminoácidos, fosfolipídios e outras moléculas carregadas negativamente.
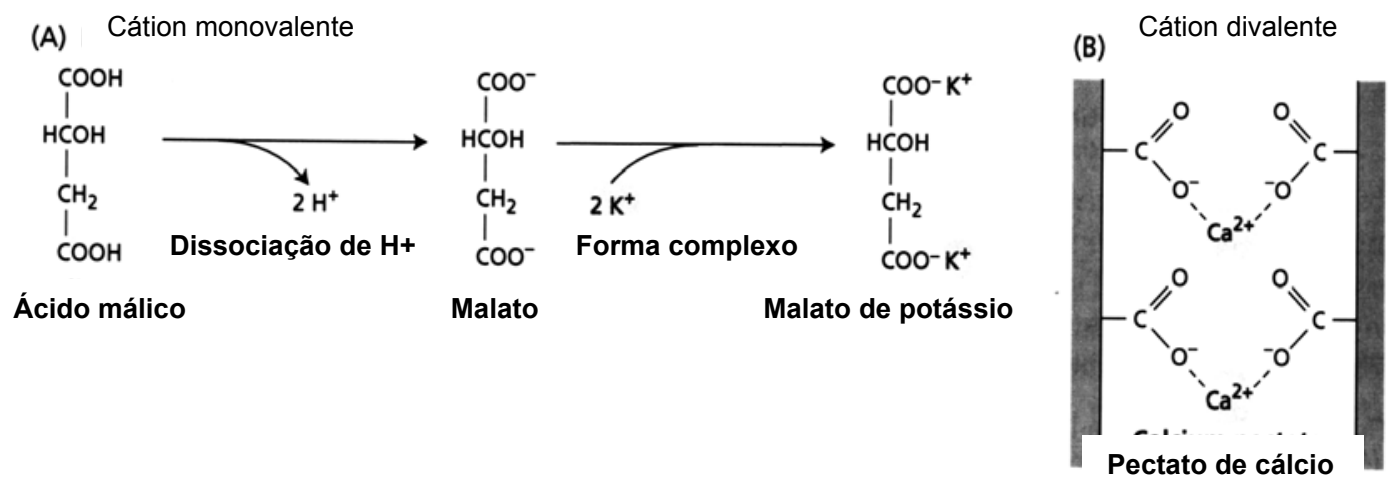

Figura 2 - Exemplos de complexos (iônicos) eletrostáticos. (A) o cátion monovalente $\mathrm{K}^{+}$e malato formam o complexo malato de potássio. (B) $\mathrm{O}$ cátion divalente $\mathrm{Ca}^{2+}$ e pectato formam o complexo pectato de cálcio. Cátions divalentes podem formar ligações cruzadas entre as fitas paralelas que contem grupos carboxílicos carregados negativamente. As ligações cruzadas de cálcio têm papel estrutural nas paredes celulares

\subsubsection{Nutrientes essenciais}

Os elementos minerais essenciais são atualmente classificados como macronutrientes ou micronutrientes, de acordo com sua concentração relativa no 
tecido da planta. Muitos elementos podem estar presentes em concentrações maiores do que as necessidades mínimas da planta. Apenas alguns elementos são essenciais ao crescimento vegetal. Um elemento essencial apresenta papel fisiológico bem definido e na sua ausência impede a planta de completar seu ciclo de vida (Arnon \& Stout, 1939). As plantas através da energia da luz solar, quando fornecidos todos os nutrientes minerais, podem sintetizar todos os compostos que precisam para seu crescimento normal como mostrado de maneira resumida na Tabela 1.

Alguns pesquisadores como Mengel \& Kirkby (1987) têm proposto que os elementos essenciais sejam classificados de acordo com seu papel bioquímico e função biológica, conforme ilustrado na Tabela 1. 
Tabela 1. Classificação dos nutrientes minerais de acordo com a função bioquímica

Elemento Funções

Grupo 1 Nutrientes que formam os compostos orgânicos das plantas

Nitrogênio Constituinte de aminoácidos, amidas, proteínas, ácidos nucléicos, nucleotidios, coenzimas, hexoaminas, etc.

Enxofre Componente da cisteina, cistina, metionina e proteínas. Constituinte da coenzima A, tiamina pirofosfato, biotina, etc.

Grupo 2 Nutrientes que são importantes no estoque de energia ou integridade estrutural

Fósforo Componente de açúcares fosfato, ácidos nucléicos, nucleotidios, coenzimas, fosfolipídios, etc. Importante nas reações nas quais envolvem ATP.

Boro Forma complexos com manitol, ácido poligaracturônico e outros constituintes das paredes celulares. Envolvido na elongação celular e metabolismo do acido nucléico.

Silício Depositado como sílica amorfa nas paredes celulares. Contribui para propriedades mecânicas da parede celular, incluindo rigidez e elasticidade.

\section{Grupo 3 Nutrientes que permanecem na forma iônica}

Potássio Necessário como cofator para mais do que 40 enzimas. Principal cátion para estabilizar o turgor e manter a eletroneutralidade celular.

Sódio Envolvido com a regeneração da PEP nas plantas $\mathrm{C}_{4}$ e CAM. Substituído por potássio em algumas funções.

Magnésio Necessário para muitas enzimas envolvidas na transferência de fosfato. Constituinte da molécula de clorofila.

Cálcio Constituinte da lamela média das paredes celulares. Necessário como cofator por algumas enzimas na hidrolise do ATP e fosfolipídios. Atua como mensageiro secundário na regulação do metabolismo.

Manganês Necessário para atividade de algumas desidrogenases, descarboxilases, quinases, oxidases. Envolvidas com outras enzimas ativadas por cátion e evolução do $\mathrm{CO}_{2}$.

Cloro Necessário para reações fotossintéticas envolvidas na evolução do $\mathrm{CO}_{2}$.

\section{Grupo 4 Nutrientes que estão envolvidos na transferência de elétrons}

Ferro Constituinte dos citocromos e proteínas férricas envolvidas na fotossíntese, fixação de $\mathrm{N}_{2} \mathrm{e}$ respiração.

Cobre Componente do ácido ascórbico oxidase, citocromo oxidase, plastocianina, etc.

Zinco Constituinte da álcool desidrogenase, desidrogenase glutâmica, anidrase carbônica.

Molibdênio Constituinte da nitrogenase, nitrato redutase e xantina desidrogenase.

Níquel Constituinte da urease e hidrogenases. Importante nas bactérias fixadoras de $\mathrm{N}_{2}$.

Fonte: Evans e Sorget (1966). 
A adição ao solo ou solução nutritivade um elemento essencial em concentração inadequada pode resultar em desordem nutricional manifestada por sintomas típicos de deficiências ou toxidez. Em cultura hidropônica, a ausência do elemento essencial pode ser facilmente associado a um determinado sintoma. Porém, as diagnoses em plantas crescendo no solo podem ser mais complexas, pois vários elementos podem apresentar deficiências ou toxidez ao mesmo tempo, bem como concentrações excessivas de um determinado elemento podem induzir deficiências em outros e algumas doenças induzidas por vírus podem produzir sintomas similares a aquelas das deficiências nutricionais.

Os sintomas de deficiência ou toxidez nutricional na planta refletem a expressão de desordens metabólicas resultadas da adição insuficiente ou excessiva de um determinado elemento essencial. Estas desordens são relacionadas às atividades biológicas desempenhadas pelos elementos essenciais considerando a função do metabolismo normal da planta. De maneira geral, as funções dos elementos essenciais são: (1) como constituintes de compostos; (2) na ativação de enzimas; (3) na osmoregulação das células e (4) balanceamento iônico.

Os sintomas de deficiência e toxidez de um elemento essencial estão associados com a extensão de sua translocação das regiões mais velhas para as mais jovens. Alguns elementos como o nitrogênio, fósforo, magnésio e potássio podem facilmente translocar-se das folhas velhas para as mais jovens. Porém, outros como boro, ferro e cálcio são relativamente imóveis em diversas espécies vegetais. Se um elemento essencial é translocável, os sintomas da deficiência aparecerão primeiro nas folhas mais velhas. Diferente de um elemento essencial não translocável onde o sintoma se tornará evidente primeiro nas folhas mais jovens. Os hormônios vegetais como as citocininas parecem estar envolvidas no mecanismo de mobilização dos nutrientes (Taiz \& Zeiger, 1998). 
Com o passar dos anos muitas formulações têm sido utilizadas como solução de nutrientes. No início a formação desenvolvida por Wilhelm Knop na Alemanha incluía apenas alguns macronutrientes e um sal férrico. Acreditavase que essa solução nutritiva continha todos os nutrientes necessários para a planta. Mas outros elementos foram testados e são agora sabidos serem essenciais. A tabela 2 mostra de solução nutritiva, adaptada da solução nutritiva de Hoagland (1948) por Sarruge (1975). Esta solução contém todos os elementos minerais necessários para o crescimento vegetal. As concentrações desses elementos são estabelecidas nos maiores níveis possíveis, mas sem produzir sintomas de toxicidade ou estresse por salinidade, mas podem ser várias vezes maiores do que aquelas encontradas no solo ao redor das raízes das plantas (Marshner, 1995). Altos níveis iniciais permitem às plantas crescerem em um meio por longo período de tempo sem o reabastecimento dos nutrientes. Entretanto, muitos pesquisadores diluem suas soluções nutritivas e reabastecem-as freqüentemente a fim de minimizar flutuações na concentração do nutriente no meio de crescimento e no tecido da planta.

Outra importante propriedade da formulação de Hoagland é a possibilidade de o nitrogênio ser adicionado tanto na forma de amônio $\left(\mathrm{NH}_{4}{ }^{+}\right)$ como de nitrato $\left(\mathrm{NO}_{3}{ }^{-}\right)$. Acrescentando nitrogênio com mistura de cátions e ânions tende a reduzir o rápido aumento no $\mathrm{pH}$ do meio, o qual é observado quando adicionamos apenas o ânion nitrato. Quando o pH do meio é mantido neutro, diversas plantas respondem mostrando maior crescimento se beneficiando do acesso a ambas as formas de nitrogênio $\left(\mathrm{NH}_{4}{ }^{+}\right.$e $\left.\mathrm{NO}_{3}{ }^{-}\right)$, e do decorrente balanço cátion-ânion no interior da planta (Raven \& Smith, 1976; Bloom, 1994). 


\subsubsection{Cátions $\left(\mathrm{K}^{+}, \mathrm{Ca}^{+2} \mathrm{e} \mathrm{Mg}^{2+}\right)$ no metabolismo celular de plantas}

\subsubsection{Magnésio}

A exigência de $\mathrm{Mg}^{2+}$ para ótimo crescimento vegetal está na faixa de $0,15-0,35 \%$ do peso seco das partes vegetativas. A clorose de folhas totalmente expandidas é o sintoma mais visível da deficiência de $\mathrm{Mg}^{2+}$.

Magnésio é um cátion bivalente e sua absorção pode ser afetada por

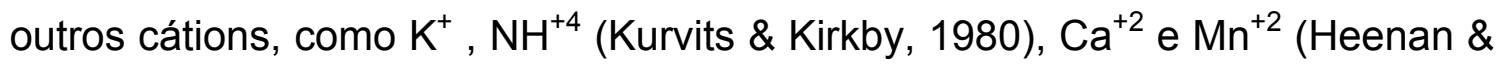
Campbell, 1981) assim como pelo $\mathrm{H}^{+}$, em condições de baixo $\mathrm{pH}$.

As funções do $\mathrm{Mg}^{2+}$ nas plantas resultam da sua capacidade de interagir fortemente com ligantes nucleofílicos (grupos fosforil) através de ligações iônicas. Embora as maiorias das ligações formadas envolvendo $\mathrm{Mg}^{2+}$ sejam iônicas, ligações covalentes como na molécula de clorofila também ocorrem. $\mathrm{O} \mathrm{Mg}^{2+}$ forma complexos ternários com enzimas, nos quais as pontes de cátions são necessárias para estabelecer uma geometria precisa entre enzima e substrato (Clarkson \& Hanson, 1980), como por exemplo a Rubisco (Ribulose 1,5-bisfosfato carboxilase/oxigenase) (Pierce, 1986). Uma proporção substancial do $\mathrm{Mg}^{2+}$ total está envolvida na regulação do $\mathrm{pH}$ celular e no equilíbrio cátion-ânion.

Nas partes verdes, a principal função do $\mathrm{Mg}^{2+}$ é seu papel como componente do átomo central da molécula de clorofila. A proporção do $\mathrm{Mg}^{2+}$ total ligado à clorofila depende da quantidade de $\mathrm{Mg}^{2+}$ total fornecido as plantas (Michael, 1941). Embora seja dependente da disponibilidade de $\mathrm{Mg}^{2+}$, entre 6\% e $25 \%$ do $\mathrm{Mg}^{2+}$ total está ligado à clorofila , outros $5-10 \%$ estão ligados a pectatos nas paredes celulares das folhas ou precipitado como sais solúveis no vacúolo (fosfato), e o restante $60-90 \%$ são eliminados com água pela transpiração.

Nas células de folhas adultas, $15 \%$ do volume celular é ocupado pelos cloroplastos, citoplasma e parede celular ( $5 \%$ cada), e o restante pelo vacúolo 
(Cowan et al.,1982; Leigh \& Wyn Jones, 1986). Similarmente ao fósforo inorgânico $(\mathrm{Pi})$, a concentração de $\mathrm{Mg}^{2+}$ que não está ligada fortemente nas estruturas orgânicas deve ser estritamente regulada. A concentração de $\mathrm{Mg}^{2+}$ no "pool metabólico" de células foliares, isto é, no citoplasma, cloroplastos e mitocôndria, é assumida estar na faixa de 2-10mM (Leigh \& Wyn Jones, 1986). Como para $\mathrm{Pi}$, o vacúolo é também o principal local de armazenamento do magnésio necessário para manter a homeostase no "pool metabólico". Da mesma forma, $\mathrm{O} \mathrm{Mg}^{2+}$ armazenado no vacúolo é também importante para o equilíbrio cátion-aniônico e regulação de turgor das células.

Em cloroplastos isolados, a fotossíntese pode ser inibida por concentração aproximada de $5 \mathrm{mM}$ de $\mathrm{Mg}^{2+}$ no citossol. Esta inibição é causada por um decréscimo no influxo de potássio e correspondente acidificação do estroma sob iluminação (Wu et al., 1991). Inibição da fotossíntese por altas concentrações de $\mathrm{Mg}^{2+}$ no "pool metabólico" pode ocorrer em plantas intactas sob estresse hídrico.

$\mathrm{O} \mathrm{Mg}^{2+}$ tem também função essencial na agregação das subunidades do ribossomo (Cammarano et al., 1972), processo necessário para a biossíntese da proteína. Quando o nível de $\mathrm{Mg}^{2+}$ livre é deficiente, ou na presença de níveis excessivos de $\mathrm{K}^{+}$(Sperrazza \& Spremulli, 1983), as subunidades dissociam-se cessando a síntese protéica. $O \mathrm{Mg}^{2+}$ é também necessário para a atividade das RNA polimerases e conseqüentemente para a formação de RNA nuclear. A síntese de RNA cessa imediatamente em resposta à deficiência de $\mathrm{Mg}^{2+}$, e a síntese recomeça imediatamente após sua adição. Nas células foliares das plantas verdes, no mínimo $25 \%$ da proteína total está localizada nos cloroplastos constituída principalmente da Rubisco. Isto explica porque a deficiência de $\mathrm{Mg}^{2+}$ afeta $\mathrm{o}$ tamanho, estrutura e função dos cloroplastos, incluindo a transferência de elétrons no fotossistema II (McSwrin et al., 1976). Nas plantas deficientes de $\mathrm{Mg}^{2+}$ ocorre a retranslocação das folhas maduras para as jovens e então sintomas típicos de deficiência de $\mathrm{Mg}^{2+}$ podem aparecer nas folhas maduras, indicando o aumento das taxas de degradação 
protéica, incluindo as proteínas estruturais dos tilacóides. Porém, em condições de deficiência ocorre acúmulo de amido nos cloroplastos, responsável pelo aumento no teor de matéria seca nas folhas de plantas deficientes de $\mathrm{Mg}^{2+}$ (Scott \& Robson, 1990).

Diversas enzimas e reações enzimáticas são fortemente ativadas pelo $\mathrm{Mg}^{2+}$. Por exemplo, a glutatione sintase e PEP carboxilase (Wedding \& Black, 1988). Muitas das reações dependentes de $\mathrm{Mg}^{2+}$ podem ser agrupadas pelo tipo de reação catalizada como transferência de fosfato (fosfatases \& ATPases) ou de grupos carboxílicos (carboxilases). O substrato para ATPases, assim como as PPi-ases inorgânicas (Rea \& Sanders, 1987), tem preferência para o complexo Mg-ATP do que ATP livre (Balke \& Hodges, 1975). A atividade máxima das ATPases requer a presença de $\mathrm{Mg}^{2+}$ e $\mathrm{K}^{+}$. Portanto, a concentração de $\mathrm{Mg}^{2+}$ livre afeta diretamente as reações de fosforilação (Yazaki et al., 1988).

A síntese de ATP (fosforilação: ADP $+\mathrm{Pi} \rightarrow$ ATP) exige também presença de $\mathrm{Mg}^{2+}$ como ponte entre ADP e a enzima. Em cloroplastos isolados a síntese de ATP (fotofosforilação) aumenta com a adição de $\mathrm{Mg}^{2+}$ promovendo ou estimulando a fotofosforilação. Cálcio em alta concentração inibe a fotofosforilação (Lin \& Nobel, 1975).

Outra reação relevante do $\mathrm{Mg}^{2+}$ é a modulação da Rubisco no estroma dos cloroplastos (Pierre, 1986). A atividade desta enzima é altamente dependente de $\mathrm{Mg}^{2+}$ e $\mathrm{pH}$. A ligação do $\mathrm{Mg}^{2+}$ com a enzima aumenta tanto sua afinidade $(\mathrm{Km})$ com $\mathrm{O}$ substrato $\mathrm{CO}_{2}$ como também a velocidade máxima (Vmáx) da reação (Sgiyama et al., 1968). $\mathrm{O} \mathrm{Mg}^{2+}$ pode afetar o $\mathrm{pH}$ fisiológico da reação. Nos cloroplastos durante a ativação da Rubisco pela luz observa-se o aumento tanto do $\mathrm{pH}$ como da concentração de $\mathrm{Mg}^{2+}$ no estroma. Sob iluminação, prótons são bombeados para o estroma dentro do espaço intratilacóide, criando um gradiente de próton necessário para a síntese de ATP. O transporte de prótons para o estroma induzido pela luz é equilibrado pelo transporte de $\mathrm{Mg}^{2+}$ do espaço intratilacóide dentro do estroma, o qual 
torna-se mais alcalino (Oja et al., 1986). Estas mudanças de $\mathrm{pH}$ e da concentração de $\mathrm{Mg}^{2+}$ são suficientes para aumentar a atividades da Rubisco e de outras enzimas do estroma.

Uma das enzimas importantes que requer $\mathrm{Mg}^{2+}$ e $\mathrm{pH}$ ótimo é a frutose1,6 -bisfosfatase, a qual nos cloroplastos, regula a partição de trioses entre a síntese de amido e a translocação para o citoplasma para síntese de sacarose (Gerhardt et al.,1987). Outra enzima fundamental no metabolismo que requer $\mathrm{Mg}^{2+}$ é a glutamina sintetase. A iluminação aumenta a atividade da nitrito redutase aumentando a produção de $\mathrm{NH}_{4}{ }^{+}$estimulando a atividade da glutamina sintetase responsável pela regulação e assimilação da amônia nos cloroplastos (O'negal \& Joy, 1974).

O acúmulo de carboidratos não estruturais (amido, açúcares) é tipicamente uma característica de planta deficiente de $\mathrm{Mg}^{2+}$ (Fischer \& Bussler, 1988) e condiciona maior quantidade de matéria seca nas folhas, sugerindo que a fotossíntese por si é pouco prejudicada.

Este acúmulo de carboidratos nas folhas, por exemplo em Phaseolus vulgaris, está relacionado com a diminuição no teor de carboidratos nas regiões de dreno como ocorre nas raízes de vagens (Fischer \& Bussler, 1988). A limitação de carboidrato fornecido para as raízes prejudica muito seu crescimento e aumenta o teor de matéria seca no broto (Scott \& Robson, 1990) O acúmulo de fotossintetizados nas folhas exerce uma regulação de "feedback" sobre a Rubisco em favor da reação oxigenase aumentando a fotorespiração. Conseqüentemente, as folhas deficientes de $\mathrm{Mg}^{2+}$ produzem mais radicais superóxidos $\left(\mathrm{O}_{2}^{-}\right)$e peróxidos de hidrogênio $\left(\mathrm{H}_{2} \mathrm{O}_{2}\right)$ aumentando a quantidade de antioxidantes como ascorbato e das enzimas removedoras de $\mathrm{H}_{2} \mathrm{O}_{2}$. Portanto, folhas deficientes de $\mathrm{Mg}^{2+}$ são muito fotossensitivas, e sintomas de clorose e necrose aumentam bastante com a intensidade de luz na qual as folhas estão expostas (Marschner \& Cakmak, 1989).

Aumentando o fornecimento de $\mathrm{Mg}^{2+}$ acima do nível de crescimento limite, resulta no seu armazenamento principalmente nos vacúolos, agindo 
como tampão para homeostase-Mg no "pool metabólico" e como critério para osmoregulação. Entretanto, altos teores de $\mathrm{Mg}^{2+}$ nas folhas $(1,5 \%$ da matéria seca foliar) poderiam tornar-se críticas sob estresse hídrico. Em girassol por exemplo, quando o potencial hídrico foliar diminui, a concentração de $\mathrm{Mg}^{2+}$ no estroma dos cloroplastos aumenta de aproximadamente $3-5 \mathrm{mM}$ para $13 \mathrm{mM}$ podendo inibir a fotofosforilação e a fotossíntese (Rao et al., 1987).

\subsubsection{Cálcio}

O teor de cálcio das plantas varia entre 0,1 e $5 \%$ do peso seco dependendo das condições de crescimento, das espécies e dos órgãos vegetais. A necessidade de cálcio para o ótimo crescimento é muito menor em monocotiledôneas do que em dicotiledôneas (Loneragan et al., 1968; Loneragan \& Snowball, 1969). Diferenças genotípicas quanto a exigência de cálcio estão exatamente associadas com os sítios de ligação nas paredes celulares, isto é, na capacidade de trocar cátion.

O cálcio é um cátion bivalente e, no apoplasto, parte está ligada estruturalmente, e a outra é translocável na parede celular e na superfície exterior da membrana plasmática. Grande parte do cálcio é armazenada no vacúolo, visto que sua concentração no citossol é extremamente baixa. Muitas das funções do cálcio como componente estrutural de macromoléculas são relacionadas à sua capacidade para coordenação, a qual proporciona estabilidade e conexão intermolecular reversíveis, predominantemente nas paredes celulares e na membrana plasmática. O cálcio pode ser fornecido em altas concentrações e pode atingir mais de $10 \%$ do peso seco, por exemplo em folhas adultas, sem ocorrer sintomas de toxicidade ou inibição do crescimento da planta. As funções do cálcio nas plantas foram compreensivelmente revisadas por, Kirkby \& Pilbeam (1984), Bush (1995), Sonders et al. (1999) e Reddy (2001). 
Ao contrário dos outros nutrientes, alto teor de cálcio está localizado freqüentemente nas paredes celulares dos tecidos ou apoplasma. Esta quantidade está associada a inúmeros sítios específicos nas paredes celulares e ao transporte de cálcio no citoplasma. Na lamela média o cálcio está ligado ao grupo carboxílico dos ácidos poligalacturônicos (pectinas) como forma de facilitar a troca iônica. Em dicotiledôneas, como a beterraba, a qual tem alta capacidade de trocar cátion, até $50 \%$ do cálcio total pode ser ligado como pectatos (Armstrong \& Kirkby, 1979). Por outro lado, em muitas angiospermas, cristais de oxalato de cálcio são armazenados nos vacúolos das células foliares (Borchert, 1990), no apoplasma, nas paredes celulares e nos espaços intercelulares (Fink, 1991a,c).

Existem compartimentos celulares distintos com altas ou muito baixas concentrações de cálcio. Altas concentrações são encontradas na lamela média da parede celular, na superfície exterior da membrana plasmática, no retículo endoplasmático e no vacúolo. A maior parte do cálcio solúvel é localizado nos vacúolos, acompanhado por ânions orgânicos como malato, ou ânions inorgânicos como nitrato e cloreto. Entretanto, no citossol, a concentração é extremamente baixa mantendo-se entre $0,1-0,2 \mu \mathrm{M}$ de $\mathrm{Ca}^{2+}$ livre (Felle, 1988; Evans et al., 1991). Essas concentrações baixíssimas são essenciais por várias razões: prevenir a precipitação de $\mathrm{Pi}$, evitar competição com $\mathrm{Mg}^{2+}$ por regiões de ligações específicas e é pré-requisito para funcionar como mensageiro secundário. As baixas concentrações de $\mathrm{Ca}^{2+}$ livre no citossol ocorrem geralmente devida baixa permeabilidade constitutiva das membranas para cálcio, e pela ação de transportadores da membrana removendo o cálcio do citossol e excretando-o para o apoplasma ou acumulando-o no retículo endoplasmático, nos cloroplastos, mitocôndria ou no vacúolo.

O principal transportador de cálcio na membrana plasmática e no RE é a bomba de cálcio ATPase $\left(\mathrm{Ca}^{2+} / \mathrm{H}^{+}\right.$antiporter) (Jones et al., 1993, Kasai \& Muto, 1990). De modo geral, estes "antipórteres" mantêm uma diferença de concentração superior a $10^{5}$ entre o $\mathrm{Ca}^{2+}$ livre no vacúolo e citossol (Schumaker 
\& Sze, 1990). Sob iluminação, o cálcio é transportado através de um gradiente de potencial eletroquímico do citossol para dentro do estroma nos cloroplastos.

Uma das enzimas importantes que requer baixas concentrações de $\mathrm{Ca}^{2+}$ livre no citossol é a frutose-1,6-bisfosfatase, a qual no cloroplasto regula a síntese de sacarose pelas trioses fosfatos. Concentração de $\mathrm{Ca}^{2+}$ muito baixa quanto $1 \mu \mathrm{M}$ ou muito alta quanto $1 \mathrm{mM}$ inibe sua atividade. Interessantemente, a frutose-1,6-bisfosfatase é mais estimulada do que inibida pelo aumento de $\mathrm{Ca}^{2+}$ livre no estroma (Kreimer et al., 1988). O efeito inibitório do $\mathrm{Ca}^{2+}$ sobre o $\mathrm{Mg}^{2+}$ é competitivo pelo sítio de ligação.

O cálcio ligado com o oligossacarídeo pectato na lamela média é essencial para o fortalecimento da parede primaria celular dos tecidos vegetais. Esta função do cálcio reflete-se da relação entre a capacidade de troca do cátion das paredes celulares e o teor de cálcio nos tecidos vegetais, necessários para um ótimo crescimento. A degradação de pectatos é mediada pela enzima poligalacturonase, a qual é inibida por altas concentrações de cálcio. De acordo com isto, a atividade da poligalacturonase aumenta em tecido deficiente de cálcio (Konno et al.,1984), podendo ocorrer a desintegração da parede celular e o colapso do tecido afetado como o pecíolo e parte superior do caule (Bussler, 1963).

Nas folhas de plantas recebendo altos níveis de cálcio durante o crescimento, ou sob condições de alta intensidade de luz, grande quantidade de material péctico existe como pectato de cálcio. Isto torna o tecido altamente resistente à degradação pela poligalacturonase (Cassels \& Barlass, 1976). O pectato de cálcio nas paredes celulares relaciona-se também com a defesa do tecido contra bactérias e fungos patogênicos e maturação dos frutos.

$\mathrm{Na}$ ausência de fornecimento de cálcio exógeno, a extensão da raiz cessa em pouco tempo (Maschner \& Richter, 1974). Embora o cálcio esteja envolvido na divisão celular (Schmit, 1981), a interrupção do crescimento da raiz devido a ausência de cálcio exógeno é primariamente o resultado da inibição da extensão celular. O cálcio proporciona rigidez à parede celular 
através de ligações com cadeias pécticas da lamela média. Por outro lado, para a parede celular crescer em extensão é necessário um enfraquecimento da mesma, um processo no qual ocorre acidificação induzida por auxina no apoplasma e ao mesmo tempo o cálcio é reposto para as ligações da cadeia péctica (Felle, 1988). A auxina também ativa canais de cálcio na membrana plasmática levando ao aumento temporário das concentrações de $\mathrm{Ca}^{2+}$ livre no citossol, o qual estimula a síntese de precursores da parede celular e sua secreção dentro do apoplasma (Brummell \& Hall, 1987).

O cálcio é necessário para a formação de vesículas secretórias e sua fusão com a membrana plasmática leva a exocitose ou de precursores para a formação da parede celular, assim como na formação de mucilagem ou calose (Steer, 1988b). Nas pontas de raízes, a secreção de mucilagem depende da concentração de cálcio extracelular. A remoção do cálcio extracelular reduz drasticamente a atividade secretória das células da ponta da raiz e também bloqueia a resposta gravitrópica das mesmas (Bennet et al., 1990).

A formação de calose é outro exemplo de processo secretório quando ocorre aumento de cálcio. Normalmente celulose (unidades de 1,4 $\beta$-glucano) é sintetizada na interface da membrana e a parede celular celulose. Em resposta a injúrias como lesão mecânica, infecção por parasita (Kauss, 1987;Kauss et al., 1991) ou altas concentrações de alumínio (Jorns et al., 1991) pode ocorrer o desvio de cálcio para produzir calose (unidades de 1,3 $\beta$-glucano)(Lerchl et al., 1989).

O estímulo da atividade de $\alpha$-amilase durante a geminação de sementes de cereais é um dos poucos exemplos de estimulação enzimática por altas concentrações de cálcio. $\mathrm{O}$ transporte de $\mathrm{Ca}^{2+}$ através das membranas do RE é estimulado por giberilinas (GA) e inibido por ácido abscísico ( $A B A$ ), levando a mudanças na atividade da a-amilase nas células de aleurona (Bush et al., 1993).

O papel fundamental do cálcio na estabilidade da membrana e integridade celular é refletida de várias maneiras. Isto pode ser demonstrada 
mais facilmente pelo aumento da perda de solutos de baixo peso molecular das células do tecido com deficiência de cálcio (Goor, 1966), deficiência pela desintegração das estruturas da membrana (Hecht-Buchholz, 1979) e perda da compartimentação celular.

O cálcio estabiliza as membranas celulares por pontes de fosfato e grupos carboxílicos de fosfolipídios (Caldwell \& Hang, 1981) e proteínas, preferencialmente nas superfícies das membranas (Legge et al., 1982). Podendo ocorrer substituição do cálcio por outros cátions $\left(\mathrm{K}^{+}, \mathrm{Na}^{+}\right.$ou $\left.\mathrm{H}^{+}\right)$ nessas regiões de ligação.

Para desempenhar suas funções na membrana plasmática, o cálcio deve estar presente na solução externa, onde regula a seletividade de absorção do íon e previne a perda de soluto do citoplasma. A ação do cálcio de proteger a membrana é maior sob condições de estresse como em baixas temperaturas (Zsoldos \& Karvaly, 1978) e anaerobiose.

Em tecidos deficientes de cálcio com a integridade da membrana prejudicada ocorre aumento da taxa de respiração, com a conseqüente saída de substratos respiratórios do vacúolo para as enzimas respiratórias no citoplasma. Portanto, a adição de cálcio nos tecidos com sintoma de deficiência não somente diminui a taxa de respiração como também aumenta a síntese de proteína (Bangerth et al., 1972). Estes fatores de deficiência de cálcio são similares àqueles relatados para senescência, onde em segmentos foliares a degradação de proteína e clorofila pode ser adiada pela adição de citocininas (benziladenina, BA) ou cálcio. A senescência é conseqüência da peroxidação dos lipídios das membranas pelos níveis elevados de radicais de oxigênio livre. O efeito protetor do cálcio e BA estão associados à baixa atividade da enzima lipoxigenase.

O cálcio não protege apenas as membranas lipídicas, mas também está envolvido no aumento da sua degradação. Isto é verdade para fosfolipídios e bem observada na degradação de membranas de corpos lipídicos em cotilédones durante a germinação de sementes de ricinus. Ao menos duas 
enzimas lipofílicas, as fosfolipases, associadas com corpos protéicos e lipídios são estimuladas pelo cálcio ou calmodulina (Paliyath \& Thompson, 1987).

O cálcio estimula uma série de enzimas ligadas à membrana plasmática, principalmente as ATPases nas raízes de algumas espécies vegetais (Kuiper \& Kuiper, 1979). Por causa da atividade das ATPases serem moduladas pela estrutura da membrana, o cálcio provavelmente aumente a atividade destas enzimas, embora o cálcio seja ligado em locais não catalíticos nas membranas. (Clarkson \& Hanson, 1980). Este estímulo requer concentrações milimolares de $\mathrm{Ca}^{2+}$ livre. Entretanto, para que enzimas citossólicas ou cloroplásticas sejam inibidas ou estimuladas, concentrações micromolares de cálcio são suficientes, sugerindo outro mecanismo de regulação.

A maior parte de cálcio armazenada no vacúolo, contribui para o equilíbrio cátion-ânion (Kinzel, 1989). Nas espécies vegetais que preferencialmente sintetizam oxalato em resposta à redução de nitrato a formação de oxalato de cálcio nos vacúolos é importante para manter baixa concentração de cálcio no citossol (Kinzel, 1989).

A formação de oxalato de cálcio solúvel é importante para a osmoregulação promovendo também o acúmulo de sais de nitrato nos vacúolos sem aumentar a pressão osmótica (Omond, 1967). Em folhas adultas de beterraba, por exemplo, acima de $90 \%$ do cálcio total é ligado ao oxalato (Egmond \& Bresteler, 1972).

Embora indiretamente, na sua função como mensageiro secundário, o cálcio tem papel relevante na osmoregulação. Os movimentos dos estômatos são processos típicos que regulam o turgor celular devido a mudanças de turgor nas células vizinhas e células guardas ou tecidos. Estas mudanças acontecem por fluxos principalmente de potássio, cloreto e malato como componentes osmóticos ativos. Porém, está estabelecida que para a transdução de sinais (luz, toque) gerando resposta fisiológica é necessário aumento transitório da concentração de $\mathrm{Ca}^{2+}$ citossólico (Roblin et al., 1989; Mansfield et al., 1990). A 
ação do ABA no fechamento do estômato depende das concentrações de cálcio na epiderme das folhas, quais são normalmente bem maiores do que as das outras células (Atkinson et al., 1990). A ativação induzida por ABA nos canais de cálcio e o rápido aumento nas concentrações de $\mathrm{Ca}^{2+}$ citossólico parecem bloquear as bombas de prótons e abrir canais para ânions, e ambos os eventos levam perdas de turgor nas células guardas e fechar os estômatos (Atkinson et al., 1990).

A função do cálcio como mensageiro secundário exige baixa concentração de $\mathrm{Ca}^{2+}$ no citossol entre $0,1-0,2 \mu \mathrm{M}$ (Trewavas \& Gilroy, 1991) e alta concentração nos compartimentos adjacentes. Sinais do ambiente podem ativar canais de cálcio nas membranas e conseqüentemente aumentar a entrada de $\mathrm{Ca}^{2+}$ no citossol. Esse aumento no citossol pode ser induzido por reguladores vegetais como ABA (Tester, 1990), AIA (Felle, 1988), luz (Roblin et al., 1989), infecção patogênica (Atkinson et al., 1990), ou por estresse mecânico ou injúria (Rincon \& Hanson, 1986). Sinais do ambiente como queda repentina da temperatura pode induzir a despolarização da membrana plasmática (Minorsky \& Spanswick, 1989), proporcionando a abertura dos canais (Davies, 1987). No citossol os principais alvos dos sinais de cálcio são as proteínas moduladas por cálcio, as calmodulinas (CAM) e as proteínas quinases dependentes de cálcio (Roberts \& Harmon, 1992). As proteínas quinases dependentes de cálcio são diretamente estimuladas por cálcio e fosforilam outras enzimas, como as ATPases localizadas na membrana (Roberts \& Harmon, 1992). Às vezes, o cálcio é ligado reversivelmente a uma calmodulina específica contendo quatro sítios ativos do polipeptídio, mudando sua conformação e atividade. Outra enzima dependente da CAM inclui a NAD quinase qual catalisa a conversão de $\mathrm{NAD}^{+}$para NADP, um aceptor terminal de elétrons nos cloroplastos. A CAM estimula também a translocação de cálcio ATPase, a qual é um importante componente na homeostase de cálcio no citossol. 
A concentração das CAMs são maiores nos tecidos meristemáticos e nas células da ponta da raiz do que em muitas regiões maduras das plantas (Roberts \& Harmon, 1992).

\subsubsection{Potássio}

O potássio é cátion univalente, tem absorção altamente seletiva, alta mobilidade intracelular e tecido, e no transporte à longa distância via xilema e floema. O potássio é abundante no citoplasma e quando associado a ânions contribui com o potencial osmótico celular dos vegetais. Por várias razões possui papel fundamental na relação água-planta (Hsiao \& Läuchli, 1986). O potássio não é metabolizado e forma apenas complexo fraco, o qual é facilmente dissociável (Wyn Jones et al., 1979). Portanto, $\mathrm{K}^{+}$não compete fortemente por locais de ligação com cátions bivalentes, como $\mathrm{Mg}^{2+} \mathrm{e} \mathrm{Ca}^{2+}$. Por outro lado, devido a sua alta concentração no citossol e cloroplastos, o potássio neutraliza ânions solúveis de ácidos orgânicos e inorgânicos, ânions insolúveis e estabiliza $\circ \mathrm{pH}$ entre 7-8 nesses compartimentos, considerado ótimo para muitas reações enzimáticas. Por exemplo, a diminuição no pH de 7,7 para 6,5 praticamente inibe a atividade da nitrato redutase (Pflüger \& Wiedemann, 1977). As várias funções do potássio nas plantas foram revisadas por Läuchli \& Pflüger (1978).

Geralmente, as concentrações de potássio no citossol e nos cloroplastos variam entre 100-200mM (Leigh \& Wyn-Jones, 1984; SchroppelMeier \& Kaiser, 1988). Com relação as suas funções, nesses compartimentos, o $\mathrm{K}^{+}$pode ser substituído por outros cátions inorgânicos tal como $\circ \mathrm{Na}^{+}$. Em outros compartimentos as concentrações de $\mathrm{K}^{+}$podem variar, como nos vacúolos (Hsiao \& Läuchli, 1986), ou podem atingir concentrações maiores nas células guardas do estômato (Outlaw, 1983). As funções do $\mathrm{K}^{+}$nos processos de extensão celular e turgor estão relacionados com a concentração de $\mathrm{K}^{+}$nos 
vacúolos, podendo ser substituído, dependendo de sua variação, por outros cátions como $\mathrm{Na}^{+}, \mathrm{Mg}^{2+}, \mathrm{Ca}^{2+}$ ou solutos orgânicos como açúcares.

Para ocorrer transporte de $\mathrm{K}^{+}$entre os diferentes compartimentos celulares e intracelulares nos cloroplastos, quando iluminados, canais de $\mathrm{K}^{+}$são abertos nas membranas dos tilacóides transportando-o para o espaço intratilacóide e estroma (Tester \& Blatt, 1989). Os canais das membranas abrem-se e fecham-se em seqüências e tamanhos diferentes em resposta aos sinais externos do ambiente e mudanças no potencial elétrico das membranas. (Tester, 1990). Embora os canais de $\mathrm{K}^{+}$sejam em princípio similares aos canais de $\mathrm{Ca}^{2+}$, sua função é totalmente diferente. O potássio age diretamente como soluto mudando o potencial osmótico nos compartimentos, provocando turgescência celular, e como transportadores de cargas no potencial da membrana.

Várias enzimas são dependentes ou estimulados por K (Suelter, 1970). O potássio e outros cátions univalentes ativam enzimas por mudanças conformacionais na proteína-enzima. Todas as macromoléculas são hidrofílicas e estabilizadas por moléculas de água formando uma dupla camada elétrica. Geralmente, mudanças conformacionais nas enzimas induzidas por $\mathrm{K}^{+}$ aumentam a velocidade das reações catalíticas, Vmáx, e em alguns casos também a afinidade com o substrato, Km (Evans \& Wildes, 1971).

Nas plantas deficientes de $\mathrm{K}^{+}$ocorrem mudanças químicas, incluindo acúmulo de carboidratos solúveis, diminuição no teor de amido e acúmulo de compostos nitrogenados solúveis. Essas mudanças no metabolismo de carboidrato estão relacionadas possivelmente com alta necessidade de $\mathrm{K}^{+}$por determinadas enzimas regulatórias, como a piruvato quinase e a fosfofrutoquinase (Läuchli \& Pflüger, 1978). A atividade da amido sintase, a qual cataliza a transferência da glicose para moléculas de amido, tem alta dependência de cátions univalentes, sendo $\circ \mathrm{K}^{+} \circ$ mais efetivo. $\mathrm{O}$ potássio similarmente ativa a amido sintase isolada de diversas espécies vegetais e órgãos como folhas, sementes e tubérculos numa concentração entre 50- 
100mM (Nitkos \& Evans, 1969). Porém, concentrações maiores podem ter efeitos inibitórios (Preusser et al., 1981).

Outra função do $\mathrm{K}^{+}$é a ativação das bombas de prótons $\mathrm{H}^{+} / \mathrm{ATPases}$ ligadas à membrana facilitando tanto seu transporte da solução externa através da membrana plasmática para dentro das células da raiz, como também é o elemento mineral essencial na extensão celular e osmoregulação.

O potássio é necessário para síntese protéica em maiores concentrações do que para a ativação enzimática. Em sistemas livres de células a taxa de síntese de proteína pelos ribossomos de germe de trigo exige a presença de altas concentrações de potássio e baixas de magnésio. É provável que esteja envolvido em várias etapas no processo de tradução, incluindo a formação do RNA transportador (tRNA) para os ribossomos (Wyn Jones et al., 1979). Em folhas verdes os cloroplastos são responsáveis pela síntese de aproximadamente metade do RNA e proteínas foliares. Nas plantas C3, a maior parte das proteínas do cloroplasto é a Rubisco. Conseqüentemente a síntese desta enzima é prejudicada sob deficiência de potássio e responde ativamente com sua adição.

Nas plantas que apresentam deficiência de potássio ocorre acúmulo de compostos nitrogenados solúveis como aminoácidos, amidos e nitrato (Mengel \& Helal, 1968), demonstrado pela incorporação de nitrogênio inorgânico marcado $\left({ }^{15} \mathrm{~N}\right)$ dentro da fração protéica (Koch \& Mengel, 1974). Estudos feitos por Pflüger \& Wiedemann (1977) sugerem que $\mathrm{K}^{+}$não somente ativa a nitrato redutase, mas também é necessária para sua síntese. Por outro lado, sob deficiência de $\mathrm{K}^{+}$a expressão de alguns polipeptídios ligados à membrana aumenta (Fernando et al., 1990).

Nas plantas superiores o potássio afeta a fotossíntese em vários níveis como íon responsável pelo fluxo de $\mathrm{H}^{+}$originado pela fotólise da água induzido pela luz através das membranas do tilacóide (Tester \& Blatt, 1989), para o estabelecimento do gradiente de $\mathrm{pH}$ da transmembrana, necessário para a síntese de ATP, fotofosforilação, em analogia à síntese de ATP na mitocôndria. 
A importância do $\mathrm{K}^{+}$na fixação de $\mathrm{CO}_{2}$ pode ser demonstrado claramente em cloroplastos isolados (Pflüger \& Cassier, 1977). Para manter o $\mathrm{pH}$ alto no estroma sob iluminação, ocorre a entrada adicional de $\mathrm{K}^{+}$do citossol mediado por um fluxo contrário de $\mathrm{H}^{+}$através do envelope dos cloroplastos (Wu et al., 1991). Este fluxo é prejudicado sob estresse hídrico. Durante a desidratação de cloroplastos isolados perde-se grande quantidade de $\mathrm{K}^{+} \mathrm{e}$ diminui a fotossíntese. Entretanto, este decréscimo pode ser superado por altas concentrações de $\mathrm{K}^{+}$extracloroplastidiais (Píer \& Berkowitz, 1987). A importância de repor $\mathrm{K}^{+}$nas folhas de plantas expostas a estresse hídrico ou salinidade (Chow et al., 1990) está ligado a necessidade de manter altas concentrações de $\mathrm{K}^{+}$no estroma (Sen Gupta et al., 1989).

Plantas deficientes de $\mathrm{K}^{+}$afeta a absorção de $\mathrm{CO}_{2}$. Aumentando o teor de potássio nas folhas aumenta a taxa de fotossíntese e atividade da RuBP carboxilase, assim como a fotorespiração, provavelmente devido a uma forte diminuição de $\mathrm{CO}_{2}$ nas regiões catalíticas da enzima. Com o aumento no teor de $\mathrm{K}^{+}$, a respiração no escuro diminui. Maiores taxas de respiração são sintomas típicos de deficiência de $\mathrm{K}^{+}$(Botrill et al., 1970). Obviamente, o estado nutricional pode também afetar a fotossíntese nas folhas devido sua função na regulação dos estômatos (Peoples \& Koch, 1979).

Alto potencial osmótico nos vasos das raízes é essencial para o transporte de solutos no xilema e manter o equilíbrio hídrico nas plantas. Em princípio, em relação às células individuais ou em certos tecidos, os mesmos mecanismos são responsáveis pela extensão celular e vários tipos de movimento. O potássio como principal soluto inorgânico, é indispensável nesses processos (Hsiao \& Läuchli, 1966).

Extensão celular envolve a formação de um grande vacúolo central ocupando $80-90 \%$ do volume celular. São dois os principais requisitos para ocorrer a extensão celular: aumento na extensão da parede e o acúmulo de soluto para criar um potencial osmótico interno. Em muitos casos, a extensão celular é conseqüência do acúmulo de $\mathrm{K}^{+}$nas células, o qual está associado a 
estabilização do pH no citoplasma e ao aumento do potencial osmótico nos vacúolos. Em folhas expandidas de feijão com deficiência de $\mathrm{K}^{+}$, o turgor, o tamanho da célula e as áreas foliares foram significativamente menores do que nas folhas suplementadas com $\mathrm{K}^{+}$(Mengel \& Arneke, 1982). Esta relação inversa entre o estado nutricional de $\mathrm{K}^{+}$e tamanho celular também ocorrem nos tecidos de reserva de cenouras (Pfeiffenschneider \& Beringer, 1989).

A elongação do caule por GA é também dependente da adição de $\mathrm{K}^{+}$. Potássio e GA agem sinergicamente e maior elongação é obtida quando ambos são aplicados. Alguns resultados parecem indicar que $\mathrm{K}^{+}$e açúcares redutores agem de uma maneira complementar para produzir o potencial de turgor necessário para extensão celular.

Alguns trabalhos demonstram que $\mathrm{K}^{+}$em associação com ânions de ácidos orgânicos e inorgânicos é o principal soluto necessário nos vacúolos para extensão celular (Guardiã \& Benloch, 1980). A dimensão, pelos quais açúcares e outros solutos orgânicos de baixo peso molecular contribue para o potencial osmótico e turgor com expansão celular, dependem do estado nutricional de $\mathrm{K}^{+}$nas plantas (Schnyder et al., 1988).

Após completar a extensão celular, para manter o turgor celular o $\mathrm{K}^{+}$ pode ser substituído nos vacúolos por outros solutos como o $\mathrm{Na}^{+}$ou açúcares redutores. Relações inversas entre as concentrações de $\mathrm{K}^{+}$no tecido e açúcares redutores em particular, são fenômenos comuns (Pitman et al., 1971) e podem também ser observados durante o crescimento dos tecidos de armazenagem. Segundo Steingrover (1983) o potencial osmótico da seiva de raízes de cenouras permanece constante em qualquer momento do crescimento. Antes de iniciar a armazenagem de açúcares, $\mathrm{K}^{+} \mathrm{e}$ ácidos orgânicos predominam como substâncias osmóticas. Entretanto, durante a armazenagem, um aumento na concentração de açúcares redutores é compensado por um decréscimo correspondente na concentração de $\mathrm{K}^{+} \mathrm{e}$ ânions de ácidos orgânicos (Beringer et al., 1986). 
Em muitas espécies vegetais $0 \mathrm{~K}^{+}$associado com um ânion tem como principal função mudar o turgor nas células guardas durante o movimento estomatal. Aumento na concentração de $\mathrm{K}^{+}$nas células guardas aumenta seu potencial osmótico e resulta na absorção de água das células adjacentes e conseqüentemente a abertura do estômato. $O$ fechamento do estômato induzido por $A B A$ à noite ocorre com a saída de $\mathrm{K}^{+} \mathrm{e}$ ânions das células guardas alterando a pressão osmótica e pH do apoplasma destas células (Edwards et al., 1988). O ABA pode derivar das raízes via xilema como um sinal "não-hidráulico" (Davies \& Meinzer, 1990), talvez estimulado por baixa concentração simultânea de citocinina (Meinzer et al., 1991).

Os açúcares têm sido discutidos como solutos osmóticos alternativos para a abertura estomatal (Tallman \& Zeiger, 1988). Entretanto, a taxa de produção de açúcar nas células guardas é insuficiente para atingir a alta concentração necessária para ocorrer rápida abertura estomatal (Reckmann et al., 1990). Porém, em condições de deficiência de $\mathrm{K}^{+}$, carboidratos podem contribuir substancialmente para a osmoregulação nas células guardas (Poffenroth et al., 1992). Esta resposta lenta do acúmulo de açúcar nas células guardas resulta na incompleta abertura e fechamento dos estômatos em plantas deficientes de potássio (Hsiao \& Läuchli, 1986).

O potássio tem funções importantes no carregamento de sacarose e no transporte de soluto dirigido pelo fluxo de massa nos tubos crivados. Esta função do $\mathrm{K}^{+}$é necessária para manter o potencial osmótico e pH alto nos tubos crivados possibilitando o transporte de fotossintetizados da fonte para o dreno. Nas plantas com níveis normais de potássio aproximadamente metade dos fotossintetizados marcados com $\mathrm{C}^{14}$ são exportados das folhas para outros órgãos, e $20 \%$ para o caule como ocorre em cana de açúcar. Porém em plantas deficientes as taxas exportadas são bem menores.

Similarmente, em legumes suplementados com $\mathrm{K}^{+}$, os nódulos da raiz têm maiores taxas de açúcar, a qual aumenta a fixação e exportação de $\mathrm{N}_{2}$ (Mengel et al., Collins \& Duke, 1981). 
$\mathrm{Na}$ compensação de carga, o $\mathrm{K}^{+}$é $\mathrm{o}$ cátion dominante para contrabalancear ânions imóveis no citoplasma, nos cloroplastos, e quase freqüentemente para ânions móveis nos vacúolos, xilema e floema. O acúmulo de ânions de ácidos orgânicos nos tecidos vegetais ocorre normalmente devido ao transporte de $\mathrm{K}^{+}$no citoplasma (raiz ou células guardas). $\mathrm{O}$ papel do $\mathrm{K}^{+}$no equilíbrio cátion-ânion é também refletido no metabolismo do nitrato, o qual $\mathrm{K}^{+}$é o íon contrabalanceador dominante para $\mathrm{NO}_{3}^{-}$no transporte à longa distância no xilema assim como para estoque nos vacúolos. Como conseqüência da redução de $\mathrm{NO}_{3}^{-}$nas folhas, o $\mathrm{K}^{+}$remanescente requer síntese estequiométrica dos ácidos orgânicos para o balanço das cargas e homeostase do pH. Parte do malato de potássio recém formado pode ser retranslocado para as raízes para subseqüente utilização de $\mathrm{K}^{+}$como íon contrabalanceador do $\mathrm{NO}_{3}^{-}$para o transporte no xilema. Em legumes, esta retranslocação de $\mathrm{K}^{+}$pode servir como função similar no transporte de aminoácidos no xilema (Jeschke et al., 1985).

\subsection{Cultura de tecidos de plantas}

O uso da cultura de tecidos de plantas no estudo do metabolismo celular vegetal tem alguns aspectos únicos e vantagens sobre o uso de plantas intactas. Estas vantagens incluem: (1) rápido crescimento exponencial com população podendo dobrar num período de 1-4 dias; (2) populações consistindo de um número limite de fenótipos celulares sem a divisão dos sistemas de transporte das plantas intactas; (3) livre de contaminantes por microorganismos e (4) uma maior amplitude de manipulações ambiental e nutricional com cultura de células do que possíveis com plantas intactas.

As técnicas de cultura de tecido in vitro vêm expandindo as fronteiras na pesquisa básica com vegetais superiores, possibilitando sua aplicabilidade em diversas áreas, tais como o melhoramento genético de plantas, farmacologia, obtenção de culturas livres de doenças, micropropagação e 
preservação de germoplasma. A conservação de coleções ativas de germoplasma in vitro constitui alternativa de reconhecidos méritos e vantagens sobre as coleções conservadas in vivo, principalmente para culturas que requerem renovações anuais ou bianuais da coleção como é o caso da cenoura (Daucus carota), do alho (Allium sativum), da batata (Solanum tuberosum), da mandioca (Manihot esculenta) e da batata-doce (Ipomoea batatas) (Roca et al., 1982).

Baseado no fenômeno da totipotência das células vegetais, isto é, na capacidade de uma única célula se diferenciar formando uma planta completa, a cultura de tecidos possibilita a regeneração de uma planta idêntica à planta mãe contendo todas as informações genéticas num processo caracterizado como clonagem a partir de fragmentos de seus órgãos.

O controle da morfogênese utilizando tecidos cultivados in vitro é feito através da introdução exógena de estímulos químicos e de substratos diversos. A retirada de segmentos de tecidos de um organismo íntegro e sua transferência para meio de cultura conténdo nutrientes e reguladores de crescimento apropriados, traz como conseqüência a liberação de suas células do controle a que estavam submetidas nesse organismo e expondo-as a uma condição alterada, permite que o potencial de divisão celular possa expressarse de novas formas, podendo levar à formação de novas estruturas organizadas, num processo morfogenético que ocorre de novo (Handro \& Floh, 1990).

Atualmente são considerados 5 tipos principais de cultura de tecidos vegetais: (1) cultura de calos; (2) suspensões celulares; (3) cultura de órgãos e células gaméticas (embriões, óvulos e anteras); (4) cultura de meristemas e (5) cultura de protoplastos (Crocomo \& Ochoa-Alejo, 1983).

Uma das respostas mais comuns induzida em um tecido cultivado in 
vitro é a formação de calo, que é caracterizado por uma massa de células não diferenciada, de proliferação contínua e desordenada. A partir das células de um calo pode ocorrer a formação de gemas que evoluem para formarem eixos caulinares. Quando a organogênese ocorre diretamente a partir das células do explante original, fala-se em organogênese direta; por outro lado, quando ocorre a partir de células de calo formado no explante, fala-se em organogênese indireta. Um outro processo de morfogênese é a embriogênese, onde a partir de células somáticas dos tecidos do explante ou de calos, organizam-se estruturas bipolares semelhantes aos embriões zigóticos, sendo por esta razão denominado embriogênese somática. A embriogênese também pode ser um processo direto ou indireto (Handro \& Floh, 1990).

A propagação clonal de plantas através das técnicas de cultura de tecidos, tem sido praticada em inúmeras herbáceas (Bhojwani, 1990), principalmente na produção de matrizes e propagação assexuada de plantas economicamente importantes (Bhojwani, 1990; Debergh, 1990 Jones, 1987).

Portanto, a cultura de células tem sido utilizada tanto para estudar os aspectos do metabolismo universal, como a biossíntese de aminoácidos e síntese de ácidos nucléicos, como também os aspectos do metabolismo que são unicamente observadas nas plantas, como a fotossíntese e biossintese da parede celular.

\subsubsection{Fatores que afetam a morfogênese in vitro}

George \& Sherrinton (1984) ressaltam que vários fatores podem atuar no processo de crescimento e morfogênese de uma cultura in vitro. Esses fatores podem ser divididos em quatro grupos: (1) genótipo do material a ser cultivado; (2) substrato, representado pelos componentes do meio de cultura e 
inclusive a presença de fitorreguladores; (3) ambiente, que se refere às condições físicas do ambiente de crescimento; e (4) fatores do explante.

Segundo os mesmos autores, os fatores do explante podem incluir: a natureza física (idade e tipo) e as condições em que a planta mãe tem sido cultivada. Murashige (1974) destaca que muitos fatores influenciam o comportamento do explante em cultura. Estes incluem (1) o órgão que funciona como fonte de explante, (2) a idade fisiológica e ontogenética do órgão, (3) a época em que os explantes foram obtidos, (4) tamanhos do explante, e (5) as características da planta em que os explantes foram obtidos.

\subsubsection{Genótipo}

Grattapaglia \& Machado (1990) afirmam que pode ocorrer variabilidade na resposta morfogenética in vitro não somente entre espécies do mesmo gênero, mas também entre genótipos da mesma espécie (diferentes cultivares ou clones).

Dado a variabilidade genética dentro de sementes obtidas por polinização aberta de variedades de cenoura, culturas de células oferecem um método atrativo para a produção de plantas geneticamente idênticas em grande número para interesse comercial.

$\mathrm{Na}$ literatura existem vários estudos mostrando que a embriogênese somática é altamente dependente do genótipo (Hanninger \& Conger, 1986; Parrot et al., 1989; Trigiano et al., 1989) e destacam ainda que o genótipo é o fator determinante nos processos de resposta in vitro. Relata que a capacidade de regeneração para milho e trigo está sob controle genético, onde cromossomos específicos estariam envolvidos nesse processo. Provavelmente os genes que controlam a síntese de hormônios vegetais estariam localizados nestes cromossomos. 


\subsubsection{Meio de cultura}

O desenvolvimento de protocolos para indução de calos e regeneração de plantas é essencial para aplicação, com êxito, de técnicas moleculares no cultivo e melhoramento de plantas. Regeneração de plantas por meio de embriogênese somática bem como organogênese tem sido descrita em grande número de plantas cultivadas (Eapen \& George, 1989; Sivadas et. al, 1990; Sivadas et. al, 1992).

Em cultura de tecidos de cereais e outras plantas, o meio de MS (Murashige \& Skoog, 1962) é o mais freqüentemente utilizado.

Murashige \& Skoog (1962) recomendaram a importância da interação entre os sais nutrientes e reguladores de crescimento, e suas necessidades variadas em diferentes tecidos e plantas.

Poddar et. al (1997) investigou diferentes níveis de nitrato de amônia para regeneração de calos embriogênicos de Eleusine coracana na presença e ausência de NAA (1-ácido naftalenoacético). Oziaz-Akins \& Vasil (1993) observou que embrióides típicos em trigo formaram calos brancos e que a formação deles foi aumentado pelo dobro da concentração dos macroelementos no meio de cultura.

Estudos feitos por De Fossard et. al. (1976) sugeriram a interação entre diferentes nutrientes e reguladores de crescimento que ocorre durante $\mathrm{o}$ processo de crescimento in vitro e diferenciação em células de calos de tabaco. O meio nutritivo também afetou a resposta do explante ao regulador vegetal na organogênese. Absorção de nitrogênio também tem influência no crescimento e regeneração de plantas (Lillo, 1989).

Segundo Xu \& Bewley (1992) auxinas, em particular 2,4diclorofenoxacético (2,4D), é extremamente importante na indução de calogênese e células embriogênicas e na posterior remoção da auxina do meio de cultura, estas células formam embriões somáticos. 
Estudos feitos por May \& Trigiano (1991), mostram que a concentração de sacarose no meio de cultura regula as alterações no desenvolvimento do explante de Dendranthema grandiflora, onde em baixas concentrações (3\% a $6 \%$ ) ocorre a organogênese, e em altas concentrações (12\% a 18\%) a embriogênese é favorecida. Também em Helianthus annus, a concentração de sacarose é fator chave para ocorrer a organogênese ao invés de embriogênese. Num meio com baixa concentração de sacarose, organogênese foi induzida ao invés de embriogênese, que pode ser obtida em meio contendo alto nível de sacarose (Bronner et al., 1994).

\subsubsection{Condições ambientais}

A morfogênese é fundamentalmente $o$ resultado de divisão e diferenciação celular organizadas, com padrões definidos, e que dependem, basicamente, da atividade e expressão de certos genes. Assim fatores que controlam ou afetam esses eventos são os responsáveis pela morfogênese. Tais fatores são variados e interagem de diversas formas, sendo quase que impossível caracterizar um único fator específico para cada fenômeno morfogênico. Os efeitos isolados ou sinergísticos desses fatores variam de acordo com as condições de cada tipo de célula, que podem ser mais ou menos definidos de acordo com o tecido, órgão, espécie, variedade ou cultivar, e peculiar para uma dada condição fisiológica de momento (Handro \& Floh, 1990).

Em cultura de tecidos, os principais fatores que controlam a morfogênese são os fitorreguladores, principalmente $\circ$ balanço [auxina]/[citocinina] no meio de cultura, fato estabelecido no clássico trabalho de Skoog \& Miller (1957). Esses autores verificaram que tal balanço, se convenientemente manipulado, induzia em calos originados da medula de fumo, raízes, gemas caulinares ou apenas mais tecido de calo. Numa primeira tentativa, pode-se usar citocininas do tipo benziladenina (BA) ou cinetina (CIN), 
e como auxina, o ácido indolilacético (AIA) ou 2,4-diclorofenoxiacético (2,4-D). No caso das auxinas, os tecidos podem apresentar respostas diversas de acordo com o tipo empregado. O 2,4-D, por exemplo, induz calos mais facilmente e é conhecido como determinante de embriogênese somática (Ammirato, 1983). O ácido abscísico (ABA) tem, em geral, efeitos inibitórios, sendo raramente utilizado no controle da morfogênese, apesar de se encontrar na literatura casos de estimulação.

Deve-se enfatizar, entretanto, que $\circ$ balanço entre as [auxinas]/[citocininas] não é o único responsável pelo controle da organogênese. Inúmeros outros fatores, tais como: nível e formas de fonte de nitrogênio $\left(\mathrm{NO}_{3}{ }^{-}, \mathrm{NH}_{4}{ }^{+}\right.$e aminoácidos); nível e tipo de fonte de carbono (sacarose, glicose), constituinte de ácidos nucléicos (adenina, guanina, ácido orótico), compostos fenólicos (cofatores ou inibidores de AIA-oxidase) e vitaminas, têm efeitos morfogênicos quando adicionados ao meio de cultura (Kerbauy et al., 1988). Deve-se lembrar, ainda, que muitos tecidos cultivados in vitro são capazes de sintetizar citocininas e auxinas (autonomia), capacidade esta já presente, ou adquirida em cultura (Kerbauy et al., 1986; Kerbauy et al., 1988).

Os fatores físicos que podem exercer efeito sobre as culturas e interferir nos processos morfogênicos são: o estado físico do meio, o pH, a temperatura e a luz. A luz é o fator que maiores efeitos exerce nos processos morfogênicos que ocorrem in vitro. Sua intensidade, qualidade e duração afetam particularmente o processo fotossintético e os processos mediados pelo fitocromo. Para muitas espécies, a organogênese em tecidos de calo só ocorre na luz, a partir das regiões mais verdes, como em Stevia rebaudiana (Ferreira \& Handro, 1988). Entretanto, a partir de explantes foliares, a neoformação de gemas pode ocorrer no escuro (Ferreira \& Handro, 1987). Em espécies fotoperiódicas para a floração, tecidos cultivados in vitro podem mostrar respostas morfogênicos muito características, dependendo do regime fotoperiódico a que as culturas são submetidas. Em Streptocarpus nobilis, por 
exemplo, discos foliares cultivados em dias curtos produzem gemas florais, e em dias longos, gemas vegetativas (Handro, 1983).

Audran et al. (1994) ao trabalharem com híbridos de Cichorium comprovaram que a morfogênese é dependente da temperatura e esta promove o desenvolvimento de calos e brotos a $20^{\circ} \mathrm{C}$ e $25^{\circ} \mathrm{C}$, enquanto que a $35^{\circ} \mathrm{C}$ a embriogênese somática é promovida. A $30^{\circ} \mathrm{C}$ pode-se observar tanto organogênese quanto embriogênese, porém esta temperatura intermediária claramente mostrou a mudança de embriogênese para organogênese.

\subsubsection{Tipo de explante}

Uma planta íntegra é um sistema pluricelular altamente diversificado, originado de uma célula inicial única, o zigoto, com seu complemento genético característico (totipotência). A partir das primeiras divisões, a diferenciação celular se estabelece em diferentes graus, que culmina na planta adulta, num sistema de órgãos e tecidos especializados, onde apenas algumas células retêm a capacidade de divisão. A morfogênese é conseqüência dos processos de divisão e diferenciação celular integrados, conduzindo à um nível de organização supra celular. Tais processos dependem de certos sinais (fitohormônios e luz, principalmente) que agindo direta ou indiretamente ao nível gênico, desencadeiam processos específicos de síntese, e como conseqüência, alterações metabólicas e bioquímicas diversas.

Nos tecidos em cultura, o controle da organogênese é feito através da introdução exógena de sinais e de substratos diversos. A retirada de um fragmento de tecidos de um organismo íntegro e sua colocação no meio de cultura que contém nutrientes e reguladores de crescimento traz como conseqüência a liberação de suas células do controle a que estavam submetidas nesse organismo, expondo-as a uma nova condição, onde a capacidade de divisão pode ser readquirida (desdiferenciação) e o genoma

pode expressar-se de novas formas conduzindo-as a novos padrões de 
diferenciação. Esses eventos podem, de diversas maneiras, levar a formação de novas estruturas organizadas, num processo morfogenético ou organogenético que ocorre de novo.

Antes de qualquer análise das respostas dos tecidos cultivados in vitro, deve-se considerar algumas peculiaridades relativas à sua natureza: os explantes podem apresentar diferentes tipos de células e graus de diferenciação (por exemplo, fragmentos de folha, segmentos de caule), ou serem histologicamente mais homogêneos (meristemas e medula caulinar). Deve-se lembrar ainda, que mesmo em explantes mais homogêneos quanto a sua constituição histológica, tal homogeneidade pode ser aparente: a medula caulinar do fumo, mostra ao longo do caule, um gradiente de ploidia que se reflete nas respostas quando da cultura in vitro (Murashige \& Nakano, 1967; Kraus et al., 1981; Floh \& Handro, 1985a, b). Por outro lado, explantes da mesma natureza, retiradas de plantas em diferentes condições fisiológicas, podem apresentar respostas bastante distintas, como, por exemplo, em Stevia rebaudiana e Petunia inflata (Ferreira \& Handro, 1988; Handro et al, 1973).

\subsubsection{Padrões morfogênicos de diferenciação celular que ocorrem in vitro}

Uma das respostas mais comuns de um tecido cultivado in vitro é a formação de calo, ou seja, de uma massa de células de proliferação contínua e mais ou menos desordenada. Sua formação pode ser dividida basicamente em três estágios: indução, divisão e diferenciação. Tais estágios são caracterizados por alterações no tamanho celular, estruturas e condições metabólicas do tecido (Aitchison et al., 1977).

Em certos casos a cultura in vitro não promove a formação de calos, mas apenas uma proliferação celular restrita às regiões seccionadas do explante com formação de tecidos de cicatrização e zonas de intensa atividade meristemática. A partir das zonas de atividade meristemática em tecidos de calo e também, nos explantes primários, as divisões celulares e o padrão de 
diferenciação podem ocorrer de maneira que conduza a um grau de organização morfo-anatômica peculiar, que no caso de caracterizar um órgão definido, constitui-se no processo denominado organogênese. Uma outra possibilidade é a utilização direta de tecidos meristemáticos, especialmente ápices caulinares e radiculares (Kerbauy, 1984a,b; Kunieda \& Kerbauy, 1986), onde ocorre grande homogeneidade e as células estão sempre num processo ativo de divisão, o que facilita a indução dos processos organogênicos.

Em explantes altamente heterogêneos, diferentes tipos de células respondem de maneira diversa às condições de cultura, como, por exemplo, no caso de segmentos de caule de Petunia, onde células corticais dão origem a calo, e das células da região vascular originam diretamente pacotes meristemáticos embriogênicos (Handro et al., 1973).

A embriogênese somática é um caso particular de morfogênese, onde a partir de tecidos do explante ou de calo, organizam-se estruturas bipolares semelhantes aos embriões zigóticos. Tais estruturas se originam geralmente de uma célula ou pequeno grupo de células no calo, ou também diretamente a partir de camadas internas ou superficiais num explante. Assim, a embriogênese também pode ser um processo direto ou indireto. $\mathrm{Na}$ embriogênese, as estruturas formadas têm organização nitidamente bipolar (pólos caulinar e radicular), destacando-se com facilidade da massa de tecidos que as originaram. Em geral, o isolamento dos embriões e sua cultura para seu posterior desenvolvimento numa planta nova ocorre em meio de cultura diferente daquele que os induziu.

\subsubsection{Manejo da planta matriz}

Nos últimos anos, vários fatores que afetam o crescimento do explante in vitro têm sido amplamente estudados, incluindo fitorreguladores, luz, temperatura, $\mathrm{pH}$, umidade, gases e presença de microorganismos. Porém, estudos relacionados com requerimentos nutricionais (nutrientes minerais, 
carboidratos, vitaminas e aminoácidos), foram pouco explorados (Leifert et al., 1995).

Segundo Grattapaglia \& Machado (1990), o verdadeiro desafio da cultura de tecidos está no material vegetal em si e na manipulação deste antes de se isolar o explante inicial. Esta manipulação inclui o manejo da planta matriz, pois o estado fisiológico e fitossanitário desta tem grande influência no posterior comportamento da cultura. Os mesmos autores afirmam que a capacidade de regeneração e crescimento in vitro parece estar associado não apenas ao genótipo, mas também à atividade fisiológica na planta matriz, sob o controle de diversos fatores endógenos. Plantas bem nutridas, sem sintomas de deficiência nutricional ou hídrica, em geral fornecem explantes melhores. Bhojwani \& Razdan (1983) destacaram que o estado fisiológico da planta matriz no momento da excisão tem uma influência definitiva na resposta de crescimento, e que para minimizar as flutuações de respostas é recomendado manter as plantas parentais sob condições de casa de vegetação. A manutenção das plantas matrizes em casa de vegetação facilita não somente o controle e manipulação do fotoperíodo, intensidade luminosa e temperatura, mas também o controle do estado nutricional e fitossanitário das plantas (Grattapaglia \& Machado, 1990).

Existe uma grande variedade de estudos relacionados com a micropropagação da cenoura, no entanto, ocorre uma carência de trabalhos que relacionam a influência da origem da planta matriz no posterior processo de morfogênese in vitro. Um aspecto muito importante que envolve a origem da planta matriz, é o estado nutricional da mesma. Entretanto esse aspecto foi pouco abordado nos estudos feitos com cenoura. Os trabalhos referentes à nutrição mineral em cultura de tecido vegetal se restringem a discussões sobre as características do meio de cultura, como os estudos feitos por Song et al. (1981), onde se verificou que a formação de calo em anteras de Oriza sativa cultivadas in vitro foi maior quando a concentração de nitrogênio, fósforo, potássio e cálcio foram reduzidos à metade. 


\section{MATERIAL E MÉTODOS}

\subsection{Obtenção de plantas matrizes com diferentes estados nutricionais}

Os experimentos foram conduzidos no Laboratório de Biotecnologia Agrícola (CEBTEC) do Departamento de Ciências Biológicas, da Escola Superior de Agricultura "Luiz de Queiroz" (ESALQ), no Campus da Universidade de São Paulo (USP), em Piracicaba-SP.

Sementes de cenoura da variedade Brasília de alta seleção (Daucus carota Link), obtida pela empresa Agristar do Brasil Ltda situada em PetrópolisRJ, foram germinadas para obtenção das matrizes usadas neste projeto. A semeadura foi realizada em bandejas de plástico contendo substrato REDMAX - Plug Mix da Eucatex em casa de vegetação. Após a germinação, as plantinhas foram transferidas para vasos de plástico de $2 \mathrm{~L}$ de capacidade usando como substrato areia de granulometria média, adequadamente lavada. As mudas foram então mantidas em casa de vegetação a temperatura ambiente com fotoperíodo de 14 horas de luz e 10 horas de escuro, e regadas apenas com água durante as duas primeiras semanas com o objetivo de amenizar o estresse da aclimatação. Após esse período, as plantas passaram a ser regadas com soluções nutritivas contendo $1 / 4 x, 1 / 2 x, 1 x, 2 x$ e $3 x$ a concentração da solução nutritiva ideal em cálcio $\left(200 \mathrm{mg} \cdot \mathrm{L}^{-1}\right)$, magnésio $\left(48 \mathrm{mg} \cdot \mathrm{L}^{-1}\right)$ e potássio (234mg. $\left.\mathrm{L}^{-1}\right)$, conforme mostra a Tabela 2.

As doses dos nutrientes foram testadas em dezoito repetições por tratamento contendo três plantas por vaso. As soluções nutritivas (Tabela 3) foram preparadas segundo recomendações de Sarruge (1975) e continham os 
nutrientes testados em concentrações supostamente capazes de causar deficiência (Tratamentos 2, 3, 6, 7, 10 e 11), nutrição normal (Tratamento 1) e toxidez (Tratamentos 4, 5, 8, 9, 12 e 13) nutricional nas matrizes (Tabela 2).

As plantas sempre mantidas em casa de vegetação receberam $80 \mathrm{~mL}$ de solução nutritiva por vaso, de três a quatro vezes por semana dependendo da temperatura e umidade nos substratos.

Tabela 2. Tratamento nutricional em $\mathrm{Ca}, \mathrm{Mg}$ e $\mathrm{K}$ realizados em matrizes de Daucus carota e número de amostras coletadas e inoculadas ao longo dos tratamentos, 30, e 60 dias após início da aplicação das soluções nutritivas contendo diferentes níveis dos nutrientes

\begin{tabular}{|c|c|c|c|c|}
\hline & \multirow[t]{2}{*}{ Tratamentos } & \multicolumn{3}{|c|}{ Duração do tratamento (dias) } \\
\hline & & 30 & 45 & 60 \\
\hline 1 & Testemunha (completo) & 18 & 18 & 18 \\
\hline 2 & $1 / 4 \times \mathrm{Ca}\left(50 \mathrm{~g} \mathrm{Ca}^{2+} \cdot \mathrm{L}^{-1}\right)$ & 18 & 18 & 18 \\
\hline 3 & $1 / 2 \times \mathrm{Ca}\left(100 \mathrm{~g} \mathrm{Ca}^{2+} \cdot \mathrm{L}^{-1}\right)$ & 18 & 18 & 18 \\
\hline 4 & $2 \times \mathrm{Ca}\left(400 \mathrm{~g} \mathrm{Ca}^{2+} \cdot \mathrm{L}^{-1}\right)$ & 18 & 18 & 18 \\
\hline 5 & $3 \times \mathrm{Ca}\left(600 \mathrm{~g} \mathrm{Ca}^{2+} \cdot \mathrm{L}^{-1}\right)$ & 18 & 18 & 18 \\
\hline 6 & $1 / 4 \times M g\left(12 g g^{2+} \cdot L^{-1}\right)$ & 18 & 18 & 18 \\
\hline 7 & $1 / 2 \times M g\left(24 g g^{2+} \cdot L^{-1}\right)$ & 18 & 18 & 18 \\
\hline 8 & $2 \times M g\left(96 g^{2+} \cdot L^{-1}\right)$ & 18 & 18 & 18 \\
\hline 9 & $3 \times \operatorname{Mg}\left(144 g g^{2+} \cdot L^{-1}\right)$ & 18 & 18 & 18 \\
\hline 10 & $1 / 4 \times K \quad\left(58,5 \mathrm{~g} \mathrm{~K}^{+} . \mathrm{L}^{-1}\right)$ & 18 & 18 & 18 \\
\hline 11 & $1 / 2 \times K \quad\left(117 \mathrm{~g} \mathrm{~K}^{+} . \mathrm{L}^{-1}\right)$ & 18 & 18 & 18 \\
\hline 12 & $2 \times K \quad\left(468 g^{+} . L^{-1}\right)$ & 18 & 18 & 18 \\
\hline 13 & $3 \times \mathrm{K} \quad\left(702 \mathrm{~g} \mathrm{~K}^{+} . \mathrm{L}^{-1}\right)$ & 18 & 18 & 18 \\
\hline
\end{tabular}

Após início do tratamento com soluções nutritivas, a primeira coleta de explante foi realizada aos 30 dias, das quais dezoito plantas de cada tratamento 
foram coletadas, lavadas, desinfestadas e segmentadas para servirem como explantes. No momento da coleta dos explantes (internódios) foi retirada uma planta inteira de cada vaso, e pesada para obtenção da massa de matéria fresca total. Em seguida estas plantas foram secas em estufa a $65^{\circ} \mathrm{C}$ por sete dias (peso constante), e pesadas para determinação da massa de matéria seca. Utilizandose então de um moinho equipado com peneira de malha de $1 \mathrm{~mm}$, o material seco foi moído e pesado $200 \mathrm{mg}$ por amostra para posterior análise química da constituição em nutrientes.

\subsection{Estabelecimento da cultura de calos}

\subsubsection{Assepsia dos explantes}

Como explantes, foram utilizados segmentos de caule sem gema axilar (internódios) entre terceiras e quartas folhas a partir do ápice das mudas.

O primeiro passo utilizado como método de assepsia, após alguns ensaios preliminares, constituiu em cortar e mergulhar o material coletado em Erlenmeyers contendo água autoclavada. Em seguida, os segmentos foram levados para a mesa de fluxo laminar e transferidos para frascos contendo solução de hipoclorito de sódio comercial $20 \%$ (v/v) acrescido de uma gota de Tween 80 (detergente neutro) e mantidos por aproximadamente 15 minutos. Depois de lavados três vezes em água deionizada autoclavada os explantes foram cortados em tamanhos de aproximadamente $1 \mathrm{~cm}$ de comprimento, sendo desprezadas a extremidades que estiveram em contato com as soluções de desinfestação.

\subsubsection{Calogênese}

Os explantes foram inoculados em meio de cultura de Murashige \& Skoog (1962) (Tabela 4) contendo 1/4X, 1/2X, 1x, 2x e 3x a concentração de $K^{+}$, 
$\mathrm{Ca}^{2+}$ e $\mathrm{Mg}^{2+}$ acrescido de 0,1mg da auxina 2,4-D (ácido 2,4diclorofenoxacético), $30 \mathrm{~g}$ de sacarose e $2,3 \mathrm{~g}$ de Phytagel (Sigma) por litro de meio. $\mathrm{O}$ pH final dos meios foi ajustado para 5,7 com solução de $\mathrm{KOH} 1 \mathrm{~N}$. A esterilização foi realizada em autoclave à temperatura de $120^{\circ} \mathrm{C}$ e pressão de 1 atmosfera por 20 minutos. A concentração e o tipo de regulador de crescimento utilizado foi anteriormente testado, buscando estabelecer um meio de cultura ideal, capaz de inicialmente induzir rápida calogênese e posteriormente a morfogênese. Os frascos contendo os explantes em meio de cultura foram mantidos em sala de crescimento em ausência de luz e temperatura de $25 \pm$ $2^{0} \mathrm{C}$.

A avaliação da calogênese foi feita aos 60 dias após a inoculação com base na massa de matéria fresca e massa de matéria seca dos calos formados por explante.

\subsubsection{Diferenciação celular}

Após a obtenção dos calos, estes foram transferidos para novos meios de cultura de mesma composição (Tabela 4), porém, sem fitorregulador para obter morfogênese. Para a avaliação da diferenciação celular (número de plantas regeneradas/explante) foram usados 90 calos de cada tratamento e

postos à luz com freqüente contagem dos explantes com 30 dias. Após a contagem das plantas estas foram secas também em estufa a $65^{\circ} \mathrm{C}$ por sete dias, e então se determinou a massa de matéria seca.

\subsection{Análise química das plantas}

As análises químicas para a determinação das concentrações de $\mathrm{K}^{+}$, $\mathrm{Ca}^{2+} \mathrm{e} \mathrm{Mg}^{2+}$ presentes nas plantas matrizes coletadas foram feitas nos extratos obtidos pela digestão nítrico-perclórica. O potássio foi quantificado pelo método 
de fotometria de chama de emissão; cálcio e magnésio por espectrofotometria de absorção atômica (Sarruge \& Haag, 1974).

\subsection{Análise estatística}

A análise estatística dos resultados foi feita utilizando-se do sistema para análise estatística SAS e as comparações de médias foram feitas através de teste de Tukey a $5 \%$ de probabilidade. 
Tabela 3. Composição química das diferentes soluções nutritivas (mL.L $\left.{ }^{-1}\right)$ adaptado de Sarruge (1975), aplicadas às plantas matrizes de $D$. carota para testar o efeito nutricional em $\mathrm{Ca}, \mathrm{Mg}$ e $\mathrm{K}$ na calogênese e morfogênese

\begin{tabular}{|c|c|c|c|c|c|c|c|c|c|c|c|c|c|c|}
\hline \multicolumn{15}{|c|}{ TRATAMENTOS } \\
\hline \multirow{3}{*}{\multicolumn{2}{|c|}{$\begin{array}{l}\text { Soluções } \\
\text { estoque }\end{array}$}} & \multicolumn{5}{|c|}{ Cálcio $\left(\mathrm{g} . \mathrm{L}^{-1}\right)$} & \multicolumn{4}{|c|}{ Magnésio (g.L ${ }^{-1}$ ) } & \multicolumn{4}{|c|}{ Potássio (g.L ${ }^{-1}$ ) } \\
\hline & & Test & $1 / 4 \mathrm{X}$ & $1 / 2 x$ & $2 x$ & $3 x$ & $1 / 4 X$ & $1 / 2 x$ & $2 x$ & $3 x$ & $1 / 4 \mathrm{X}$ & $1 / 2$ & $2 x$ & $3 x$ \\
\hline & & 1 & 2 & 3 & 4 & 5 & 6 & 7 & 8 & 9 & 10 & 11 & 12 & 13 \\
\hline $\mathrm{KH}_{2} \mathrm{PO}_{4}$ & $\mathrm{M}$ & 1 & 1 & 1 & 1 & 1 & 1 & 1 & 1 & 1 & 1 & 1 & 1 & 1 \\
\hline $\mathrm{KNO}_{3}$ & M & 5 & 5 & 5 & 5 & 5 & 5 & 5 & 1 & 5 & 0,5 & 2 & 5 & 5 \\
\hline $\mathrm{Ca}\left(\mathrm{NO}_{3}\right)_{2}$ & M & 5 & 1,25 & 2,5 & 5 & 5 & 3,5 & 4 & 5 & 1 & 5 & 5 & 5 & 5 \\
\hline $\mathrm{MgSO}_{4}$ & M & 2 & 2 & 2 & 2 & 2 & 0,5 & 1 & 2 & 2 & 2 & 2 & 2 & 2 \\
\hline $\mathrm{KCl}$ & M & - & - & - & - & - & - & - & 4 & - & - & - & 6 & 12 \\
\hline $\mathrm{CaCl}_{2}$ & M & - & - & - & 5 & 10 & 1,5 & 1 & - & 4 & - & - & - & - \\
\hline $\mathrm{NH}_{4} \mathrm{NO}_{3}$ & M & - & 3,75 & 2,5 & - & - & - & - & - & - & 2,25 & 1,5 & - & - \\
\hline$\left(\mathrm{NH}_{4}\right)_{2} \mathrm{SO}_{4} \mathrm{I}$ & & - & - & - & - & - & 1,5 & 1 & - & - & - & - & - & - \\
\hline $\mathrm{Mg}\left(\mathrm{NO}_{3}\right)_{2}$ & M & - & - & - & - & - & - & - & 2 & 4 & - & - & - & - \\
\hline Micro* & & 1 & 1 & 1 & 1 & 1 & 1 & 1 & 1 & 1 & 1 & 1 & 1 & 1 \\
\hline Fe-EDTA** & & 1 & 1 & 1 & 1 & 1 & 1 & 1 & 1 & 1 & 1 & 1 & 1 & 1 \\
\hline
\end{tabular}

*A solução de micronutrientes tem a seguinte composição (g.L $\left.\mathrm{L}^{-1}\right) \mathrm{H}_{3} \mathrm{BO}_{3}=2,86 ; \mathrm{MnCl}_{2} \cdot 4 \mathrm{H}_{2} \mathrm{O}=1,81 ; \mathrm{ZnCl}_{2}=0,10$; $\mathrm{CuCl}_{2}=0,04 ; \mathrm{H}_{2} \mathrm{MoO}_{4} \cdot \mathrm{H}_{2} \mathrm{O}=0,02$.

** A solução de Fe-EDTA foi preparada segundo Jacobson (1951), dissolvendo-se 26,1g de EDTA em 286mL de NaOH 1N e $24 \mathrm{~g}$ de $\mathrm{FeSO}_{4}$. $7 \mathrm{H}_{2} \mathrm{O}$, arejando-se por 12 horas de escuro e completando-se o volume a 1 litro. 
Tabela 4. Composição do meio de cultura utilizado na indução de calogênese e morfogênese em explantes de $D$. carota, segundo formulação de Murashige \& Skoog (1962)

\begin{tabular}{|c|c|}
\hline Componentes & Concentração (mg/L) \\
\hline \multicolumn{2}{|l|}{ Macronutrientes } \\
\hline $\mathrm{NH}_{4} \mathrm{NO}_{3}$ & 1650 \\
\hline $\mathrm{KNO}_{3}$ & 1900 \\
\hline $\mathrm{CaCl}_{2} \cdot 2 \mathrm{H}_{2} \mathrm{O}$ & 440 \\
\hline $\mathrm{MgSO}_{4} \cdot 7 \mathrm{H}_{2} \mathrm{O}$ & 370 \\
\hline $\mathrm{KH}_{2} \mathrm{PO}_{4}$ & 170 \\
\hline \multicolumn{2}{|l|}{ Micronutrientes } \\
\hline $\mathrm{Na}_{2}$ EDTA . $2 \mathrm{H}_{2} \mathrm{O}$ & 37,3 \\
\hline $\mathrm{FeSO}_{4} \cdot 7 \mathrm{H}_{2} \mathrm{O}$ & 27,8 \\
\hline $\mathrm{KI}$ & 0,83 \\
\hline $\mathrm{H}_{3} \mathrm{BO}_{3}$ & 6,3 \\
\hline $\mathrm{MnSO}_{4} \cdot 4 \mathrm{H}_{2} \mathrm{O}$ & 16,9 \\
\hline $\mathrm{ZnSO}_{4} \cdot 7 \mathrm{H}_{2} \mathrm{O}$ & 8,6 \\
\hline $\mathrm{Na}_{2} \mathrm{Mo}_{4} \cdot 2 \mathrm{H}_{2} \mathrm{O}$ & 0,25 \\
\hline $\mathrm{CuSO}_{4} \cdot 5 \mathrm{H}_{2} \mathrm{O}$ & 0,025 \\
\hline $\mathrm{CoCl}_{2} \cdot 6 \mathrm{H}_{2} \mathrm{O}$ & 0,026 \\
\hline \multicolumn{2}{|l|}{ Vitaminas } \\
\hline Ácido nicotínico & 0,5 \\
\hline Piridoxina . $\mathrm{HCl}$ & 0,5 \\
\hline Tiamina & 0,1 \\
\hline Glicina & 2,0 \\
\hline Mio-inositol & 100 \\
\hline 2,4-D & 0,1 \\
\hline Sacarose & 30000 \\
\hline Phytagel (Sigma) & 2300 \\
\hline
\end{tabular}




\section{RESULTADOS E DISCUSSÃO}

\subsection{Desenvolvimento das plantas matrizes}

Após a germinação das sementes e a murcha das folhas cotiledonares, foi iniciado o processo de molhar as plantas com as soluções nutritivas apropriadas. A manifestação dos sintomas visuais típicos de deficiência para os nutrientes testados não foi observada nas partes aéreas das plantas. Como o objetivo do presente trabalho não depende da ocorrência visual dos sintomas de deficiências nas plantas, as coletas de explantes foram realizadas nos períodos de 30 e 60 dias de tratamento.

Os resultados do efeito dos tratamentos das plantas matrizes com soluções contendo diferentes composições dos nutrientes potássio, cálcio e magnésio (Figuras 3, 4 e 5 e Tabela 5) e no teor destes nutrientes nas matrizes tratadas mostraram diferença quantitativa para todos os níveis de nutrientes testados e duração dos tratamentos (Tabela 5). De maneira geral, o tratamento com determinado nutriente resultou no seu teor na planta matriz que foi diretamente proporcional ao nível do nutriente na solução nutritiva utilizada, exceto nos tratamentos com potássio para 60 dias e com cálcio para 30 dias de duração, onde os teores dos nutrientes foram crescentes nas matrizes até a concentração $2 x$, sugerindo ocorrência de saturação com potássio e cálcio a partir deste nível nas soluções nutritivas. Quanto ao potássio podemos especular algumas razões para estes resultados como por exemplo sobre a possível maturidade da planta quando então se inicia a translocação de nutrientes para as raízes para crescimento e expansão da raiz que forma a 
"cenoura", onde durante a armazenagem ocorre aumento na concentração de açúcares redutores o qual é compensado por um decréscimo correspondente na concentração de potássio e ânions de ácidos orgânicos (Beringer et al., 1986), ou ainda por ter ocorrido à saturação de potássio devido à longa duração do tratamento com elevados teores de potássio. Em cevada o teor de potássio na matéria seca de parte aérea diminuiu das plantas jovens até a maturação, mesmo com a adição de potássio (Leigh et al., 1982). O efeito dilutivo pelo crescimento das plantas juntamente com a baixa translocação do cálcio podem ter contribuído para este resultado.

Antagonismo foi observado para os três nutrientes. O tratamento das matrizes com potássio, tanto para 30 como para 60 dias, provocou redução linear no teor de cálcio e magnésio, a qual foi da ordem de duas vezes para altos níveis de potássio comparados ao tratamento com baixos níveis de potássio (Tabela 5). As matrizes tratadas com cálcio mostraram reduções nos teores de potássio e magnésio que foram mais acentuadas no tratamento de 60 dias de duração. Esta redução, proporcionalmente, foi menor para potássio e maior para magnésio (50\%) em decorrência da amplitude do teor máximo dos dois nutrientes nas matrizes. Já as matrizes tratadas com magnésio, em ambos os períodos apresentaram aumento nos teores de $\mathrm{K}^{+}$e $\mathrm{Ca}^{2+}$ nas baixas concentrações de $\mathrm{Mg}^{2+}$ e diminuição nas maiores concentrações.

Em relação à duração do tratamento, a concentração de potássio na matéria seca das plantas foi crescente, o que poderia ser previsto, dada a maior disponibilidade do nutriente imposta pelos níveis crescentes na solução nutritiva e devido os tecidos terem atingido a maturidade e conseqüentemente terem acumulado maior taxa de matéria seca e reduzido o teor de água.

A natureza uniformemente crescente no ganho de potássio no tratamento de curta duração (30 dias) pode ser decorrente do fato das matrizes estarem sob o efeito do racionamento de nutrientes aplicados durante a germinação e crescimento inicial na obtenção das mudas. Além disto, esta linearidade tanto para tratamento com diferentes níveis de potássio como para 
duração do tratamento pode ser também devido a translocalidade alta do $\mathrm{K}^{+}$, mantendo em qualquer condição, concentração constante na planta. Segundo Mengel \& Kirkby (1987), a alta mobilidade de potássio pela planta inteira em conseqüência da permeabilidade da membrana propicia o transporte do $\mathrm{K}^{+}$em direção as folhas e a redistribuição do potássio das partes mais maduras da planta para as mais jovens. 
Tabela 5. Composição em potássio, cálcio e magnésio ( $\mathrm{mg} /$ planta) das matrizes de cenoura tratadas por 30 e 60 dias com solução nutritiva de Hoagland contendo diferentes níveis destes nutrientes

\begin{tabular}{|c|c|c|c|c|c|c|c|}
\hline \multirow{3}{*}{ Tratamento } & & \multicolumn{6}{|c|}{ Teôres dos nutrientes (mg/planta) } \\
\hline & & \multicolumn{2}{|c|}{$\mathrm{K}^{+}$} & \multicolumn{3}{|c|}{$\mathrm{Ca}^{2+}$} & \multirow{2}{*}{$\begin{array}{r}\mathrm{Mg}^{2+} \\
60\end{array}$} \\
\hline & & 30 & 60 & 30 & 60 & 30 & \\
\hline \multirow{5}{*}{$\mathrm{K}^{+}$} & $1 / 4 \mathrm{X}$ & 50,5 & 52,0 & 22,9 & 18,6 & 5,1 & 4,5 \\
\hline & $1 / 2 X$ & 56,1 & 45,9 & 20,8 & 19,1 & 5,6 & 4,2 \\
\hline & $1 \mathrm{X}$ & 64,3 & 64,3 & 15,6 & 14,8 & 4,3 & 3,8 \\
\hline & $2 X$ & 72,9 & 69,4 & 11,5 & 11,9 & 2,9 & 2,8 \\
\hline & $3 X$ & 82,1 & 66,8 & 8,9 & 6,7 & 2,5 & 2,0 \\
\hline \multirow[t]{3}{*}{ Média } & & 65,2 & 59,7 & 15,9 & 14,2 & 4,1 & 3,5 \\
\hline & $1 / 4 X$ & 79,1 & 57,6 & 9,7 & 4,3 & 5,1 & 3,3 \\
\hline & $1 / 2 X$ & 72,9 & 60,2 & 11,3 & 5,4 & 4,8 & 3,4 \\
\hline \multirow[t]{3}{*}{$\mathrm{Ca}^{2+}$} & $1 X$ & 72,9 & 54,6 & 13,4 & 9,1 & 3,7 & 3,3 \\
\hline & $2 X$ & 70,4 & 56,6 & 18,8 & 12,2 & 3,2 & 3,1 \\
\hline & $3 x$ & 69,9 & 58,1 & 18,0 & 14,0 & 2,9 & 2,2 \\
\hline \multirow[t]{3}{*}{ Média } & & 73,0 & 57,4 & 14,2 & 9,0 & 4,0 & 3,1 \\
\hline & $1 / 4 \mathrm{X}$ & 61,2 & 61,71 & 9,95 & 8,87 & 2,14 & 1,74 \\
\hline & $1 / 2 x$ & 68,34 & 65,28 & 12,25 & 9,75 & 2,86 & 2,74 \\
\hline \multirow[t]{3}{*}{$\mathrm{Mg}^{2+}$} & $1 X$ & 55,59 & 58,65 & 11,9 & 11,77 & 2,97 & 3,59 \\
\hline & $2 X$ & 65,75 & 37,74 & 10,55 & 6,20 & 4,16 & 4,47 \\
\hline & $3 X$ & 58,11 & 70,89 & 12,63 & 8,45 & 6,83 & 7,49 \\
\hline Média & & 57,75 & 58,85 & 11,45 & 9,01 & 3,79 & 4,01 \\
\hline
\end{tabular}



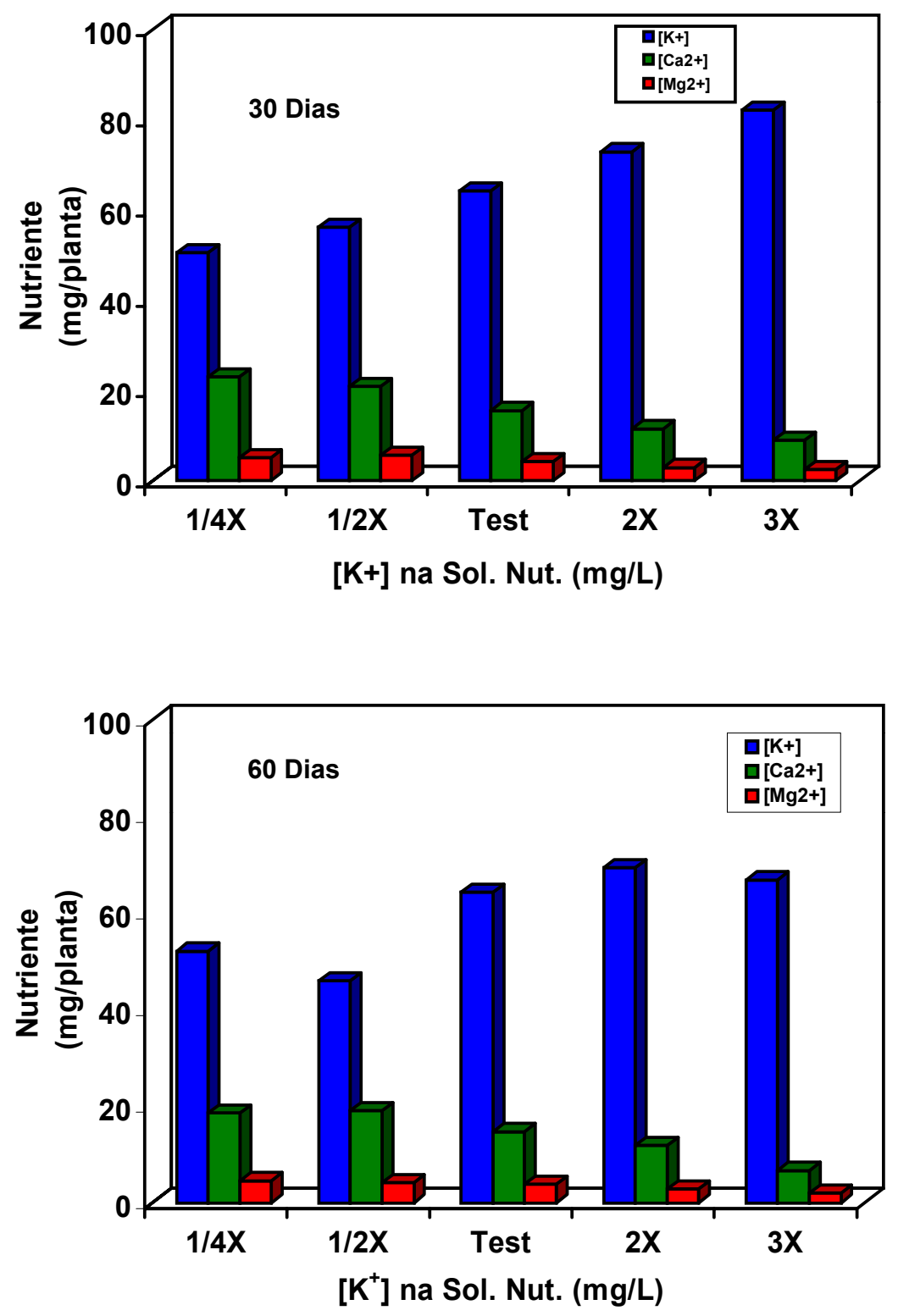

Figura 3 - Efeito do tratamento de plantas matrizes de cenoura por 30 e 60 dias com soluções nutritivas contendo variáveis níveis de potássio no teor de potássio, cálcio e magnésio nas plantas matrizes. 

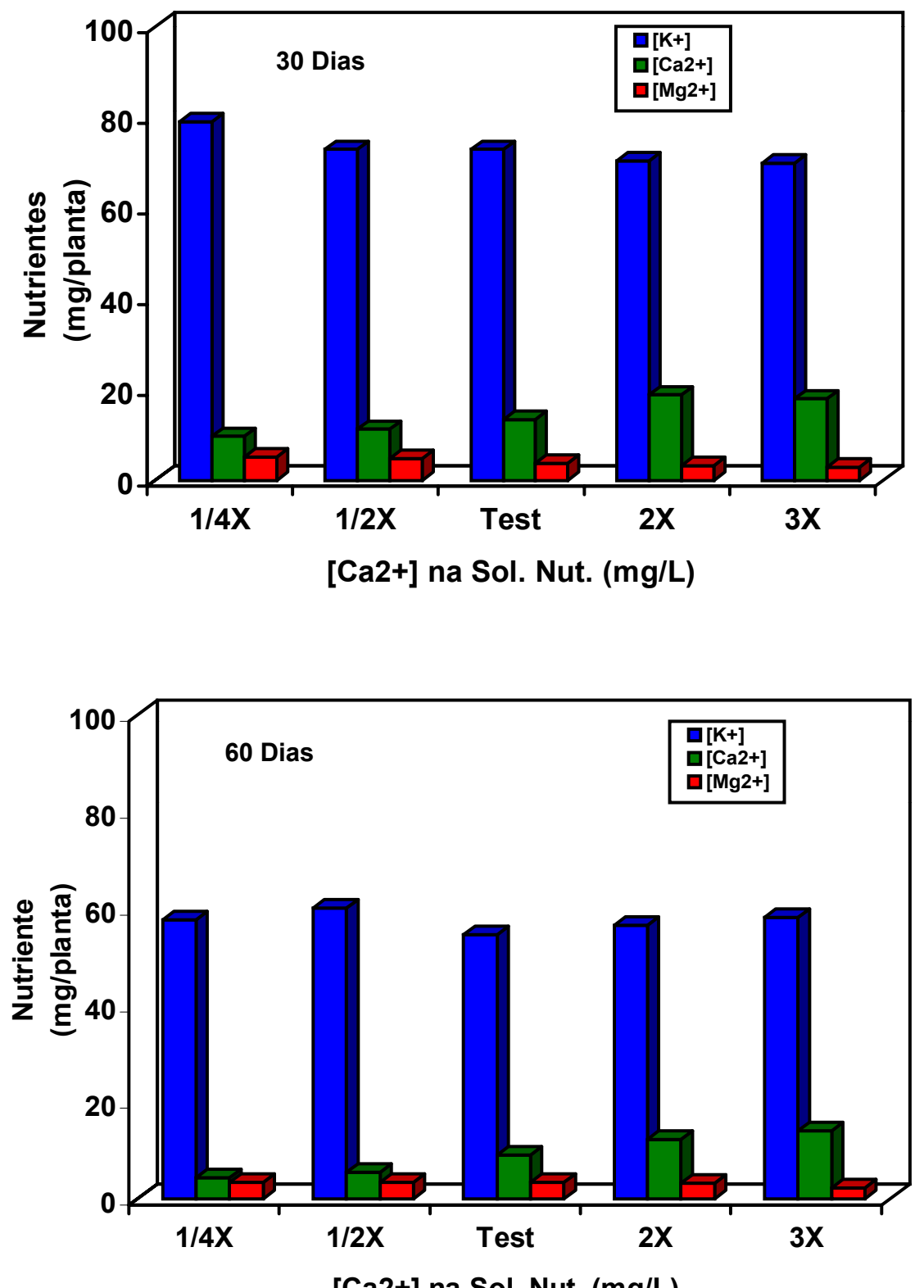

Figura 4 - Efeito do tratamento de plantas matrizes de cenoura por 30 e 60 dias com soluções nutritivas contendo variáveis níveis de cálcio no teor de potássio, cálcio e magnésio nas plantas matrizes. 

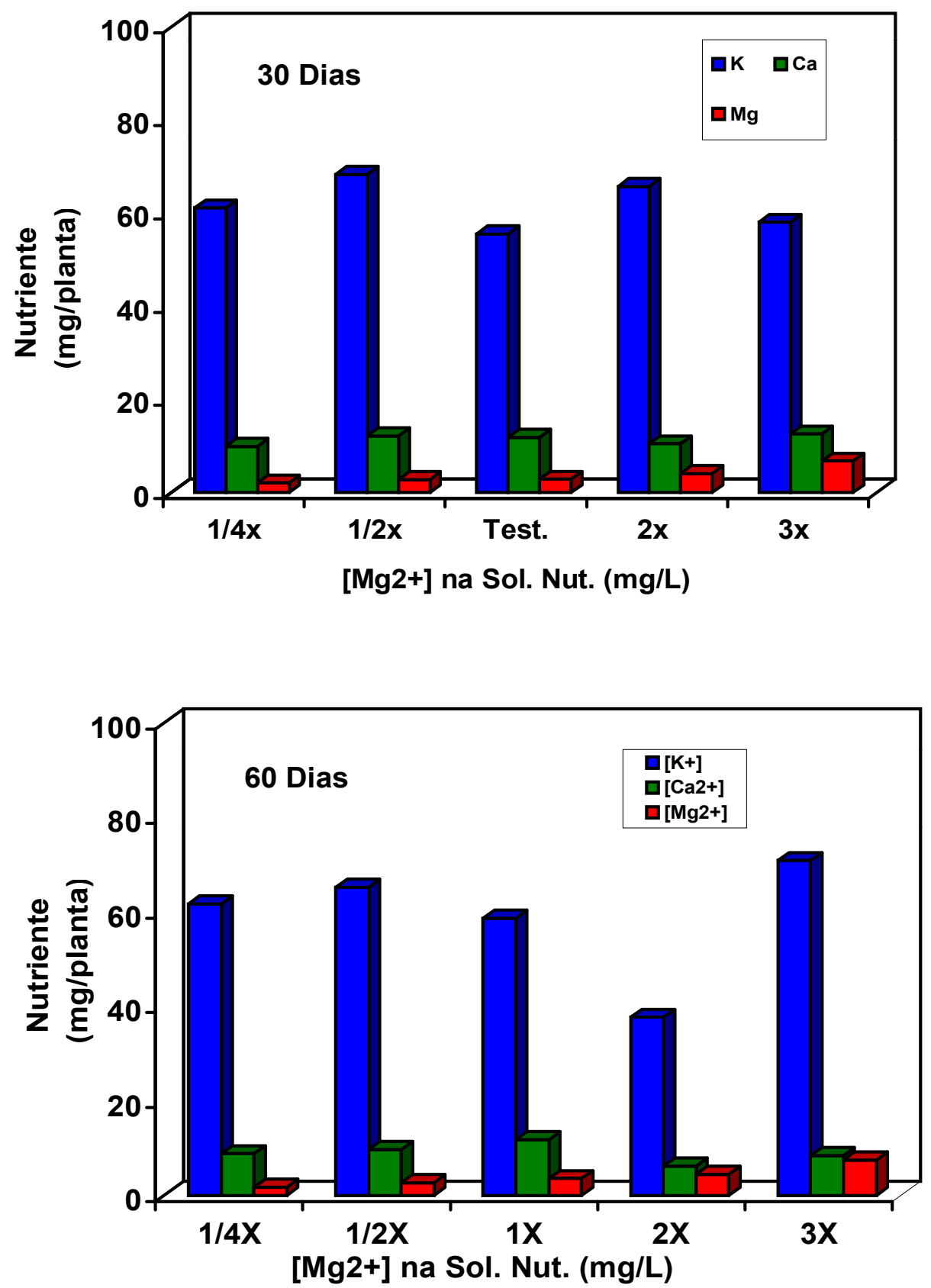

Figura 5 - Efeito do tratamento de plantas matrizes de cenoura por 30 e 60 dias com soluções nutritivas contendo variáveis níveis de magnésio no teor de potássio, cálcio e magnésio nas plantas matrizes. 


\subsection{Calogênese}

A indução de calogênese e crescimento celular (Figura 6) nos explantes de matrizes tratadas foi influenciada pelo tratamento para todos os níveis de potássio na solução nutritiva. A calogênese em massa de matéria fresca de calos foi da ordem de 5 vezes maior aos 60 dias de tratamento, quando comparada com a calogênese aos 30 dias. Por outro lado, em termos de massa de matéria seca de calos, o acúmulo aos 60 dias foi de aproximadamente 2 vezes o acúmulo observado aos 30 dias, conforme mostrado na figura 7 , com a calogênese expressa em índice de multiplicação celular (MS/MF). Quando se compara massa de matéria fresca e massa de matéria seca de calos acumulada, fica evidenciado o efeito da duração do tratamento na capacidade de retenção de água pela massa de calos. Resultados semelhantes foram observados por Borgatto (2000) e Defávari (2000), trabalhando com crisântemo e com Bauhinia forficata, respectivamente.

Como pode ser observado na figura 6 , a calogênese induzida e crescimento celular tanto com base na matéria fresca como na matéria seca aos 30 dias de tratamento, tende a ser inversamente proporcional aos níveis de potássio na solução nutritiva ou ao teor de potássio nos explantes (Tabela $5 \mathrm{e}$ figura 3). A concentração de potássio no meio de cultura não afeta o acúmulo de matéria fresca, entretanto quando se considera a matéria seca, inibição no acúmulo foi observado quando se usou meio de cultura alta concentração de potássio. Embora tenha ocorrido menor calogênese após 30 dias de tratamento, os resultados discutidos mais abaixo mostrando a diferenciação celular, indicam que as células destes tratamentos são mais morfogênicas.

Nos resultados para a calogênese induzida e multiplicação celular após 60 dias de tratamento (Figura 6) pode ser observado que nos explantes das matrizes tratadas com baixos níveis de potássio que contem menores teores de potássio (Figura 3 e tabela 5) apresentaram calogênese em matéria fresca e matéria seca crescente e proporcional até a concentração $2 x$ à concentração de 
potássio no meio de cultura. Nos explantes de matrizes tratadas com nível de potássio igual ao da solução nutritiva de Hoagland (1x na Figura 6), o acúmulo tanto de matéria fresca como de matéria seca de calos foi crescente até somente concentração de potássio no meio de cultura correspondente a do meio MS (1x na Figura 6), e sendo decrescente a partir desta concentração de potássio no meio MS. No entanto para tratamento com 3x a concentração de potássio na solução nutritiva, que resultou na estabilização no teor de potássio nas matrizes (possivelmente explantes com excessivo teor de potássio) a calogênese tanto em matéria fresca como em matéria seca foi linear, mas inversamente proporcional à concentração de potássio no meio de cultura MS, sugerindo que $\mathrm{o}$ alto teor de potássio nos explantes causado pelo longo tratamento com solução nutritiva contendo alta concentração de potássio e a inoculação destes explantes em meio de cultura contendo também alta concentração de potássio, inibe a indução da calogênese. A maior indução de calogênese nos tratamentos por 60 dias é também consistente com esta sugestão. Os teores médios de potássio nas matrizes e conseqüentemente nos explantes aos 60 dias (Tabela 5) são menores que aqueles observados aos 30 dias o que proporcionou maior indução de calogênese principalmente nos explantes inoculados em meios de cultura contendo baixas concentrações de potássio. Este menor teor provavelmente deve-se a translocação de potássio da parte aérea para as raízes para formação da "cenoura".

Entretanto, estatisticamente a diferença na calogênese obtida nos dois períodos (30 e 60 dias) não foi significativa como mostrado na Figura 6.

Os cátions $\mathrm{K}^{+}, \mathrm{Ca}^{2+}$ e $\mathrm{Mg}^{2+}$ absorvidos pelas células vegetais afetam diversos processos biológicos como fotossíntese, oxidações de carboidratos, reações metabólicas, assimilação de nitrogênio e ação gênica. Portanto, pesquisa sobre nutrição mineral de plantas está associada com bioquímica, fisiologia , crescimento e diferenciação celular.

O potássio é ativador de enzimas envolvidas na fotossíntese e respiração, as quais proporcionam esqueleto carbônico para o metabolismo 
celular, estando portanto diretamente relacionado ao balanço carbononitrogênio das plantas, pois o potássio é também necessário para a síntese e ativação da nitrato redutase (Marschner, 1995). A exigência de potássio por enzimas reguladoras da oxidação de carboidratos, como piruvato-quinase (Miller e Evans, 1957; Tomlinson \& Turner, 1973) e 6-fosfofrutoquinase (Läuchli \& Pflüger, 1978), proporciona, na presença de disponibilidade de potássio uma aceleração do metabolismo de carboidratos, promovendo a síntese de maior quantidade de ácidos orgânicos, que em situações de disponibilidade de nitrogênio, regulada também pelo potássio promove a assimilação de amônia, resultando em maior síntese de aminoácidos, proteínas e outros metabólitos celulares, conseqüentemente aumentando o acúmulo de biomassa.

Também $\circ$ metabolismo das poliaminas (agmatina, putrescina, espermina e espermidina) é sabido ser afetado pelo potássio. Plantas e tecidos deficientes em potássio acumulam estas poliaminas (Richard \& Colleman, 1952; Carley et al., 1983; Flores, 1991; Bouchereau et al., 1999). A maioria das investigações relacionando acúmulo de poliaminas e deficiência de potássio tem sido conduzida em folhas e "seedlings" mostrando sintomas de deficiência aguda de potássio (Bouchereau et al., 1999). Entretanto estudos recentes (Geny et al., 1997) mostram que o acúmulo de putrescina em plantas de uva foi severamente influenciado por insuficiência de potássio antes que sintomas visuais de deficiência de potássio nas folhas fossem constatados. Investigações das funções fisiológicas e bioquímicas das poliaminas em plantas apontam de maneira consistente para papel relevante destas substâncias como moduladoras de multiplicação celular, crescimento, desenvolvimento e diferenciação celular (Heby, 1981; Martin \& Morris, 1987). Poliaminas estimulam síntese de DNA, RNA e proteínas nos vegetais, e em elevadas concentrações estão associadas com rápida proliferação de culturas celulares de tabaco e com partes de plantas sofrendo rápida divisão celular, tal como meristema de tomate e batata (Altman et al., 1982; Cohen et al., 1982; Galston, 1983). As poliaminas parecem ser essenciais durante a fase de transição da divisão celular (ciclo 
celular), e é sugerido que a conversão de putrescina para espermidina é importante controlador da taxa de divisão celular.

Este fenômeno parece explicar nossos resultados para 30 dias de tratamento, onde maior indução e crescimento de calos ocorrem quando se utilizou explantes de matrizes tratadas com baixos níveis de potássio na solução nutritiva ou quando explantes foram inoculados em meio de cultura MS contendo as mais baixas concentrações de potássio. Também considerando os resultados da tabela 4 , que mostra o teor de potássio nas matrizes, pode ser inferido que nos explantes contendo os menores teores de potássio ocorre maior indução de calogênese, desde que os níveis de potássio no meio de cultura não seja limitante.

Aparentemente são conflitantes os efeitos do potássio no metabolismo de carboidratos e do nitrogênio encontrados na literatura com os resultados deste trabalho. Baixas concentrações de potássio nas plantas deveria causar menor crescimento e acúmulo de matéria seca pela diminuição na oxidação de carboidrato e assimilação de nitrogênio. Entretanto neste trabalho, maior indução de calogênese e crescimento de calos (massa de matéria seca de calos) foi constatada em explantes de matrizes tratadas com os mais baixos níveis de potássio ou quando os explantes ricos em potássio foram inoculados em meio de cultura contendo as menores concentrações de potássio. Uma hipótese para a explicação dos resultados seria que as poliaminas (também cátions), sintetizadas em maiores concentrações nos tecidos deficientes de potássio, que são sabidas substituírem o potássio em alguns processos fisiológicos demandantes em potássio (Murty et al., 1971; Tachimoto et al., 1992) também substituem o potássio como ativadores das enzimas de fixação de $\mathrm{CO}_{2}$, da oxidação de carboidratos e da assimilação de nitrogênio. As enzimas que catalizam a síntese de putrescina a partir da arginina via agmatine são inibidas por altas concentrações de $\mathrm{K}^{+}$(Regiane et al., 1993) e estimuladas por baixo $\mathrm{pH}$. Considerando o papel relevante do $\mathrm{K}^{+}$na manutenção do alto $\mathrm{pH}$ citoplasmático, parece que quando ocorre o aumento da síntese de putrescina, 
como cátion divalente, significa uma reflexão da homeostase no pH citossólico. Portanto, em plantas deficientes de $\mathrm{K}^{+}$as concentrações de putrescina podem suprir até $30 \%$ do déficit de $\mathrm{K}^{+}$(Murty et al., 1971). De acordo com essa função compensatória de putrescina, a adição externa de putrescina em plantas deficientes de $\mathrm{K}^{+}$aumentaram o crescimento e preveniram sintomas visuais de deficiência de $\mathrm{K}^{+}$(Tachimoto et al., 1992). Também foi observado no presente trabalho, onde plantas tratadas com baixas doses de $\mathrm{K}^{+}$na solução nutritiva a não ocorrência de sintoma visual de deficiência.

Portanto são vários os processos fisiológicos e/ou bioquímicos nos quais o potássio atua ativamente. Provavelmente, um ou mais deles podem ter contribuído para as diferenças na calogênese observada nos explantes originados de plantas matrizes tratadas com diferentes níveis de potássio. No entanto, a caracterização do processo que mais diretamente afeta o comportamento in vitro específico dos explantes oriundos dos diferentes tratamentos, que certamente causaram teores de potássio variados nestes explantes, requer investigações mais específicas tanto nos tecidos dos explantes como no metabolismo das células dos calos gerados por estes explantes. 

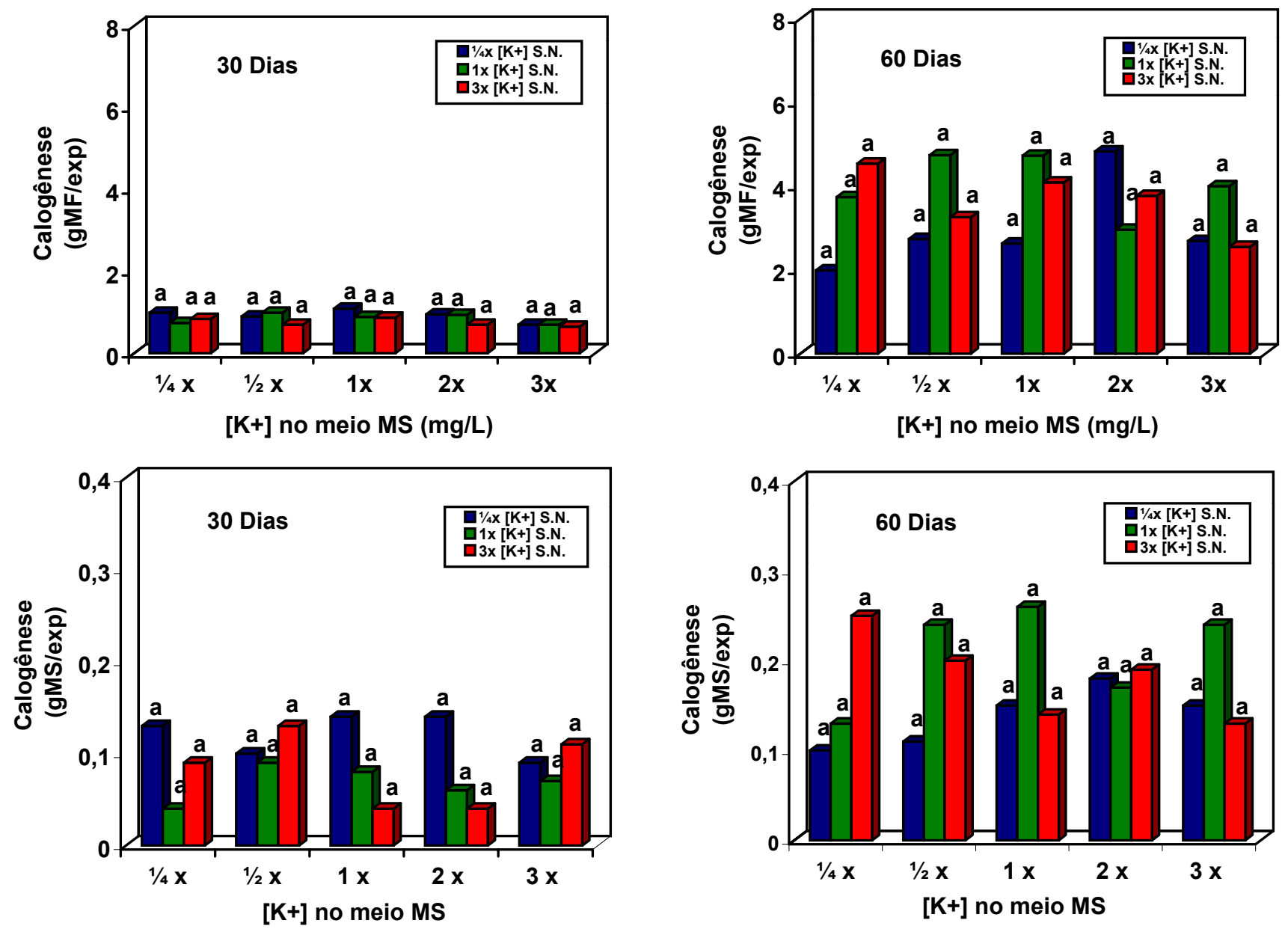

Figura 6 - Calogênese (gramas de MF/explante e MS/explante) em explantes de cenoura tratados por durante 30 e 60 dias com solução nutritiva contendo variáveis níveis de potássio e cultivados em meio de cultura Murashige e Skoog (MS) contendo diferentes concentrações de potássio. 

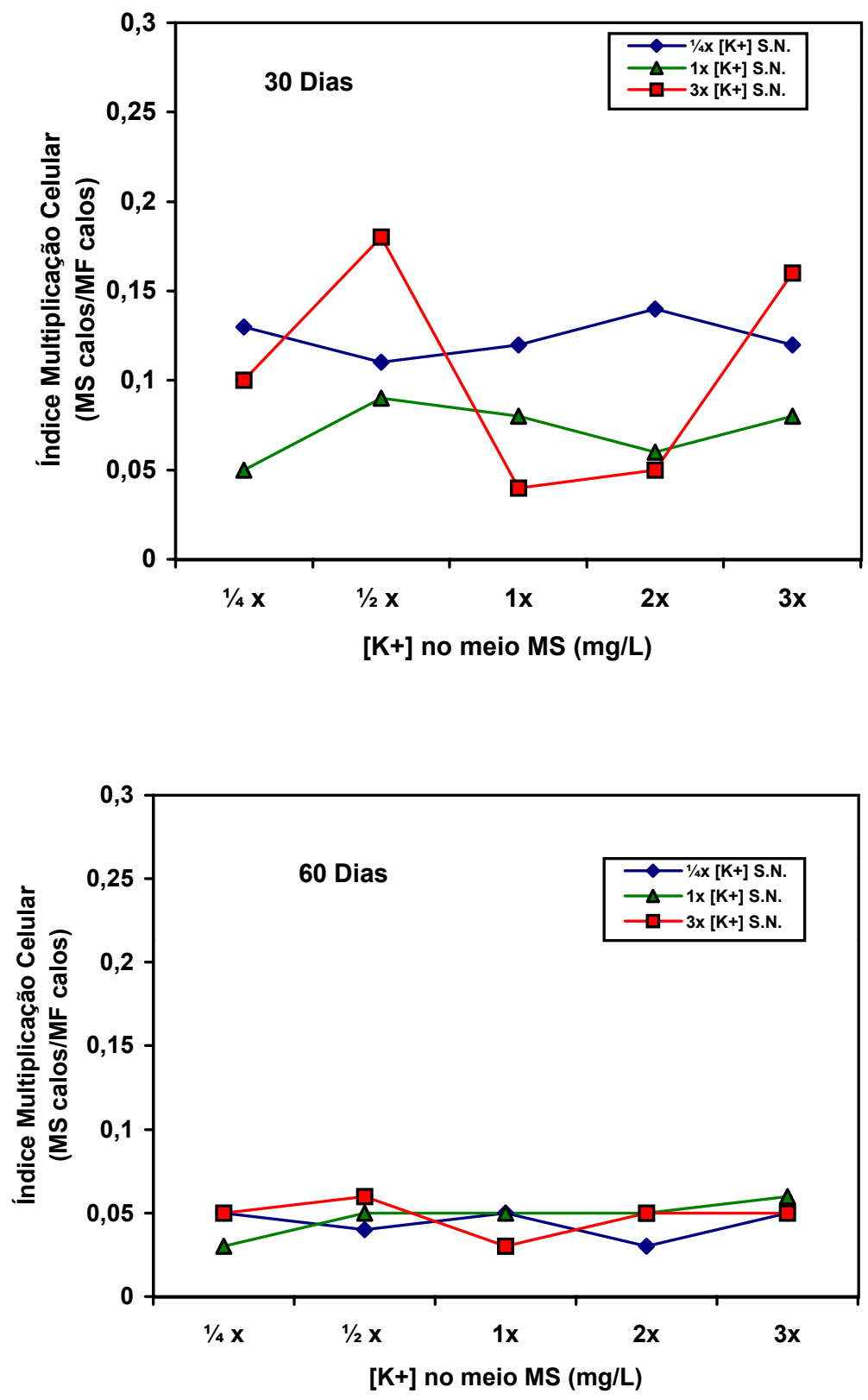

Figura 7- Índice de Multiplicação Celular (MS calos/MF calos) em explantes de matrizes de cenoura tratados por durante $30 \mathrm{e}$ 60 dias com soluções nutritivas contendo variáveis níveis de potássio e cultivados em meio de cultura MS contendo diferentes concentrações de potássio. 


\subsection{Diferenciação celular}

Os resultados obtidos para o efeito dos tratamentos de matrizes de cenoura por durante 30 e 60 dias com diferentes níveis de potássio na solução nutritiva de Hoagland e também no meio de cultura MS na diferenciação celular são apresentados nas Figuras 8 e 9.

Como a diferenciação celular (regeneração de plantas) em cenoura é via embriogênese indireta, a discussão dos resultados de diferenciação será feita com referência a calogênese induzida expressa em massa seca de calos.

Nos tratamentos por 30 dias (Figura 8), nas células dos calos induzidos nos explantes de matrizes tratados com níveis de potássio maiores ou iguais aos níveis da solução nutritiva, a diferenciação celular foi inversamente proporcional aos níveis de potássio na solução nutritiva até a concentração de potássio no meio de cultura igual à concentração do meio Murashige e Skoog. Os resultados para os meios de cultura contendo $2 x$ e $3 x$ a concentração de potássio no meio de cultura foram não conclusivos.

Os tratamentos de matrizes por 60 dias geram nos explantes acúmulo mais alto de calogênese, entretanto, ocorre significativamente menor número de regeneração de plantas (Figura 8). Os resultados expressos em taxa de diferenciação celular (número de plantas/mg massa seca de calos) (Figura 9) evidenciam claramente as características mais morfogênicas das células dos calos produzidos por explantes de matrizes tratadas por 30 dias com potássio. Ficando também evidente nos resultados para 30 dias que baixos níveis de potássio $(1 / 4 \mathrm{X}$ e $1 / 2 \mathrm{X})$ no meio de cultura influenciam negativamente a regeneração de plantas (Figura 8), principalmente nos explantes de matrizes tratadas com os maiores níveis de potássio, e que baixos níveis de potássio na solução nutritiva induzem taxas maiores de regeneração de plantas (Figura 9) nos tratamentos de 60 dias de duração principalmente quando inoculados em meio de cultura contendo baixas concentrações de potássio. 

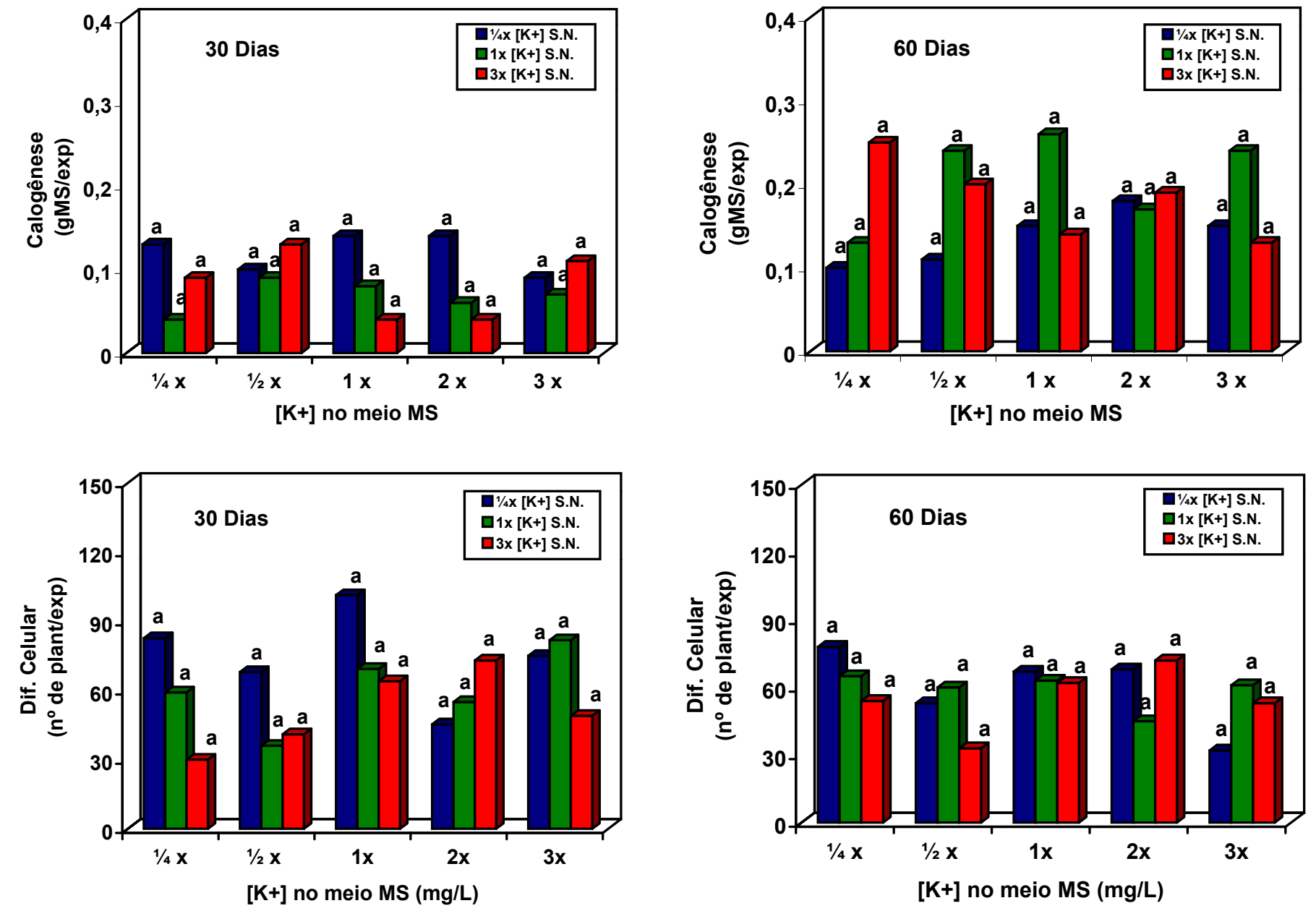

Figura 8 - Calogênese (gramas de MS calos/explante) e diferenciação celular ( $n^{\circ}$ plantas/explante) em explantes de cenoura tratados por durante 30 e 60 dias com solução nutritiva contendo variáveis níveis de potássio e cultivados em meio de cultura Murashige e Skoog (MS) contendo diferentes concentrações de potássio. 
Quando se faz a comparação do acúmulo de massa de matéria seca de calos e diferenciação celular, os resultados mostraram a discrepância entre calogênese e diferenciação celular com relação à duração dos tratamentos e níveis de potássio nas soluções nutritivas. Como mostrado na figura 8, explantes de plantas tratadas por 60 dias com solução nutritiva deram origem à maior formação de calos (em alguns casos até três vezes maior) quando comparado com os explantes dos tratamentos de 30 dias. Entretanto, comportamento oposto foi constatado para os resultados na taxa de diferenciação celular. Taxa mais alta de diferenciação celular (número de plantas/grama de matéria seca de calos) (Figura 9) nas células dos calos dos explantes ocorreu nas matrizes tratadas por 30 dias com solução nutritiva contendo variáveis níveis de potássio onde ocorreu menor calogênese.

$\mathrm{O}$ crescimento e a diferenciação celular in vitro podem ser controlados por vários componentes do meio de cultura. Quando a diferenciação celular é o objetivo de estudo, a atenção é usualmente direcionada aos reguladores de crescimento, entretanto, a nutrição mineral também apresenta um importante papel nesse processo (Ozias-Akins \& Vasil, 1985). Reinert et al. (1967) mostraram que o potássio é essencial na embriogênese de Daucus carota. A concentração de potássio para expressar o máximo potencial embriogênico é maior que a requerida para o crescimento celular em cultura em suspensão de células de cenoura selvagem e, muito do efeito do nitrogênio na embriogênese somática parece depender da concentração de potássio (Brown et al., 1976).

Entre os efeitos fisiológicos e metabólicos conhecidos que a variação no nível celular de potássio pode causar (redução do $\mathrm{CO}_{2}$, oxidação de carboidratos, redução de nitrogênio), a indução da síntese de poliaminas que geralmente ocorre em condições de deficiência de potássio, certamente é o que desempenha papel relevante na diferenciação celular (Richard \& Coleman, 1952, Flores, 1991). Às poliaminas são atribuídas funções estimuladoras de crescimento e de diferenciação celular (Heby, 1981, Marton \& Morris, 1987). Este fenômeno parece claramente explicar nossos resultados pois taxas mais 

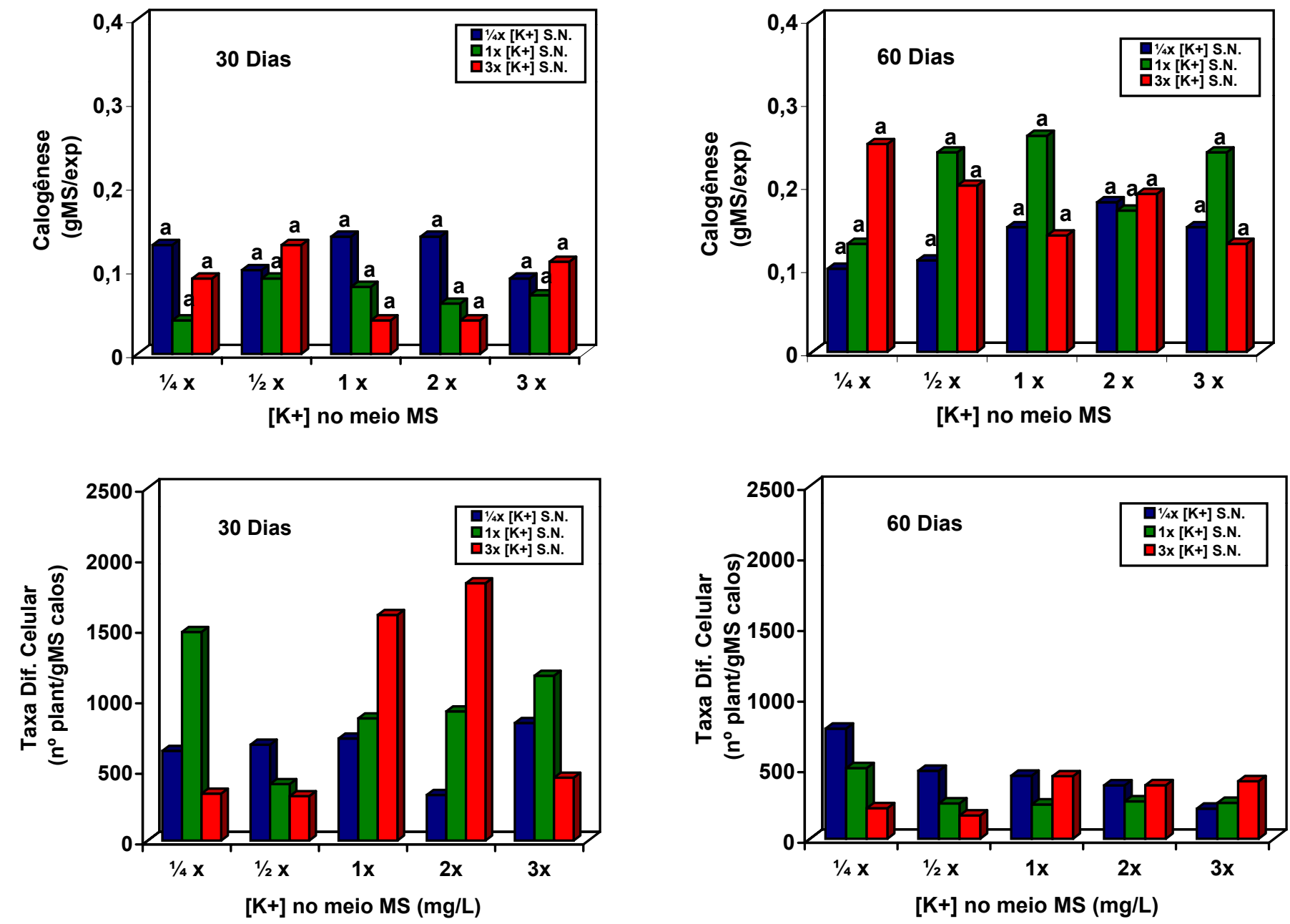

Figura 9 - Calogênese (gramas de MS calos/explante) e taxa de diferenciação celular ( $n^{\circ}$ plantas/g MS calos) em explantes de cenoura tratados por durante 30 e 60 dias com solução nutritiva contendo variáveis níveis de $\mathrm{K}+$ e cultivados em meio de cultura Murashige e Skoog (MS) contendo diferentes concentrações de potássio. 
altas de regeneração de plantas foram obtidas com explantes tratados por 30 dias, quando concentração saturante de potássio não é atingida nas matrizes, mesmo com solução nutritiva contendo $3 x$ a concentração de potássio comparado com a concentração saturante observada ocorrer após 60 dias de tratamento. Esta concentração saturante de potássio induziu maior calogênese e menor diferenciação celular. Também taxa mais alta de diferenciação celular sempre ocorreu nos calos cultivados em meios de cultura contendo níveis mais baixos de potássio.

Plantas sintetizam putrescina a partir das enzimas ornitina descarboxilase (ODC) e arginina descarboxilase (ADC). Kallio \& McCann (1981) \& Metcalf (1978) utilizaram inibidores da biossíntese de poliaminas adifluorometilarginina (DFMA) e a-difluorometilornitina (DFMO), os quais inibem seletivamente e irreversivelmente ADC e ODC, respectivamente, para investigar o papel das poliaminas em culturas embriogênicas de cenoura Daucus carota L. Altman et al. (1982) observou que embora a atividade da ODC tenha associação com rápida proliferação de cultura de células em tabaco e meristemas de tomate e batata e ADC seja responsável pelo aumento de putrescina em folhas de aveia, ainda não é sabido quais das enzimas está envolvida no desenvolvimento do embrião.

Montague et al. (1978) estudaram o metabolismo das poliaminas em culturas embriogênicas de cenoura, sistema modelo no qual células são facilmente induzidas a diferenciar-se formando embriões somáticos com capacidade de formar planta, e elevados níveis de poliaminas e a atividade de $A D C$ foram totalmente correlacionados com a ocorrência da embriogênese nas culturas de cenoura. Segundo os trabalhos dos autores (Halperin \& Wetherell, 1965; Reinert, 1967;) onde utilizaram células de cenoura derivadas de explante de pecíolo mantidas em suspensão celular, na concentração baixa $(0,5 \mathrm{mM})$ no meio, DFMA não reduziu significativamente a embriogênese, mas maiores concentrações do inibidor foram capazes de reduzir e bloquear a indução do embrião. A putrescina restaurou a embriogênese em níveis do controle nos 
tratamentos com $1 \mathrm{mM}$ de DFMA, mas não nas culturas expostas a $5 \mathrm{mM}$ de DFMA. DFMO não inibiu significativamente o desenvolvimento, exceto quando presente em níveis tóxicos, devido à baixa contribuição da ODC para a biossíntese de putrescina. Isto sugere que a ODC não tem papel relevante na embriogênese de cenoura. Experimentos mostram que DFMA pode efetivamente inibir embriogênese em suspensões celulares de células de cenoura. Esta inibição do desenvolvimento pela DFMA, que age pela diminuição da atividade da ADC e baixas concentrações de putrescina nas células, demonstra que putrescina ou espermidina é fator essencial para embriogênese (Russel et al, 1984).

A importância de poliaminas no desenvolvimento foi também demonstrado em tabaco por alteração do metabolismo das poliaminas (Malmberg \& Mcindoo, 1983). Baker et al. (1983) mostrou que a atividade da ornitina carbamiltransferase, uma enzima que leva à biossíntese de arginina, a qual é precursora das poliaminas, aumentou consideravelmente após indução de embriogênese em cenoura. Isto não ocorreu nas culturas que perderam sua capacidade embriogênica, provocando adicional evidência que a arginina, ADC e as poliaminas estão envolvidas na embriogênese de cenoura. Das duas vias alternativas levando a biossíntese das poliaminas nos vegetais, parece preferível a rota envolvendo $A D C$ do que ODC no desenvolvimento embrionário de cenoura. ODC parece associar-se com crescimento proliferativo ou divisão celular nas plantas (Altman et al., 1982; Cohen et al., 1982; Galston, 1983). 


\section{CONCLUSÕES}

Considerando os resultados obtidos neste trabalho com comportamento in vitro (calogênese e diferenciação celular) de explantes, onde se variou a disponibilidade de potássio às matrizes as seguintes afirmações podem ser feitas:

- Condições de baixa disponibilidade de potássio além de causar seu teor baixo nas matrizes, parece condicionar altos teores de cálcio nos tecidos vegetais. Por outro lado, alta disponibilidade de potássio provoca saturação de potássio nos tecidos de matrizes e condiciona reduções maiores que $50 \%$ nos teores de cálcio e magnésio, nos mesmos tecidos;

- A disponibilidade de potássio, que é refletida na composição química em potássio nos tecidos dos explantes afeta tanto a indução de calogênese como a diferenciação celular;

- Tecidos de matrizes tratadas com crescentes níveis de potássio apresentam calogênese que é proporcional aos níveis de potássio utilizado e na decorrente concentração de potássio nos tecidos de matrizes. Entretanto, as células nos calos induzidos em baixa disponibilidade de potássio são mais morfogênicas propiciando maior taxa de regeneração de plantas. Maior taxa de regeneração também é obtida quando se utiliza meio de cultura com concentrações de potássio menores do que aquela do meio de cultura MS; 
- Devido a ocorrência de antagonismo na absorção dos nutrientes e a possibilidade de substituição em algumas funções biológicas dos cátions, se torna difícil a distinção se os efeitos causados, tanto na calogênese como diferenciação celular é devido a concentração de potássio, per se, ou pelo aumento ou redução na concentração dos outros cátions no tecido provocados pelo tratamento com este nutriente em particular. 


\section{REFERÊNCIAS BIBLIOGRÁFICAS}

AHMED, H. A.; ANDREA, M. Effect of heat treatment on acceleration Chrysanthemum multiplication by meristem-tip culture. Acta Horticulturae, n. 212, p. 99-106, 1987.

AITCHISON, P. A.; MACLEOD, A. J.; YEOMAN, M. M. Growth patterns in tissue (callus) cultures. In: STREET, H. E. (Ed.). Plant tissue and cell culture. Oxford: Blackwell Science, 1977. p. 267-287.

ALTMAN, A.; FRIEDMAN, R.; LEVIN, N. Alternative metabolic pathways for polyamine biosynthesis in plant development. Plant Physiology, v. 4, p. 395-408, 1982.

AMMIRATO, P. V. Embryogenesis. In: EVANS, D. A.; SHARP, W. R.; AMMIRATO, P. V. et al. (Ed.). Handbook of plant cell culture. New York: Macmillan, 1983b. v. 1, p. 82-123.

ARMSTRONG, M.J.; KIRKBY, E.A. The influence of humidity on the mineral composition of tomato plants with special reference to calcium distribution. Plant and Soil, v.52, p.427-435, 1979.

ARNON, D. I.; STOUT. P.R. The essenciality ofcertain elements in minute quantity for plants with special reference to copper. Plant Physiology, v. 14 , p. $371-375,1939$. 
ATKINSON, C.J.; MANSFIELD, T.A.; McAINSH, M.R. et al. Interactions of calcium with abscisic acid in the control of stomatal aperture. Biochemie und Physiologie der Pflanzen, v.186, p.333-339, 1990.

AUDRAN, J. C.; DECOUT, E.; DUBOIS, J. et al. Role of temperature as a triggering signal for organogenesis or somatic embryogenesis in wounded leaves of chicory cultured in vitro. Journal of Experimental Botany, v.45, n.281, p.1859-1865, Dec. 1994.

BAKER, S. R.; JONES, L. H.; YON, R. J. Ornithine carbomyltransferase activity and embryogenesis in a carrot cell suspension culture. Phytochemistry, v. 22 , n. 10 , p. 2167-2169, 1983.

BALKE, N.E.; HODGES, T.K. Plasma membrane adenosine triphosphatase of oat roots. Plant Physiology, v.55, p.83-86, 1975.

BANGA, O. Carrot Daucus carota (Umbelliferae). In: SIMMONDS, N. W. (Ed.). Evolution of crop plants. London: Longman, 1976. p.291-293.

BANGERTH, F.; DILLEY, D.R.; DEWEY, D.H. Effect of calcium infusion on internal break-down and respiration of apple fruits. Journal of the American Society for Horticultural Science, v.97, p.679-682, 1972.

BARBedo, A. S. C.; CÂMARA, F. L. A; NAKAGAWA, J. et al. População de plantas, método de colheita e qualidade de sementes de cenoura, cultivar Brasília. Pesquisa Agropecuária Brasileira, v.35, n.8, p.1645-1652, ago. 2000. 
BENNET, R.J.; BREEN, C.M.; BANDU, V.H. A role for $\mathrm{Ca}^{2+}$ in the cellular differentiation of root cap cells: a re-examination of root growth control mechanisms. Environmental and Experimental Botany, v.30, p.515-523, 1990.

BERINGER, H.; KOCH, K.; LINDHAUER, M.G. Sucrose accumulation and osmotic potentials in sugar beet at increasing levels of potassium nutrition. Journal of the Science of Food and Agriculture, v.37, p.211-218, 1986.

BETTI, J. A. Obtenção de material propagativo vegetal testado livre de vírus. In: CROCOMO, O. J.; SHARP, W. R.; MELO, M. (Ed.). Biotecnologia para produção vegetal. Piracicaba: CEBTEC; FEALQ, 1991, p.145-170.

BHOJWANI, S. S. Plant tissue culture: applications and limitations. Amsterdan: Elsevier, 1990. 461p.

BHOJWANI, S. S.; RAZDAN, M. K. Plant tissue culture: theory and practice. Developments in Crop Science, v.5, p.502, 1983.

BLOOM, A. J. Crop acquisition of ammonium and nitrate. In: BOOTE, K. J.; BENNETT, J. M.; SINCLAIR, T. R. et al. (Ed.). Physiology and determination of crop yield. Madison: Agronomy Society of America; Crop Science Society of America, Soil Science Society of America, 1994. p.303309.

BORCHERT, R. $\mathrm{Ca}^{2+}$ as developmental signal in the formation of Ca-oxalate crystal spacing patterns during leaf development in Carya ovata. Planta, v.182, p.339-347, 1990. 
BORGATTO, F. Tratamento de plantas matrizes de Chrysanthemum morifolium

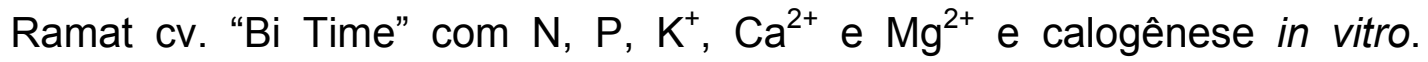
Piracicaba, 2000. 61p. Dissertação (Mestrado) - Escola Superior de Agricultura "Luiz de Queiroz", Universidade de São Paulo.

BOTTRILL, D.E.; POSSINGHAM, J. V.; KRIEDEMANN, P.E. The effect of nutrient deficiencies on photosynthesis and respiration in spinach. Plant and Soil, v.32, p.424-438, 1970.

BOUCHEREAU, A.; AZIZ, A.; LARHER, F. et al. Polyamines and environmental challengers: recent development. Plant Science, v.140, p.103-125, 1999.

BRONNER, R.; JEANNIN, G.; HAHNE, G. Early cellular events during organogenesisand somatic embryogenesis induced on immature zygotic embryos of sunflower (Helianthus annuus). Canadian Journal of Experimental Botany, v.72, p.239-248, 1994.

BROWN, S.; WETHERELL,D. F.; DOUGALL, D. K. The potassium requirement for growth and embryogenesis in wild carrot suspension cultures. Physiologia Plantarum, v.37, p.73-79, 1976.

BRUMMELL, D.A.; HALL, J.L. Rapid cellular responses to auxin and the regulation of growth. Plant Cell and Environment, v.10, p.523-543, 1987.

BUSH, D.S. Calcium regulation in plant cells and its role in signaling. Annual Review of Plant Physiology and Plant Molecular Biology, v.46, p.95122, 1995. 
BUSH, D.S.; BISWAS, A.K.; JONES, R.J. Hormonal regulation of $\mathrm{Ca}^{2+}$ transport in the endomembrane system of the barley aleurone. Planta, v.189, p.507$515,1993$.

BUSSLER, W. Die entwicklung von calcium-mangelsymptomen. Zeitschrift für Pflanzenernährung und Bodenkunde, v.100, p.53-58, 1963.

CALDWELL, C.R.; HAUG, A. Temperature dependence of the barley root plasma membrane-bound $\mathrm{Ca}^{2+}$ and $\mathrm{Mg}^{2+}$-dependent ATPase. Plant Physiology, v. 53, p.117-124, 1981.

CAMMARANO, P.; FELSANI, A ; GENTILE, M. et al. Formation of avtive hybrid 80-S particles from subunits of pea seedlings and mammalian liver ribossomes. Biochimica et Byophisica Acta, v.281, p.625-642, 1972.

CARLEY, E.; WOLOSIUK, R.A.; HERTY, C.M. Regulation of the activation of chloroplast fructose-1,6-bis phosphatase(E.C. 3.1.3.11). Inhibition by epermidine and spermine. Biochemical and Biophysical Research Communication, v. 115, p.707-710, 1983.

CASSELLS, A.L.; BARLASS, M. Environmentally induced changes in the cell walls of tomato leaves in relation to cell and protoplast release. Plant Physiology, v. 37, p. 239-246, 1976.

CHOW, W.S.; BALL, M.C.; NADERSON, J.M. Growth and photosynthetic response of spinach to salinity: implication of $\mathrm{K}^{+}$nutrition for salt tolerance. Australian Journal of Plant Physiology, v.17, p.563-578, 1990.

CLARKSON, D. T.; HANSON, J. B. The mineral nutrition of higher plants. Annual Review of Plant Physiology, v.31, p.239-298, 1980. 
COHEN, E.; HEIMER, Y. M.; MALISARAD, S. Involvement of polyamines in cell division of various plant tissues. Plant Physiology, v.4, p.443-444, 1982.

COLLINS, M.; DUKE, S.H. Influence of potassium-fertilization rate and form on photosynthesis and $\mathrm{N}_{2}$ fixation of alfata. Crop Science, v. 2, p. 481-485, 1981.

COWAN, I.R.; RAVEN, J.A.; HARTUG, W. et al. A possible role for abscisic acid in coupling stomatal conductance and photosynthetic carbon metabolism in leaves. Australian Journal of Plant Physiology, v.9, p.489-498, 1982.

DAVIES, E. Action potentials as multifunctional signals in plants: a unifiying hypothesis to explain apparently disparate wound responses. Plant Cell Environmental, v.10, p.623-631, 1987.

DAVIES, W.J.; MEINZER, F.C. Stomatal responses of plants in drying soil. Biochemie und Physiologie der Pflanzen, v.186, p.357-366, 1990.

DE FOSSARD, R. A. Tissue culture for plant propagators. Armidale: University of New England, 1976. 409p.

DEBERGH, P. C. A. Recent trends in the applications of tissue culture to ornamentals. In: GREEN, C. G.; SOMERS, D. A.; HACKETT, W. P. et al. Plant tissue culture. New York: A. R. Liss, 1990. p. 383-393.

DEFÁVARI, D. Efeito do estado nutricional em $\mathrm{Ca}^{2+}, \mathrm{Mg}^{2+}$ e $\mathrm{K}^{+}$de matrizes de Bauhínia forficata Link na calogênese in vitro. Piracicaba, 2000. 72p. Dissertação (Mestrado) - Escola Superior de Agricultura "Luiz de Queiroz", Universidade de São Paulo. 
EAPEN, S.; GEORGE, L. High frequency plant regeneration throught somatic embryogenesis in finger millet (Eleusine coracana gaertn). Plant Science, v.61, n.1, p.127-130, 1989.

EDWARDS, M.C.; SMITH, G.N.; BOWLING, D. J. F. Guard cells extrude protons prior to stomatal opening - a study using fluorescence microscopy and $\mathrm{pH}$ microelectrodes. Journal of Experimental Botany, v.39, p.15411547, 1988.

EGMOND, F.; BRETELER, H. Nitrate reductase activity and oxalate content of sugar-beet leaves. Netherlands Journal of Agricultural Science, v.20, p.193-198, 1972.

EVANS, D.E.; BRIARS, S.-A.; WILLIAMS, L.E. Active calcium transport by plant cell membranes. Journal of Experimental Botany, v.42, p.285-303, 1991.

EVANS, H. J.; SORGER, G. J. Role of mineral elements with emphasis on the univalent cations. Annual Review of Plant Physiology, v.17, p.47-76, 1966.

EVANS, H. J.; WILDES, R. A. Potassium and its role in enzyme activation. In: COLLOQUIUM OF THE INTERNATIONAL POTASH INSTITUTE, 8.,Bern, 1971. Proceedings. Bern: IPI, 1971. p.13-39.

FELLE, H. Cytoplasmic free calcium in Riccia fluitans L. and Zea mays L.: Interaction of $\mathrm{Ca}^{2+}$ and pH? Planta, v.176, p.248-255, 1988. 
FERNANDO, M.; KULPA, J.; SIDDIQI, M.Y. et al. Potassium-dependent changes in the expression of membrane-associated proteins in barley roots. Plant Physiology, v.92, p.1128-1132, 1990.

FERREIRA, C. M.; HANDRO, W. Some morphogenetic response in leaf explants of Stevia rebaudiana cultured in vitro. Revista Brasileira de Botânica, v.10, p.113-116, 1987.

FERREIRA, C. M.; HANDRO, W. Production, maintenance and plant regeneration from cellsuspension cultures of Stevia rebaudiana (Bert.). Plant Cell Reports, v.7, p.123-126, 1988.

FINK, S. Comparative microscopical studies on the patterns of calcium oxalate distribution in the needles of various conifer species. Botanica Acta, v.104, p.306-315, 1991a.

FINK, S. The micromorphological distribution of bound calcium in needles of Norway spruce (Picea abies (L.) Karst.). New Phytology, v.119, p.33-40, 1991b.

FINK, S. Unusual patterns in the distribution of calcium oxalate in spruce needles and their possible relationships to the impact of pollutants. New Phytology, v.119, p.41-51, 1991c.

FISCHER, E.S.; BUSSLER, W. Effects of magnesium deficiency on carbohydrates in Phaseolus vulgaris. Zeitschrift für Pflanzenernährung und Bodenkunde, v.151, p.295-298, 1988. 
FLOH, E. I. S.; HANDRO, W. Growth and biochemical patterns in tobacco tissues of different ploidy cultured in vitro. Revista Brasileira de Botânica, v.8, p.203-210, 1985a.

FLOH, E. I. S.; HANDRO, W. Variation of histological patterns in tobacco callus during sucessive subcultures. Canadian Journal of Botany, v.63, p.17941800, 1985b.

FLORES, H.E. Changes in polyamine metabolism in response to abiotic stress. In: SLOCUM, R, FLORES, H. E. (Ed.), The biochemistry and physiology of polyamines in plants. Boca Raton: CRC Press, 1991. p.214-225.

GALSTON, A. W.; SAWHNEY, R. K. Polyamines in plant physiology. Plant Physiology, v. 94, p. 406-410, 1983.

GENY, L.; BROQUEDIS,M.; MARTIN_TANGUAY, J. et al. Effects of potassium nutrition on polyamine content of various organs of fruiting cuttings of Vittis vinifera L. Cv. Cabernet Sauvignon. American Journal of Enology and Viticulture, v. 48, p. 85-91, 1997.

GEORGE, E. F.; SHERRINGTON, P. D. Plant propagation by tissue culture: handbook and directory of commercial laboratories. Eversley: Exegetics, 1984. p.693.

GERHARDT, R.; STITT, M.; HELDT, H. W. Subcellular metabolite levels in spinach leaves. Regulation of sucrose synthesis during diurnal alterations in photo-synthetic partitioning. Plant Physiology, v.83, p.399-407, 1987.

GOOR, B.J. van. The role of calcium and cell permeability in the disease blossom end rot of tomatoes. Plant Physiology, v. 21, p.1110-1121, 1966. 
GRATTAPAGLIA, D.; MACHADO, M. A. Micropropagação. In: TORRES, A. C.; CALDAS, L. S. (Ed). Técnicas e aplicações da cultura de tecidos de plantas. Brasília: EMBRAPA, CNPQ, 1990. p.98-169.

GUARDIA, M.D. de la; BENLLOCH, M. Effects of potassium and gibberellic acid on stem growth of whole sunflower plants. Plant Physiology, v. 49, 443448, 1980.

HALPERIN, T.; WETHEREL, D. R. Ammonium requeriment for embryogenesis in vitro. Nature, v.205, p.519-520, 1965.

HALPERIN, W. Population density effects in embryogenesis in carrot cell cultures. Experimental and Cell Reserch, v.48, p.170-173, 1967.

HALPERIN, W.; WETHERELL, D. F. Adventive embryony in tissue cultures od wild carrot Daucus carota. American Journal of Botany, v.51, n.3, p.274, 1964.

HANDRO, H. Effects of some growth regulators on in vitro flowering of Streptocarpus nobilis. Plant Cell Reports, v.2, p.133-136, 1983.

HANDRO, W.; FLOH, E. I. S. Aspectos Básicos do Controle da Morfogênese in vitro. Técnicas e aplicações da cultura de tecidos de plantas. Brasília: ABCTP; EMBRAPA, CNPH, 1990. p.203-212.

HANDRO, W.; RAO, P. S.; HARADA, H. A histological study of the development of buds, roots and embryos in organ cultures of Petunia inflata R. Fries. Annals of Botany, v.37, p.817-821, 1973. 
HANNING, G. E.; CONGER, B. V. Factors influencing somatic embryogenesis from cultured leaf segments of Dactylis golmerata. Journal of Plant Physiology, v.123, p.23-29, 1986.

HARBONE, N. B. Flavonoid and phenylpropanoid patterns in the Umbelliferae. In: HEYWOOD, V. H. (Ed.). The biology and chemistry of the Umbelliferae. New York: Academic Press, 1971. p.293-314.

HEBY, O. Role of polyamines in the control of cell proliferation and differentiation. Differentiation, v.19, p.1-12, 1981.

HECHT-BUCHHOLZ, C. Calcium deficiency and plant ultrastructure. Communications in Soil Science and Plant Analysis, v. 10, p.67-81, 1979.

HEENAN, D. P.; CAMPBELL, L. C. Influence of potassium and manganese on growth und uptake of magnesium by soybeans (Glycine max (L.) Merr. cv Bragg). Plant Soil, v.61, p.447-456, 1981.

HOAGLAND, D. R. Lectures on the inorganic nutrition of plants. Chronica Botanica, Waltham, MA, 1948. p.48-71.

HSIAO, T.C.; LÄUCHLI, A. Role of potassium in plant-water relations. Advances in Plant Nutrition. v.2, p.281-312, 1986.

JESCHKE, W.D.; ATKINS, C.A.; PATE, J.S. Ion circulation via phloem and xylem between rott and shoot of nodulated white lupin. Journal of Plant Physiology, v.117, p.319-330, 1985. 
JONES, J.B. Plant tissue analysis in micronutrients. In: MORTVEDT, J.J; COX, F.R; SHUMAN, L.M et al. (Ed.). Micronutrients in agriculture. 2.ed. Madison:SSSA, 1991. p.477-521. (SSSA. Book Series, 4).

JONES, L. H. P. Mineral components of plant cell walls. American Journal of Clinical Nutrition, v.31, n.10, p.94-98, 1978.

JORNS, A. C.; HECHT-BUCHHOLZ, C.; WISSEMEIER, A. H. Aluminiuminduced callose formation in root tips of Norway spruce (Picea abies (L.) Karst). Zeitschrift für Pflanzenernährung und Bodenkunde, v.154, p.349353, 1991.

KALLIO, A.; MCCANN, P. P. Difluoromethylornithine irreversibly inactivates ornithine decarboxylase of pseudomonas-aeruginosa, but does not inhibit the enzymes of Escheria coli. Biochemical Journal, v.200, n.1, p.69-75, 1981.

KASAI, M.; MUTO, S. $\mathrm{Ca}^{2+}$ pump and $\mathrm{Ca}^{2+} / \mathrm{H}^{+}$antiporter in plasma membrane vesicles isolated by aqueous two phase partitioning from corn leaves. Journal of Membrane Biology, v.114, n.2, p.133-142, 1990.

KAUSS, H. Some aspects of calcium-dependent regulation in plant metabolism. Annual Review of Plant Physiology, v.38, p.47-72, 1987.

KAUSS, H.; WALDMANN, T.; JEBLICK, W. et al. The phytotoxin syringomycin elicits $\mathrm{Ca}^{2+}$-dependent callose synthesis in suspension-cultured cells of Catharanthus roseus. Plant Physiology, v.81, p.134-138, 1991.

KERBAUY, G. B. Plant regeneration of Oncidium varicosum (Orchidaceae) by means of root tip culture. Plant Cell Reports, v.3, p.27-29, 1984a. 
KERBAUY, G. B. Regeneration of protocorm-like bodies through in vitro culture of root tips of Catasetum (Orchidaceae). Zeitschrift für Pflanzenphysiologie, v.113, n.4, p.287-291, 1984b.

KERBAUY, G. B.; PETERS, J. A.; HELL, K. G. Cytokinin-autotrophy and differentiation in tissue cultures of haploid Nicotiana tabacum L. Plant Science, v.45, p.125-132, 1986.

KESSEL, R.H. J.; CARR, A. H. The effect of dissolved oxygen concentration on growth and differentiation of carrot (Daucus carota) tissue. Journal of Experimental Botany, v.23, p.996-1007, 1972.

KINZEL, H. Calcium in the vacuoles and cell walls of plant tissue. Forms of deposition and their physiological and ecological significance. Flora, v.182, p.99-125, 1989.

KIRKBY, E.A.; PILBEAM, D.J. Calcium as a plant nutrient. Plant Cell and Environment, v.7, p.397-405, 1984.

$\mathrm{KOCH}, \mathrm{K} . ;$ MENGEL, K. The influence of the level of potassium supply to young tobacco plants (Nicotiana tabacum L.) on short-term uptake and utilization of nitrate nitrogen. Journal of Science and Food of Agriculture, v.25, p.465471, 1974.

KONNO, H.; YAMAYA, T.; YAMASAKI, Y. et al. Pectic polysaccharide breakdown of cell walls in cucumber roots grown with calcium starvation. Plant Physiology, v.76, p.633-637, 1984. 
KRAUS, J. E.; HANDRO, W.; DIETRICH, S. M. C. Growth, peroxidase activity and protein content in stem and callus tissues from haploid and diploid Nicotiana tabacum plants. Plant Physiology, v.51, p.157-162, 1981.

KREIMER, G.; MELKONIAN, M.; HOLTUM, J. A. M. et al. Stromal free calcium concentration and light-mediated activation of chloroplast fructose-1,6bisphosphatase. Plant Physiology, v.86, p.423-428, 1988.

KRIKORIAN, A. D. Cloning higher plants from aseptically culture tissues and cells. Biological Review, v.57, p.151, May, 1982.

KUIPER, D.; KUIPER, P. J. C. Ca and Mg stimulated ATPases from roots of Plantago lanceolata, Plantago media and Plantago coronopus: Response to alterations of the level of mineral nutrition and ecological significance. Plant Physiology, v.45, p.240-244, 1979.

KUNIEDA, M. K.; KERBAUY, G. B. Formação de gemas em raízes adventícias de couve-flor cultivadas in vitro. Revista Brasileira de Botânica, v.9, p.231-238, 1986.

KURVITS, A.; KIRKBY, E. A. The uptake of nutrients by sunflower plants (Helianthus annuus) growing in a continuous flowing culture system, supplied with nitrate or ammonium as nitrogen source. Zeitschrift für Pflanzenernährung und Bodenkunde, v.143, p.140-149, 1980.

LÄUCHLI, A.; PFLÜGER, R. Potassium transport through plant cell membranes and metabolic role of potassium in plants. In: CONGRESS INTERNATIONAL POTASH INSTITUTE, 11., Bern, 1978. Proceedings. Bern: IPI, 1978. p.111-163. 
LEGGE, R.L.; THOMPSON, E.; BAKER, J.E. et al. The effect of calcium on the fluidity and phase properties of microsomal membranes isolated from postclimacteric Golden Delicious apples. Plant Cell Physiology, v.23, p.161-169, 1982.

LEIFERT, C.; MURPHY, K. P.; LUMSDEN, P. J. Mineral and carbohydrate nutrition of plant cell and tissue culture. Critical Reviews in Plant Sciences, v.14, n.2, p.83-109, 1995.

LEIGH, R. A.; WYN JONES, R. G. A hypothesis relating critical potassium concentration for growth to the distribution and functions of this ion in the plant cell. New Phytology, v.97, p.1-13, 1984.

LEIGH, R. A.; STRIBLEY, D. P.; JONSTON, A. E. How should tissue nutrient concentrations be expressed? In: INTERNATIONAL PLANT NUTRITION COLLOQUIUM, 9., Warwick, 1982. Proceedings. Farnham Royal: CAB, 1982. p.39-44.

LERCHL, D.; HILLMER, S.; GROTHA, R. et al. Ultrastructural observations on CTC-induced callose formation in Riella helicophylla. Botanica Acta, v.102, n.1, p.62-70, Feb. 1989.

LILLO, C. Effects of media components and environmental factors on shoot formation from protoplast derivated calli of Solanum tuberosum. Plant Cell, Tissue and Organ Culture, v.19, p.103-111, 1989.

LIN, D. C.; NOBEL, P. S. Control of photosynthesis by $\mathrm{Mg}^{2+}$. Archives of Biochemistry and Biophysics, v.145, n.2, p.622-632, 1971. 
LONERAGEM, J.F.; SNOWBALL, K. Calcium requirements of plants. Australian Journal of the Agricultural Research, v.20, p.465-478, 1969.

LONERAGEM, J.F.; SNOWBALL, K.; SIMMONS, W.J. Response of plants to calcium concentration in solution culture. Australian Journal of Agricultural Research v.19, p.845-857, 1968.

MALMBERG, R. L.; MCINDOO, J. Abnormal floral development of a tobacco mutant with elevated polyamines levels. Nature, v.305, n.5935, p.623-625, 1983.

MANSFIELD, T.A.; HETHERINGTON, A.M.; ATKINSON, C.J. Some aspects of stomatal physiology. Annual Review of Plant Physiology and Molecular Biology, v.41, p.55-75, 1990.

MARSCHNER, $\mathrm{H}$. Mineral nutrition of higher plants. 2.ed. London: Academic Press, 1995. 889p.

MARSCHNER, H.; CAKMAK, I. High light intensity enhances chlorosis and necrosis in leaves of zinc, potassium, and magnesium deficient bean (Phaseolus vulgaris) plants. Journal of Plant Physiology, v.134, p.308315, 1989.

MARSCHNER, H.; RICHTER, C. Calcium-Transport in Wurzeln von Mais- und Bohnenkeimpflanzen. Plant Soil, v. 40, p.193-210, 1974.

MARTON, L.; MORRIS, D. Molecular and cellular functions of the polyamines. In: McCANN, P. P.; PEGG, A.;.SJOERDSMA, A. (Ed.). Inhibition of polyamine metabolism, San Diego: Academic Press, 1987. p.79-105. 
MAY, R. A.; TRIGIANO R. N. Somatic embryogenesis and plant regeneration from leaves of Dendranthema grandiflora. Journal of the American Society for Horticultural Science, v.116, n 2, p.336-371, 1991.

McSWAIN, B.D.; TSUJIMOTO, H.Y.; ARNON, D.I. Effects of magnesium and chloride ions on light-induced electron transport in membrane fragments from a blue-green alga. Biochimica et Biophysica Acta, v.423, p.313-322, 1976.

MEINZER, F.C.; GRAUTZ, D.A.; SMIT, B. Root signals mediate coordination of stomatal and hydraulic conductance in growing sugarcane. Australian Journal of Plant Physiology, v. 18, p.329-338, 1991.

MENGEL, K.; ARNEKE, W. W. Effect of potassium on the water potential, the osmotic potential, and cell elongation in leaves of Phaseolus vulgaris. Plant Physiology, v. 54, p.402-408, 1982.

MENGEL, K.; HELAL, M. Der Einfluss einer variierten N- und K-Ernährung auf den Gehalt an löslichen Aminoverbindungen in der oberirdischen Pflanzenmasse von Hafer. Zeitschrift für Pflanzenernährung und Bodenkunde, v.120, p.12-20, 1968.

MENGEL, K.; KIRKBY, E.A. Principle of plant nutrition. 4.ed. Bern:International Potash Institute, 1987.655p.

MENGEL, K.; LUTZ, H. J.; BREININGER, M.Th. Auswaschung von Nahrstoffen durch sauren Nebel aus jungen intakten Fichten (Picea abies). Zeitschrift für Pflanzenernährung und Bodenkunde, v.150, p.61-68, 1987. 
METCALF, B. W.; BEY, P.; DANZIN, C. Catalytic irreversible inhibition of mammalian ornithine decarboxylase ( $E$ C $\left.C \quad \begin{array}{lllll}4 & 1 & 1 & 17\end{array}\right)$ by substrate and product analogs. Journal of the American Chemical Society, v.100, n.8, p.2551-2553, 1978.

MICHAEL, G. Uber die aufnahme und verteilung des magnesiums und dessen rolle in der hoheren grunen pflanze. Zeitschrift für Pflanzenernährung und Bodenkunde, v.25, p.65-120, 1941.

MILLER, G.; EVANS, H.J. The influence of salts on pyruvate kinase from tissues of higher plants. Plant Physiology, v.32, p.346-354, 1957.

MINORSKY, P .V.; SPANSWICK, R. M. Electrophysiological evidence for a role for calcium in temperature sensing by roots of cucumber seedlings. Plant Cell and Environment, v. 12, p.137-143, 1989.

MONTAGUE, M. J; ARMSTRONG, T. A.; JAWORSKI, E, G. Polyamine metabolism in embryogenic cells of Daucus carota L. changes in arginine decarbolylase activity. Plant Physiology, v.63, n.2, p.341-345, 1979.

MONTAGUE, M. J.; KOPPENBRINK, J. W.; JAWORSKI, E. G. Polyamine metabolism in embryogenic cells of Daucus carota L. changes in intracellular content and rates of synthesis. Plant Physiology, v.62, n.3, p.430-433, 1978.

MURASHIGE, T. Plant propagation througt tissue culture. Annual Review of Plant Physiology, v.25, p.135-166, 1974. 
MURASHIGE, T.; NAKANO, R. Chromossome complement as a determinant of the morphogenetic potential of tobacco cells. American Journal of Botany, v.54, p.963-970, 1967.

MURASHIGE, T; SKOOG, F. A revised medium for rapid growth and biossays with tobaco tissue cultures. Physiologia Plantarum, v.15, p.473-497, 1962.

MURTY, K.S.; SMITH, T.A.; BOULD, C. The relation between the putrescine content and potassium status of black current leaves. Annals of Botany, v.35, p.687-695, 1971.

NITSOS, R.E.; EVANS, H.J. Effects of univalent cations on the activity of particulate starch synthetase. Plant Physiology, v.44, p.1260-1266, 1969.

OCHOA-ALEJO, N.; CROCOMO, O. J. Influence of ametryn on chromatin activity and on RNA-synthesis in a non-chlorophyllaceous sugarcane cell suspension. Journal of Plant Physiology, v.126, n.4/5, p.355-363, Jan., 1987.

OJA, V.; LAISK, A.; HEBER, U. Light-induced alkalization of the chloroplast stroma in vivo as estimated from the $\mathrm{CO}_{2}$ capacity of intact sunflower leaves. Biochemica et Biophysica Acta, v.849, p.355-365, 1986.

O'NEAL, D.; JOY, K.W. Glutamine synthetase of pea leaves. Divalent cation effects, substrate specificity, and other properties. Plant Physiology, v.54, p.775-779, 1974.

OSMOND, C.B. Acid metabolism in Atriplex. I. Regulation in oxalate synthesis by the apparent excess cation absorption. Australian Journal of Biological Science, v. 20, p.575-587, 1967. 
OUTLAW Jr., W.H. Current concepts on the role of potassium in stomatal movements. Plant Physiology, v.49, p.302-311, 1983.

OZIAS-AKINS, P.; VASIL, I. K. Improved efficiency and normalization of somatic embryogenesis in Triticum aestivum (wheat). Protoplasma, v.117, p.40-44, 1983.

OZIAS-AKINS, P.; VASIL, I.K. Nutrition of plant tissue cultures. In: VASIL, I.K. (Ed.). Cell culture and somatic cell genetics of plants: cell growth, nutrition, cytodifferentiation and cryopreservation. Orlando: Academic Press, 1985. v.1, p.129-147.

PALIYATH, F.; THOMPSON, J.E. Calcium- and calmodulin-regulated breakdown for phospholipid by microsomal membranes from bean cotyledons. Plant Physiology, v.83, p.63-68, 1987.

PARROT, W. A.; WILLIANS, E. G.; HILDEBRAND, D. F. et al. Effect of genotype ono somatic embryogenesis fro immature cotyldeons of soybean. Plant Cell Tissue and Organ Culture, v.42, p.125-132, 1985.

PEOPLES, T.R.; KOCH, D.W. Role of potassium in carbon dioxide assimilation in Mendicago sativa L. Plant Physiology, v.63, p.878-881, 1979.

PFEIFFENSCHNEIDER, Y.; BERINGER, $\mathrm{H}$. Measurement of turgor potential in carrots of different K-nutrition by using the cell pressure probe. In: INTERNATIONAL POTASCH INSTITUTE COLLOQUIUM, 21., Bern, 1989. Proceedings. Farnham Royal: CAB, 1989. p.203-217. 
PFLÜGER, R.; WIEDEMANN, R. Der einflüss monovalenter kationen auf die nitratreduktion von Spinacia oleracea L. Zeitschrift für Pflanzenphysiologie, v.85, p.125-133, 1977.

PIER, P.A.; BERKOWITZ, G.A. Modulation of water stress affects on phtosynthesis by altered leaf $\mathrm{K}^{+}$. Plant Physiology, v.85, p.655-661, 1987.

PIERCE, J. Determinants of substrate specificity and the role of metal in the reaction of ribolosebisphosphate carboxylase/oxygenase. Plant Physiology, v.81, p.943-945, 1986.

PITIMAN, M.G.; MOWAT, J.; NAIR, H. Interactions of processes for accumulation of salt and sugar in barley plants. Australian Journal of Biological Science, v.24, p.619-631, 1971.

PODDAR, K; VISHNOI, R. K.; KOTHARI, S. L. Plant regenerationfrom embryogeniccallus of finger millet Eleusine coracana (L.) Gaertn. On higher concentrations of $\mathrm{NH}_{4} \mathrm{NO}_{3}$ as a replacement of NAA in the medium. Plant Science, v.129, p.101-106, 1997.

POFFENROTH, M.; GREEN, D. B.; TALLMAN, G. Sugar concentrations in guard cells of Vicia faba illuminated with red or blur light. Plant Physiology, v.98, p.1469-1471, 1992.

PREUSSER, E.; KHALIL, F.A.; GORING, H. Regulation of activity of the granule-bond starch synthetase by monovalent cations. Biochemie und Physiologie der Pflanzen, v.176, p.744-752, 1981. 
RAO, I. M.; SHARP, R.E.; BOYER, J.S. Leaf magnesium alters photosynthetic response to low water potentials in sunflower. Plant Physiology, v.84, p.1214-1219, 1987.

RAVEN, J. A.; SMITH, F. A. Nitrogen assimilation and transport in vascular land plants in relation to intracellular $\mathrm{pH}$ regulation. New Phytology, v.76; p.415431, 1976.

REA, P.A.; SANDERS, D. Tonoplast energization: two $\mathrm{H}^{+}$pumps, one membrane. Plant Physiology, v.71, p.131-141, 1987.

RECKMANN, U.; SCHEIBE, R.; RASCHKE, K. Rubisco activity in guard cells compared with the solute requirement for stomatal opening. Plant Physiology, v.92, p.246-253, 1990.

REDDY, A S. N. Calcium: silver bullet in signaling. Plant Science, v.160, p.381404, 2001.

REGGIANE, R.; AURISANO, N.; MATTANA, M. et al. Influence of $\mathrm{K}^{+}$ions on polyamine level in wheat seedlings. Journal of Plant Physiology, v.141, p.136-140, 1993.

REINERT, J. Some aspects of embryogenesis in somatic cells of Daucus carota. Phytomorphology, v.17, n.1/4, p.510, 1967.

RICHARDS, F.J.; COLEMAN, E.G. Occurrence of putrescine in potassium deficient barley. Nature, v.170, p.460-461, 1952. 
RINCON, M.; HANSON, J.B. Controls on calcium ion fluxes in injured or shocked corn root cells: importance of proton pumping and cell membrane potential. Plant Physiology, v.67, p.576-583, 1986.

ROBERTS, D.M.; HARMON, A.C. Calcium-modulated proteins: targets of intracellular calcium signals in higher plants. Annual Review of Plant Physiology and Plant Molecular Biology, v.43, p.375-414, 1992.

ROBLIN, G.; FLEURAT-LESSARD, P.; BONMORT, J. Effects of compounds affecting calcium channels on phytochrome- and blue pigment-mediated pulvinar movements of Cassia fasciculata. Plant Physiology, v.90, p.697$701,1989$.

ROCA, W. M.; RODRIGUES, J.; BELTRAN, J. et al. Tissue culture for the conservation and international excahange of gemplasm. In: FUJIWARA, A. ed. Plant tissue culture 1982. Tokyo: Maruzen, 1982. p.771-772.

RUSSEL, P. F.; MIGNON, G.; LITVAY, J.D. Arginine decarboxylase and polyamines embryogenesis in the wild carrot. Science, v.223, p.1433-1435, 1984.

SÁNCHES-ALONSO, F.; LACHICA, M. Seasonal trends in the elemental content of plum leaves. Communications Soil Science and Plant Analysis, v.18, p.31-43, 1887b.

SANDERS, D.; BROWNLEE, C.; HARPER, J. F. Communicating with calcium. The Plant Cell, v.11, p.691-706, 1999.

SARRUGE, J.R.; HAAG, H. P. Análises químicas em plantas. Piracicaba: ESALQ, 1974. 54p. 
SARRUGE, J.R.; HANDRO, W. Soluções nutritivas. Summa Phytopatologia, v.1, p.231-233, 1975.

SCHMIT, J. -N. Le calcium dans le cellule génératrice en mitose. Estude dans le tube pollinique en germination du Clivia nobilis Lindl. (Amaryllidacee). Comptes Rendus Del Academie Des Sciences Serie III-Sciences De La Vie-Life Sciences, v.293, n.14, p.755-760, 1981.

SCHNYDER, H.; NELSON, C. J.; SPOLLEN, W.G. Diurnal growth of tall fescue leaf blades. II. Dry matter partitioning and carbohydrate metabolism in the elongation zone and adjacent expanded tissue. Plant Physiology, v. 86, p.1077-1083, 1988.

SCHRÖPPEL-MEIER, G.; KAISER, W. M. Ion homeostasis in chloroplasts under salinity and mineral deficiency. I. Soluter concentrations in leaves and chloroplasts from spinach plants under $\mathrm{NaCl}$ or $\mathrm{NaNO}_{3}$ salinity. Plant Physiology, v. 87, p. 822-827, 1988.

SCHUMAKER, K. S.; SZE, H. Solubilization and reconstitution of the oat root vacuolar $\mathrm{H}^{+} / \mathrm{Ca}^{2+}$ exchanger. Plant Physiology, v .92, p. 340-345, 1990.

SCOTT, B. J.; ROBSON, A. D. Distribution of magnesium in wheat (Triticum aestivum L.) in relation to supply. Plant and Soil, v.136, p.183-193, 1991.

SEN GUPTA, A.; BERKOWITZ, G. A.; PIER, P.A. Maintenance of photosynthesis at low leaf water potential in wheat. Plant Physiology, v. 89, p. 1358-1365, 1989. 
SHANNON, M. C.; GRIEVE, C. M. Tolerance of vegetable crops to salinity. Scientia Horticulturae, v.78, p.5-38, 1999.

SIVADAS P.; CHANDRA N.; KOTHARI, S. L. Histology of somatic embryogenesis and shoot bud formation in callus cultures of Finger millet Eleusine coracana (L.) Gaertn. Phytomorphology, v.42, p.203-207, 1992.

SIVADAS, P.; KOTHARI, S. L.; CHANDRA N. High frequency embryoid and plantlet formation in tissue cultures of finger millet (Eleusine coracana L. Gaertn.), Plant Cell Reporter, v.9, p.93-96, 1990.

SKOOG, F.; MILLER, C. O. Chemical regulation of growth and organ formatin in plant tissues cultured in vitro. Symposium of the Society of the Experimental Biology, v.11, p.118-130, 1957.

SONG, H. G.; LI, S. N.; LI, G. R.; YUNG, S. G.; LI, J. W. Studies of increasing the induction rate of callus tissue and pollen plants from anthers of Oryza sativa in vitro. In: SYMPOSIUM ON PLANT TISSUE CULTURE, 11., London, 1981. Proceedings. London: Pitman Publishing, 1981. p.97-106.

SPERRAZZA, J. M.; SPREMULLI, L. L. Quantitation of cation binding to wheat germ ribosomes: influences on subunit association equilibria and ribosome activity. Nucleic Acids Reserch, v.11, p.2665-2679, 1983.

STEER, M. W. The role of calcium in exocytosis and endocytosis in plant cells. Plant Physiology, v. 72, p. 213-220, 1988b.

STEINGRÖVER, E. Storage of osmotically active compounds in the taproot of Daucus carota L., Journal of Experimental Botany, v. 34, p. 425-433, 1983. 
STEWART, G. R.; GRACIA C. A.; HEGARTY, E. E. et al. Nitrate reductase activity and clorophyll content in sun leaves of subtropical Australian closedforest (rainforest) and open-forest communities. Oecologia, v. 82, p. 544$551,1990$.

SUELTER, C.H. Enzymes activated by monovalent cations. Science, v.168, p.789-795, 1970.

SUGIYAMA, T.; NAKYAMA, N.; AKASAWA, T. Structure and function of chloroplast proteins. V. Homotropic effect of bicarbonate in RuBP carboxylase relation and the machanism of activation by magnesium ions. Archives of Biochemistry and Biophysics, 126, 734-745, 1968.

SUSSEX, I. M.; FREI, K. A. Embryoid development in long term tissue cultures of carrot. Phytomorphology, 18: 339-349, 1968.

TACHMOTO, M.; FUKUTOMI, M.; MATSUSHIRO, H. et al. Role of putrescine in Lemna plants under potassium deficiency. Soil Science and Plant Nutrition, v.38, p.307-313, 1992.

TAIZ, L.; ZEIGER, E. Plant physiology. 2.ed. Saunderlands: Sinauer Associates, 1988, 792p.

TALLMAN, G.; ZEIGER, E. Light quality and osmoregulation in Vicia guard cells. Evidence for involvement of three metabolic pathways. Plant Physiology, v.88, p.887-895, 1988.

TESTER, M. Plant ion channels: whole-cell and single-channel studies. New Phytology, v.114, p.305-340, 1990. 
TESTER, M.; BLATT, M.R. Direct measurement of $\mathrm{K}^{+}$channels in thylakoid membranes by incorporation of vesicles into planar lipid bilayers. Plant Physiology, v.91, p.249-252, 1989.

TOMLINSON, J.D.; TURNER, J.F. Pyruvate kinase of higher plants Biochimica et Biophysica Acta, v.39, p.128-139, 1973.

TORRES, A. C.; CALDAS, L. S. Técnicas e aplicações da cultura de tecidos de plantas. Brasília: ABCTP; EMBRAPA, CNPH, 1990. 433p.

TREWAVAS, A.J.; GILROY, S. Signal Transduction in plant cells. Trends in Genetics, v.7, p.356-361, 1991.

TRIGIANO, R. N.; BESTY, R. M.; DIETRICH, J. T. Somatic embryogenesis and plantlet regeneration in Cornus flrorida. Plant Cell Reporter, v.8, p.270-273, 1989.

VERMA, D. C.; DOUGALL, D. K. Influence of carbohydrates on quantitative aspects of growth and embryo formation in wild carrot suspension cultures. Plant Physiology, v.59, p.81-85, 1977.

WEDDING, R.T.; BLACK, M.K. Role of magnesium in the binding of substrate and effectors to phosphoenolpyruvate carboxylase from a CAM plant. Plant Physiology, v.87, p.443-446, 1988.

WU, W., PETERS; J.; BERKOWITZ, G.A. Surface charge-mediated effects of $\mathrm{Mg}^{2+}$ on $\mathrm{K}^{+}$flux across the chloroplast envelope are associated with regulation of stromal $\mathrm{pH}$ and photosynthesis. Plant Physiology, v.97, p.580-587, 1991. 
WYN JONES, R.G., BRADY, C.J. and SPEIRS, J. lonic and osmotic relations in plant cells. In: LAIDMAN, D. L.; WYN JONES, R G. (Ed.). Recent advances in the biochemistry of cereals. London: Academic Press, 1979. p.63-103.

$\mathrm{XU}, \mathrm{N}$;; BEWLEY, J. D. Contracting pattern of somatic and zygotic embryo development in alfafa (Medicago sutiva L.) as revealed by scanning elestron microscopy. Plant Cell Reports, v.11, p.279-284, 1992.

YASUDA, H.; NAKAGIMA, M.; MASUDA, H.; OHWADA, T. Direct formation of heart-shaped embryos from differentiated single carrot cells in culture. Plant Science, v.152, p.1-6, 2000.

YAZAKI, Y.; ASUKAGAWA, N.; ISHIKAWA, Y., et al. Estimation of cytoplasmic free $\mathrm{Mg}^{2+}$ levels and phosphorylation potentials in mung bean root tips in vivo ${ }^{31}$ PNMR spectroscopy. Plant Cell Physiology, v.29, p.919-924, 1988.

ZSOLDOS, F.; KARVALY, B. Effects of $\mathrm{Ca}^{2+}$ and temperature on potassium uptake along roots of wheat, rice and cucumber. Plant Physiology, v. 43, p.326-330, 1978. 
APÊNDICE 
Tabela 1. Efeito do tratamento testemunha (1x) no meio de cultura de matrizes de cenoura Daucus carota L. com diferentes concentrações de potássio no peso da massa fresca e massa secas dos calos formados aos 30 dias após o início do tratamento com solução nutritiva.

\begin{tabular}{lll}
\hline Tratamentos & Massa Fresca (MF) & Massa Seca (MS) \\
\hline $1 \mathrm{x}$ & $0.89 \mathrm{a}$ & $0.08 \mathrm{a}$ \\
$1 / 4 \mathrm{x}$ & $0.74 \mathrm{a}$ & $0.04 \mathrm{a}$ \\
$1 / 2 \mathrm{x}$ & $0.99 \mathrm{a}$ & $0.09 \mathrm{a}$ \\
$2 \mathrm{x}$ & $0.94 \mathrm{a}$ & $0.06 \mathrm{a}$ \\
$3 \mathrm{x}$ & $0.82 \mathrm{a}$ & $0.07 \mathrm{a}$
\end{tabular}

Médias seguidas de mesma letra minúscula entre si pelo teste de Tukey em nivel de $5 \%$ de probabilidade.

Tabela 2. Testemunha (1x) potássio 30 dias ( $\mathrm{n}^{\circ}$ brotos aos 30,45 e 60 dias)

\begin{tabular}{|c|c|c|c|}
\hline \multirow[t]{2}{*}{$\begin{array}{l}\text { Tratamentos } \\
\text { (mg.L }{ }^{-1} \text { de potássio) }\end{array}$} & \multicolumn{3}{|c|}{ Duração do Tratamento (dias) } \\
\hline & 30 & 45 & 60 \\
\hline $1 x$ & $69.33 \mathrm{a}$ & $104.17 \mathrm{a}$ & $88.17 \mathrm{a}$ \\
\hline $1 / 4 X$ & $59.17 \mathrm{a}$ & $45.67 \mathrm{~b}$ & $32.67 \mathrm{a}$ \\
\hline $1 / 2 x$ & $36.00 \mathrm{a}$ & $66.00 \mathrm{ab}$ & $50.25 \mathrm{a}$ \\
\hline $2 x$ & $55.00 \mathrm{a}$ & $36.33 \mathrm{~b}$ & $44.00 \mathrm{a}$ \\
\hline $3 x$ & $81.80 a$ & $77.33 a b$ & $61.25 \mathrm{a}$ \\
\hline
\end{tabular}

Tabela 3. Testemunha (1x) potássio 30 dias (massa seca de brotos aos 30 , 45 e 60 dias)

Tratamentos

(mg. $\mathrm{L}^{-1}$ de potássio) Duração do Tratamento (dias)

\begin{tabular}{llll} 
& 30 & 45 & 60 \\
\hline $1 \mathrm{x}$ & $0,41 \mathrm{a}$ & $0,44 \mathrm{a}$ & $0,45 \mathrm{a}$ \\
$1 / 4 \mathrm{x}$ & $0,25 \mathrm{a}$ & $0,24 \mathrm{bc}$ & $0,21 \mathrm{a}$ \\
$1 / 2 \mathrm{x}$ & $0,45 \mathrm{a}$ & $0,41 \mathrm{ab}$ & $0,20 \mathrm{a}$ \\
$2 \mathrm{x}$ & $0,30 \mathrm{a}$ & $0,16 \mathrm{c}$ & $0,21 \mathrm{a}$ \\
$3 \mathrm{x}$ & $0,47 \mathrm{a}$ & $0,33 \mathrm{ac}$ & $0,24 \mathrm{a}$ \\
\hline
\end{tabular}


Tabela 4. Efeito do tratamento $1 / 4 \mathrm{x}$ no meio de cultura de matrizes de cenoura Daucus carota $\mathrm{L}$. com diferentes concentrações de potássio no peso da massa fresca e massa secas dos calos formados aos 30 dias após o início do tratamento com solução nutritiva.

\begin{tabular}{lll}
\hline Tratamentos & Massa Fresca (MF) & Massa Seca (MS) \\
\hline $1 \mathrm{x}$ & $1.09 \mathrm{a}$ & $0.14 \mathrm{a}$ \\
$1 / 4 \mathrm{x}$ & $0.99 \mathrm{a}$ & $0.13 \mathrm{a}$ \\
$1 / 2 \mathrm{x}$ & $0.90 \mathrm{a}$ & $0.10 \mathrm{a}$ \\
$2 \mathrm{x}$ & $0.95 \mathrm{a}$ & $0.14 \mathrm{a}$ \\
$3 \mathrm{x}$ & $0.70 \mathrm{a}$ & $0.09 \mathrm{a}$
\end{tabular}

Médias seguidas de mesma letra minúscula entre si pelo teste de Tukey em nivel de $5 \%$ de probabilidade.

Tabela 5. Concentração $1 / 4 x$ de potássio 30 dias ( $n^{\circ}$ brotos aos 30, 45 e 60 dias)

\begin{tabular}{llcl}
\hline $\begin{array}{l}\text { Tratamentos } \\
\text { (mg.L }{ }^{-1} \text { de potássio) }\end{array}$ & \multicolumn{3}{c}{ Duração do Tratamento (dias) } \\
\hline & 30 & 45 & 60 \\
$1 \mathrm{x}$ & $101.33 \mathrm{a}$ & $71.25 \mathrm{a}$ & $72.50 \mathrm{a}$ \\
$1 / 4 \mathrm{x}$ & $82.67 \mathrm{a}$ & $50.00 \mathrm{a}$ & $36.25 \mathrm{a}$ \\
$1 / 2 \mathrm{x}$ & $68.00 \mathrm{a}$ & $47.25 \mathrm{a}$ & $40.04 \mathrm{a}$ \\
$2 \mathrm{x}$ & $45.33 \mathrm{a}$ & $68.00 \mathrm{a}$ & $47.67 \mathrm{a}$ \\
$3 \mathrm{x}$ & $75.00 \mathrm{a}$ & $99.33 \mathrm{a}$ & $76.33 \mathrm{a}$ \\
\hline
\end{tabular}

Tabela 6. Concentração 1/4x de potássio 30 dias (massa seca de brotos aos 30, 45 e 60 dias)

\begin{tabular}{llcl}
\hline $\begin{array}{l}\text { Tratamentos } \\
\text { (mg.L }{ }^{-1} \text { de potássio) }\end{array}$ & \multicolumn{3}{c}{ Duração do Tratamento (dias) } \\
\hline & 30 & 45 & 60 \\
$1 \mathrm{x}$ & $0.39 \mathrm{a}$ & $0.34 \mathrm{a}$ & $0.31 \mathrm{a}$ \\
$1 / 4 \mathrm{X}$ & $0.47 \mathrm{a}$ & $0.25 \mathrm{a}$ & $0.24 \mathrm{a}$ \\
$1 / 2 \mathrm{x}$ & $0.40 \mathrm{a}$ & $0.39 \mathrm{a}$ & $0.21 \mathrm{a}$ \\
$2 \mathrm{x}$ & $1.29 \mathrm{a}$ & $0.38 \mathrm{a}$ & $0.28 \mathrm{a}$ \\
$3 \mathrm{x}$ & $0.45 \mathrm{a}$ & $0.38 \mathrm{a}$ & $0.38 \mathrm{a}$ \\
\hline
\end{tabular}


Tabela 7. Efeito do tratamento 3x no meio de cultura de matrizes de cenoura Daucus carota $\mathrm{L}$. com diferentes concentrações de potássio no peso da massa fresca e massa seca dos calos formados aos 60 dias após o início do tratamento com solução nutritiva.

\begin{tabular}{lll}
\hline Tratamentos & Massa Fresca (MF) & Massa Seca (MS) \\
\hline $1 \mathrm{x}$ & $0.87 \mathrm{a}$ & $0.04 \mathrm{a}$ \\
$1 / 4 \mathrm{x}$ & $0.84 \mathrm{a}$ & $0.09 \mathrm{a}$ \\
$1 / 2 \mathrm{x}$ & $0.70 \mathrm{a}$ & $0.13 \mathrm{a}$ \\
$2 \mathrm{x}$ & $0.70 \mathrm{a}$ & $0.04 \mathrm{a}$ \\
$3 \mathrm{x}$ & $0.65 \mathrm{a}$ & $0.11 \mathrm{a}$
\end{tabular}

Médias seguidas de mesma letra minúscula entre si pelo teste de Tukey em nivel de $5 \%$ de probabilidade.

Tabela 8. Concentração $3 x$ de potássio 30 dias ( $n^{\circ}$ brotos aos 30, 45 e 60 dias)

\begin{tabular}{llcl}
\hline $\begin{array}{c}\text { Tratamentos } \\
\text { (mg.L }{ }^{-1} \text { de potássio) }\end{array}$ & \multicolumn{3}{c}{ Duração do Tratamento (dias) } \\
\hline & 30 & 45 & 60 \\
$1 \mathrm{x}$ & $64.00 \mathrm{a}$ & $28.00 \mathrm{a}$ & $85.00 \mathrm{ab}$ \\
$1 / 4 \mathrm{x}$ & $30.00 \mathrm{a}$ & $56.00 \mathrm{a}$ & $44.00 \mathrm{bc}$ \\
$1 / 2 \mathrm{x}$ & $41.00 \mathrm{a}$ & $62.00 \mathrm{a}$ & $52.00 \mathrm{bc}$ \\
$2 \mathrm{x}$ & $73.00 \mathrm{a}$ & $68.00 \mathrm{a}$ & $91.00 \mathrm{a}$ \\
$3 \mathrm{x}$ & $49.00 \mathrm{a}$ & $67.00 \mathrm{a}$ & $41.00 \mathrm{c}$ \\
\hline
\end{tabular}

Tabela 9. Concentração $3 x$ de potássio 30 dias (massa seca de brotos aos 30, 45 e 60 dias)

\begin{tabular}{llll}
\hline $\begin{array}{l}\text { Tratamentos } \\
\text { (mg. L }{ }^{-1} \text { de potássio) }\end{array}$ & \multicolumn{3}{c}{ Duração do Tratamento (dias) } \\
\hline & 30 & 45 & 60 \\
$1 \mathrm{x}$ & $0.36 \mathrm{ab}$ & $0.20 \mathrm{a}$ & $0.45 \mathrm{a}$ \\
$1 / 4 \mathrm{x}$ & $0.20 \mathrm{ab}$ & $0.28 \mathrm{a}$ & $0.26 \mathrm{ab}$ \\
$1 / 2 \mathrm{x}$ & $0.16 \mathrm{~b}$ & $0.37 \mathrm{a}$ & $0.28 \mathrm{ab}$ \\
$2 \mathrm{x}$ & $0.48 \mathrm{a}$ & $0.39 \mathrm{a}$ & $0.40 \mathrm{ab}$ \\
$3 \mathrm{x}$ & $0.16 \mathrm{~b}$ & $0.22 \mathrm{a}$ & $0.20 \mathrm{bc}$ \\
\hline
\end{tabular}


Tabela 10. Efeito do tratamento testemunha (1x) no meio de cultura de matrizes de cenoura Daucus carota L. com diferentes concentrações de potássio no peso da massa fresca e massa seca dos calos formados aos 60 dias após o início do tratamento com solução nutritiva.

\begin{tabular}{lll}
\hline Tratamentos & Massa Fresca (MF) & Massa Seca (MS) \\
\hline $1 \mathrm{x}$ & $4.73 \mathrm{a}$ & $0.26 \mathrm{a}$ \\
$1 / 4 \mathrm{x}$ & $3.74 \mathrm{a}$ & $0.13 \mathrm{a}$ \\
$1 / 2 \mathrm{x}$ & $4.74 \mathrm{a}$ & $0.24 \mathrm{a}$ \\
$2 \mathrm{x}$ & $2.96 \mathrm{a}$ & $0.17 \mathrm{a}$ \\
$3 \mathrm{x}$ & $4.00 \mathrm{a}$ & $0.24 \mathrm{a}$ \\
\hline
\end{tabular}

Médias seguidas de mesma letra minúscula entre si pelo teste de Tukey em nivel de $5 \%$ de probabilidade.

Tabela 11. Testemunha (1x) potássio 60 dias ( $n^{\circ}$ brotos aos 30, 45 e 60 dias)

\begin{tabular}{llll}
\hline $\begin{array}{l}\text { Tratamentos } \\
\text { (mg.L }{ }^{-1} \text { de potássio) }\end{array}$ & \multicolumn{3}{c}{ Duração do Tratamento (dias) } \\
\hline & 30 & 45 & 60 \\
$1 \mathrm{x}$ & $63 \mathrm{a}$ & $77 \mathrm{a}$ & $48 \mathrm{~b}$ \\
$1 / 4 \mathrm{x}$ & $65 \mathrm{a}$ & $37 \mathrm{~b}$ & $27 \mathrm{c}$ \\
$1 / 2 \mathrm{x}$ & $60 \mathrm{a}$ & $59 \mathrm{ab}$ & $37 \mathrm{bc}$ \\
$2 \mathrm{x}$ & $45 \mathrm{a}$ & $71 \mathrm{a}$ & $78 \mathrm{a}$ \\
$3 \mathrm{x}$ & $61 \mathrm{a}$ & $59 \mathrm{ab}$ & $41 \mathrm{~b}$ \\
\hline
\end{tabular}

Tabela 12. Testemunha (1x) potássio 60 dias (massa seca de brotos aos 30, 45 e 60 dias).

\begin{tabular}{llcl}
\hline $\begin{array}{c}\text { Tratamentos } \\
\left(\mathrm{mg} \mathrm{L}^{-1} \text { de potássio) }\right.\end{array}$ & \multicolumn{3}{c}{ Duração do Tratamento (dias) } \\
\hline & 30 & 45 & 60 \\
$1 \mathrm{x}$ & $0.15 \mathrm{a}$ & $0.44 \mathrm{a}$ & $0.21 \mathrm{a}$ \\
$1 / 4 \mathrm{x}$ & $0.24 \mathrm{a}$ & $0.19 \mathrm{a}$ & $0.25 \mathrm{a}$ \\
$1 / 2 \mathrm{x}$ & $0.26 \mathrm{a}$ & $0.42 \mathrm{a}$ & $0.19 \mathrm{a}$ \\
$2 \mathrm{x}$ & $0.11 \mathrm{a}$ & $0.42 \mathrm{a}$ & $0.39 \mathrm{a}$ \\
$3 \mathrm{x}$ & $0.18 \mathrm{a}$ & $0.30 \mathrm{a}$ & $0.24 \mathrm{a}$ \\
\hline
\end{tabular}


Tabela 13. Efeito do tratamento $1 / 4 \mathrm{x}$ no meio de cultura de matrizes de cenoura Daucus carota L. com diferentes concentrações de potássio no peso da massa fresca e massa secas dos calos formados aos 60 dias após o início do tratamento com solução nutritiva.

\begin{tabular}{lll}
\hline Tratamentos & Massa Fresca (MF) & Massa Seca (MS) \\
\hline $1 \mathrm{x}$ & $2.63 \mathrm{a}$ & $0.15 \mathrm{a}$ \\
$1 / 4 \mathrm{x}$ & $1.99 \mathrm{a}$ & $0.10 \mathrm{a}$ \\
$1 / 2 \mathrm{x}$ & $2.74 \mathrm{a}$ & $0.11 \mathrm{a}$ \\
$2 \mathrm{x}$ & $4.83 \mathrm{a}$ & $0.18 \mathrm{a}$ \\
$3 \mathrm{x}$ & $2.69 \mathrm{a}$ & $0.15 \mathrm{a}$ \\
\hline
\end{tabular}

Médias seguidas de mesma letra minúscula entre si pelo teste de Tukey em nivel de $5 \%$ de probabilidade.

Tabela 14. Concentração 1/4x de potássio 60 dias ( $n^{\circ}$ brotos aos 30,45 e 60 dias).

\begin{tabular}{lccc}
\hline $\begin{array}{c}\text { Tratamentos } \\
\text { (mg.L }{ }^{-1} \text { de potássio) }\end{array}$ & \multicolumn{3}{c}{ Duração do Tratamento (dias) } \\
\hline & 30 & 45 & 60 \\
$1 \mathrm{x}$ & $67 \mathrm{a}$ & $56 \mathrm{a}$ & $54 \mathrm{a}$ \\
$1 / 4 \mathrm{X}$ & $78 \mathrm{a}$ & $27 \mathrm{a}$ & $56 \mathrm{a}$ \\
$1 / 2 \mathrm{x}$ & $53 \mathrm{a}$ & $30 \mathrm{a}$ & $29 \mathrm{a}$ \\
$2 \mathrm{x}$ & $68 \mathrm{a}$ & $29 \mathrm{a}$ & $61 \mathrm{a}$ \\
$3 \mathrm{x}$ & $32 \mathrm{a}$ & $27 \mathrm{a}$ & $66 \mathrm{a}$ \\
\hline
\end{tabular}

Tabela 15. Concentração 1/4x de potássio 60 dias (massa seca de bortos aos 30, 45 e 60 dias).

\begin{tabular}{llll}
\hline $\begin{array}{c}\text { Tratamentos } \\
\left(\mathrm{mg} \cdot \mathrm{L}^{-1} \text { de potássio) }\right.\end{array}$ & \multicolumn{3}{c}{ Duração do Tratamento (dias) } \\
\hline & 30 & 45 & 60 \\
1 & $0.14 \mathrm{a}$ & $0.35 \mathrm{a}$ & $0.18 \mathrm{a}$ \\
2 & $0.19 \mathrm{a}$ & $0.18 \mathrm{a}$ & $0.22 \mathrm{a}$ \\
3 & $0.16 \mathrm{a}$ & $0.10 \mathrm{a}$ & $0.15 \mathrm{a}$ \\
4 & $0.30 \mathrm{a}$ & $0.13 \mathrm{a}$ & $0.32 \mathrm{a}$ \\
5 & $0.09 \mathrm{a}$ & $0.22 \mathrm{a}$ & $0.37 \mathrm{a}$ \\
\hline
\end{tabular}


Tabela 16. Efeito do tratamento $3 x$ no meio de cultura de matrizes de cenoura Daucus carota $\mathrm{L}$. com diferentes concentrações de potássio no peso da massa fresca e massa secas dos calos formados aos 60 dias após o início do tratamento com solução nutritiva.

\begin{tabular}{lll}
\hline Tratamentos & Massa Fresca (MF) & Massa Seca (MS) \\
\hline $1 \mathrm{x}$ & $4.09 \mathrm{a}$ & $0.14 \mathrm{a}$ \\
$1 / 4 \mathrm{x}$ & $4.54 \mathrm{a}$ & $0.25 \mathrm{a}$ \\
$1 / 2 \mathrm{x}$ & $3.26 \mathrm{a}$ & $0.20 \mathrm{a}$ \\
$2 \mathrm{x}$ & $3.77 \mathrm{a}$ & $0.19 \mathrm{a}$ \\
$3 \mathrm{x}$ & $2.55 \mathrm{a}$ & $0.13 \mathrm{a}$
\end{tabular}

Médias seguidas de mesma letra minúscula entre si pelo teste de Tukey em nivel de $5 \%$ de probabilidade.

Tabela 17. Concentração $3 x$ de potássio 60 dias ( $n^{\circ}$ brotos aos 30,45 e 60 dias).

\begin{tabular}{llcl}
\hline $\begin{array}{l}\text { Tratamentos } \\
\text { (mg.L }{ }^{-1} \text { de potássio) }\end{array}$ & \multicolumn{2}{c}{ Duração do Tratamento (dias) } \\
\hline & 30 & 45 & 60 \\
$1 \mathrm{x}$ & $62 \mathrm{a}$ & $54 \mathrm{a}$ & $53 \mathrm{a}$ \\
$1 / 4 \mathrm{x}$ & $54 \mathrm{a}$ & $40 \mathrm{a}$ & $54 \mathrm{a}$ \\
$1 / 2 \mathrm{x}$ & $33 \mathrm{a}$ & $36 \mathrm{a}$ & $31 \mathrm{a}$ \\
$2 \mathrm{x}$ & $72 \mathrm{a}$ & $71 \mathrm{a}$ & $52 \mathrm{a}$ \\
$3 \mathrm{x}$ & $53 \mathrm{a}$ & $69 \mathrm{a}$ & $43 \mathrm{a}$ \\
\hline
\end{tabular}

Tabela 18. Concentração 3x de potássio 60 dias (massa seca de brotos aos 30, 45 e 60 dias).

\begin{tabular}{llll}
\hline $\begin{array}{l}\text { Tratamentos } \\
\text { (mg. } \text { L }^{-1} \text { de potássio) }\end{array}$ & \multicolumn{3}{c}{ Duração do Tratamento (dias) } \\
\hline & 30 & 45 & 60 \\
$1 \mathrm{x}$ & $0.19 \mathrm{a}$ & $0.24 \mathrm{a}$ & $0.42 \mathrm{a}$ \\
$1 / 4 \mathrm{x}$ & $0.19 \mathrm{a}$ & $0.27 \mathrm{a}$ & $0.28 \mathrm{a}$ \\
$1 / 2 \mathrm{x}$ & $0.10 \mathrm{a}$ & $0.16 \mathrm{a}$ & $0.23 \mathrm{a}$ \\
$2 \mathrm{x}$ & $0.20 \mathrm{a}$ & $0.45 \mathrm{a}$ & $0.32 \mathrm{a}$ \\
$3 \mathrm{x}$ & $0.19 \mathrm{a}$ & $0.40 \mathrm{a}$ & $0.24 \mathrm{a}$ \\
\hline
\end{tabular}

